Cochrane Database of Systematic Reviews

\title{
Allergen injection immunotherapy for seasonal allergic rhinitis
} (Review)

Calderon MA, Alves B, Jacobson M, Hurwitz B, Sheikh A, Durham S

Calderon MA, Alves B, Jacobson M, Hurwitz B, Sheikh A, Durham S.

Allergen injection immunotherapy for seasonal allergic rhinitis.

Cochrane Database of Systematic Reviews 2007, Issue 1. Art. No.: CD001936.

DOI: 10.1002/14651858.CD001936.pub2.

www.cochranelibrary.com 
TABLE OF CONTENTS

HEADER 1

ABSTRACT

PLAIN LANGUAGE SUMMARY

BACKGROUND

OBJECTIVES

METHODS

RESULTS

Figure 1.

DISCUSSION

AUTHORS' CONCLUSIONS

ACKNOWLEDGEMENTS

REFERENCES

CHARACTERISTICS OF STUDIES

DATA AND ANALYSES

Analysis 1.1. Comparison 1 Active versus placebo, Outcome 1 Symptom score.

Analysis 1.2. Comparison 1 Active versus placebo, Outcome 2 Medication score.

Analysis 1.3. Comparison 1 Active versus placebo, Outcome 3 Symptom and medication.

Analysis 1.4. Comparison 1 Active versus placebo, Outcome 4 Nasal symptom.

Analysis 1.5. Comparison 1 Active versus placebo, Outcome 5 Bronchial symptom.

Analysis 1.6. Comparison 1 Active versus placebo, Outcome 6 Ocular symptom.

Analysis 1.7. Comparison 1 Active versus placebo, Outcome 7 IgG.

Analysis 1.8. Comparison 1 Active versus placebo, Outcome 8 IgG-4.

Analysis 1.9. Comparison 1 Active versus placebo, Outcome 9 Rhinoconjunctivitis Quality of Life score. ADDITIONAL TABLES

WHAT'S NEW

HISTORY

CONTRIBUTIONS OF AUTHORS

DECLARATIONS OF INTEREST

INDEX TERMS 
[Intervention Review]

\section{Allergen injection immunotherapy for seasonal allergic rhinitis}

Moises A Calderon ${ }^{1}$, Bernadette Alves ${ }^{2}$, Mikila Jacobson ${ }^{3}$, Brian Hurwitz ${ }^{4}$, Aziz Sheikh ${ }^{5}$, Stephen Durham ${ }^{6}$

1Department of Allergy and Respiratory Medicine, Royal Brompton Hospital, London, UK. 2Brighton and Hove City PCT, Brighton, UK. ${ }^{3}$ Allergy and Clinical Immunology, Imperial College, South Kensington Campus, London, UK. ${ }^{4}$ King's College London, London, UK. ${ }^{5}$ Division of Community Health Sciences: GP section, The University of Edinburgh, Edinburgh, UK. ${ }^{6}$ Department of Allergy and Respiratory Medicine, Royal Brompton Hospital, London, UK

Contact address: Moises A Calderon, Department of Allergy and Respiratory Medicine, Royal Brompton Hospital, Imperial College School of Medicine at the National Heart and Lung Institute, London, SW3 6LY, UK. m.calderon@imperial.ac.uk.

Editorial group: Cochrane ENT Group

Publication status and date: Edited (no change to conclusions), published in Issue 1, 2009.

Citation: Calderon MA, Alves B, Jacobson M, Hurwitz B, Sheikh A, Durham S. Allergen injection immunotherapy for seasonal allergic rhinitis. Cochrane Database of Systematic Reviews 2007, Issue 1. Art. No.: CD001936. DOI: 10.1002/14651858.CD001936.pub2.

Copyright @ 2009 The Cochrane Collaboration. Published by John Wiley \& Sons, Ltd.

\section{A B S T R A C T}

\section{Background}

Allergic rhinitis is the most common of the allergic diseases. Despite improved understanding of the pathophysiology of allergic rhinitis and advances in its pharmacological treatment, its prevalence has increased worldwide. For patients whose symptoms remain uncontrolled despite medical treatment, allergen injection immunotherapy is advised. An allergen-based treatment may reduce symptoms, the need for medication and modify the natural course of this disease.

\section{Objectives}

To evaluate the efficacy and safety of subcutaneous specific allergen immunotherapy, compared with placebo, for reducing symptoms and medication requirements in seasonal allergic rhinitis patients.

\section{Search methods}

We searched the Cochrane Ear, Nose and Throat Disorders Group Trials Register, the Cochrane Central Register of Controlled Trials (CENTRAL) (The Cochrane Library, Issue 1 2006), MEDLINE (1950 to 2006), EMBASE (1974 to 2006), Pre-MEDLINE, KOREAMED, INDMED, LILACS, PAKMEDINET, Scisearch, $m R C T$ and the National Research Register. The date of the last search was February 2006.

\section{Selection criteria}

All studies identified by the searches were assessed to identify randomised controlled trials involving participants with symptoms of seasonal allergic rhinitis and proven allergen sensitivity, treated with subcutaneous allergen specific immunotherapy or corresponding placebo.

\section{Data collection and analysis}

Two independent authors identified all studies reporting double-blind, placebo controlled randomised trials of specific immunotherapy in patients with seasonal allergic rhinitis due to tree, grass or weed pollens. Two authors independently performed quality assessment of studies. Data from identified studies were abstracted onto a standard extraction sheet and subsequently entered into RevMan 4.2.8. Analysis was performed using the Standardised Mean Difference (SMD) method and a random-effects model; $\mathrm{P}$ values < 0.05 were considered statistically significant. The primary outcome measures were symptom scores, medication use, quality of life and adverse events. 


\section{Main results}

We retrieved 1111 publications of which 51 satisfied our inclusion criteria. In total there were 2871 participants (1645 active, 1226 placebo), each receiving on average 18 injections. Duration of immunotherapy varied from three days to three years. Symptom score data from 15 trials were suitable for meta-analysis and showed an overall reduction in the immunotherapy group (SMD $-0.73(95 \% \mathrm{Cl}-0.97$ to $-0.50, \mathrm{P}$ $<0.00001)$ ). Medication score data from 13 trials showed an overall reduction in the immunotherapy group (SMD of $-0.57(95 \% \mathrm{Cl}-0.82$ to $-0.33, p<0.00001)$ ). Clinical interpretation of the effect size is difficult. Adrenaline was given in $0.13 \%$ ( 19 of 14085 injections) of those on active treatment and in $0.01 \%$ ( 1 of 8278 injections) of the placebo group for treatment of adverse events. There were no fatalities.

\section{Authors' conclusions}

This review has shown that specific allergen injection immunotherapy in suitably selected patients with seasonal allergic rhinitis results in a significant reduction in symptom scores and medication use. Injection immunotherapy has a known and relatively low risk of severe adverse events. We found no long-term consequences from adverse events.

\section{PLAIN LANGUAGE SUMMARY}

\section{Immunotherapy by allergen injections for seasonal allergic rhinitis ('hay fever')}

Seasonal allergic rhinitis ('hay fever') is a global health problem and its prevalence has increased considerably in the last two decades. Treatment includes allergen avoidance, drugs such as antihistamine tablets and nasal sprays, and immunotherapy (vaccination). For those patients whose symptoms remain uncontrolled despite drug treatment, specific allergen immunotherapy (SIT) is advised.

Specific allergen immunotherapy is most commonly administered as subcutaneous (under the skin) injections by specialists requiring a building-up period followed by a maintenance period of three to five years. Immunotherapy may also be delivered by the oral, nasal or sublingual route and these will be studied in separate Cochrane reviews, as will immunotherapy for perennial (all year round) allergic rhinitis. In this review we aimed to evaluate the efficacy and safety of injection immunotherapy, compared with placebo, for reducing symptoms and the need for medication.

We identified randomised, double-blind, placebo controlled trials of specific allergen immunotherapy in patients with seasonal allergic rhinitis due to tree, grass or weed pollens. Fifty-one studies satisfied our inclusion criteria. In total there were 2871 participants (1645 in the treatment groups and 1226 in the placebo), each receiving on average 18 injections. The duration of treatment varied from three days to three years.

This review has shown that injection immunotherapy in suitably selected patients with hay fever results in significant reductions in symptom scores and medication use. Injection immunotherapy has a known and relatively low risk of severe adverse events. We found no long-term consequences from adverse events and no fatalities. 


\section{B A C K G R O U N D}

Allergic rhinitis is a significant public health concern in many countries and particularly so in the economically-developed world affecting up to $30 \%$ of adults (Gupta 2004; Bauchau 2004) and up to $40 \%$ of children (ISAAC 1998). The prevalence of allergic rhinitis has increased considerably in the last two decades, particularly in countries with a Western lifestyle (Fleming 1987; Ninan 1992; Mygind 1996; Jarvis 1998; Wilson 2003; Skoner 2001).

Allergic rhinitis has traditionally been categorised as being either 'seasonal', in which case pollen or moulds are the usual trigger, or 'perennial', in which case house dust mites or pet dander allergens are typically responsible, although in the tropics perennial symptoms can be caused by pollen and mould. However, allergic rhinitis is becoming increasingly assessed according to the frequency of symptoms (i.e. intermittent or persistent) and their severity and impact on patients' quality of life (i.e. mild or moderate/severe) (Bousquet 2001).

Allergic rhinitis is "a symptomatic disorder of the nose induced by an IgE-mediated inflammation after allergen exposure of the membranes lining the nose" (Bousquet 2001). The allergen provokes production of IgE antibodies which bind to mast cells releasing histamine and other inflammatory mediators. This pathway is responsible for immediate symptoms which can begin within a few minutes of exposure to the allergen. IgE production is triggered by T-lymphocytes which also control production of eosinophils and other inflammatory mediators responsible for the delayed reactions occurring a few hours after exposure (Lund 1994). Whilst the mechanism of immunotherapy is not completely understood, the most plausible explanation is that immunotherapy modifies the immune response by producing less of the 'harmful' antibodies (specific immunoglobulin (Ig) E) and more of the 'protective' antibodies called IgG (Frew 1993). Immunotherapy acts on specific cells called $T$ cells, to modify their peripheral and mucosal responses to allergen (Till 2004). This mechanism involves the switching from Th2 response (allergic response) in favour of Th1 response (non-allergic response) (Till 2004).

Clinical symptoms of allergic rhinitis include nasal itching, sneezing, watery nasal discharge, blocked nose and eye symptoms (Durham 1998). Treatment options include allergen avoidance, pharmacotherapy and immunotherapy. Recommended drug treatments include antihistamines, topical nasal steroids, antileukotriene receptor antagonists, mast cell stabilisers and, in some cases, a short course of systemic steroids or decongestants. For patients whose symptoms remain uncontrolled despite these treatments, allergen injection immunotherapy is advised (Lund 1994; Malling 2001).

Allergen immunotherapy by injection (also known as desensitisation or hyposensitisation) consists of an induction course of injections of increasing doses of the allergen extract, usually given weekly or fortnightly. The maintenance phase of maximum dosage injections usually lasts between two to three years (Frew 1993). Immunotherapy can also be delivered through the nasal, oral or sublingual (under the tongue) route; its efficacy by the sublingual method of delivery is the subject of a separate recently completed review (Wilson 2003; Wilson 2005). The effectiveness of immunotherapy by the oral and nasal route will also be studied in separate Cochrane reviews. Although injections can consist of mixed allergen extracts, there is some evidence that this can lead to degradation of the allergenic compounds, reducing the effect of the treatment (Dreborg 1992).

Specific allergen immunotherapy (SIT) for hay fever is widely considered to be effective where grass pollen (Varney 1991; Malling 2001), ragweed, and birch pollen (Viander 1978) are causal agents, and there is evidence that its efficacy may continue for many years beyond the treatment period (Mosbech 1988; Durham 1999b). However, there are concerns over its safety. In 1986 a report by the UK Committee on the Safety of Medicines (CSM 1986) suggested that deaths and adverse reactions from allergen immunotherapy were increasing. The UK Committee on the Safety of Medicines stipulated that this treatment be given only where full resuscitation facilities were available and that patients be observed for at least two hours after its administration. Although observation time was later reduced to one hour (CSM 1994), these restrictions effectively prevented administration of allergen immunotherapy in primary care in the UK, with the effect that availability was severely curtailed.

Not all sufferers are suitable candidates for this therapy. Some $13 \%$ to $38 \%$ of people with seasonal allergic rhinitis also suffer from asthma (Aberg 1989) and asthma sufferers have been identified as a group with a particularly high risk of adverse reactions and death from immunotherapy. For these reasons, many countries do not recommend immunotherapy in people with asthma, which excludes a large proportion of the population which might otherwise benefit. Despite the reduced availability of immunotherapy in the UK and Scandinavian countries, immunotherapy is still freely practiced in parts of Europe and in North America (Norman 1990; CSACl 1995).

There are many issues in immunotherapy which merit further investigation such as the possible long-term benefits of immunotherapy for seasonal allergic rhinitis or the suitability of this treatment for patients who also suffer from asthma. In this review, however, we focus on two key and fundamental questions: we intend to examine the efficacy and efficacy-risk profile of pollen immunotherapy for seasonal allergic rhinitis.

\section{O B JECT IVES}

To evaluate the efficacy and safety of subcutaneous allergen specific immunotherapy compared with placebo in seasonal allergic rhinitis.

\section{METHODS}

\section{Criteria for considering studies for this review}

\section{Types of studies}

Randomised, double-blind, placebo controlled trials.

\section{Types of participants}

Patients with seasonal allergic rhinitis due to tree, grass or weed pollens. We stipulated that allergy must be proven using an objective test such as positive skin prick tests or high circulating levels of allergen-specific IgE antibody detected by a specific blood test for allergy called radioallergoabsorbent test (RAST). Trials dealing with perennial allergic rhinitis and asthma alone were excluded. 


\section{Types of interventions}

Multiple injections of high dose immunotherapy with standardised single allergen extracts compared with placebo. All appropriate allergens were considered at all doses and all durations of treatment.

\section{Types of outcome measures}

\section{Primary outcome measures}

\section{Symptomatic}

Symptom scores: typically collected using symptom diaries (any permitted);

Patient-completed visual analogue rhinitis symptoms scores.

Clinical

\section{Medication use;}

Rhinoconjunctivitis quality of life questionnaire;

Compliance, i.e. whether patient completed treatment;

Doctor-completed visual analogue rhinitis symptom scores;

Adverse reactions: local (for example, swelling, itchiness) and systemic (for example, anaphylaxis);

Time to onset (in minutes) of systemic reactions.

\section{Secondary outcome measures}

Experimental outcomes as recorded in trials, such as skin reactivity (immediate phase (15 minutes) and late phase (6 to 24 hours)) and levels of specific IgE and IgG antibodies. These were deemed to be of secondary importance because their clinical usefulness is yet to be adequately established.

\section{Search methods for identification of studies}

Published, unpublished and ongoing studies were identified from the Cochrane Ear, Nose and Throat Disorders Group Trials Register, the Cochrane Central Register of Controlled Trials (CENTRAL, The Cochrane Library, Issue 1 2006), MEDLINE (1950 to 2006), EMBASE (1974 to 2006), KOREAMED, INDMED, LILACS, PAKMEDINET, Scisearch, $m R C T$ and the National Research Register. The date of the last search was February 2006.

The following search strategy was used to search CENTRAL:

\#1 RHINITIS ALLERGIC SEASONAL single term (MeSH)

\#2 hayfever OR hay NEXT fever OR pollinosis OR pollenosis OR SAR OR pollen NEAR allerg*

\#3 \#1 OR \#2

\#4 RHINITIS single term(MeSH)

\#5 rhiniti*

\#6 \#4 OR \#5

\#7 season ${ }^{\star}$ OR spring OR summer OR pollen OR grass ${ }^{\star}$ OR birch OR ragweed OR tree* OR weed* OR mugwort OR willow OR alder \#8 \#6 AND \#7

\#9 \#3 OR \#8

\#10 DESENSITIZATION IMMUNOLOGIC single term (MeSH)

\#11 ALLERGENS [im] single term (MeSH)

\#12 ALLERGENS [tu] single term (MeSH)

\#13 ALLERGENS [ad] single term (MeSH)

\#14 IMMUNOTHERAPY single term (MeSH)

\#15 POLLEN [im] single term (MeSH)

\#16 POACEAE [im] single term (MeSH)
\#17 DOSE RESPONSE RELATIONSHIP, IMMUNOLOGIC single term (MeSH)

\#18 immunotherapy OR immunomodulatory OR immune NEAR therapy OR immunologic NEAR response* OR allergen ${ }^{\star}$ OR antigen ${ }^{\star}$ OR desensiti* OR hyposensiti*

\#19 \#10 OR \#11 OR\#12 OR\#13 OR\#14 OR\#15 OR\#16 OR\#17 OR\#18 \#20 \#9 AND \#19

All other search strategies were modelled on the CENTRAL version. The terms were combined with the highly sensitive search strategy for identifying clinical trials, described in Appendix $5 \mathrm{c}$ of the Cochrane Reviewers' Handbook, to search MEDLINE.

We considered studies published in languages other than English if the translated abstract indicated that the study was a randomised controlled trial of subcutaneous allergen specific immunotherapy for seasonal allergic rhinitis and we used translators provided by the Cochrane ENT Group.

The bibliography of each paper and of other published reviews was checked for further references. The primary author of each study was contacted to identify additional published and unpublished studies.

Abstracts of relevant conferences were searched and other trials were identified through discussion with specialist allergist colleagues and professional acquaintances with an interest in the area to enquire whether they were aware of any unpublished or ongoing trials meeting the selection criteria. Reference lists of recent reviews and published trials were searched.

\section{Data collection and analysis}

\section{Study selection}

Three independent authors (MC, BA, MJ) checked titles and abstracts identified from the searches. Both authors obtained the full text of all studies of possible relevance for assessment. The authors (MC, BA, MJ) read all abstracts and decided which trials met the inclusion criteria and graded their methodological quality. Any disagreement was resolved by discussion between the authors with recourse to a third reviewer (AS or SD) for arbitration where necessary. Authors were contacted for clarification where necessary. Further information was sought from study authors when needed. The selected studies were then further evaluated for methodological quality to select those suitable for meta-analysis.

\section{Data extraction}

Each of the suitable reports were read in detail by MC, BA and $\mathrm{MJ}$ and relevant details were abstracted on to a standard extraction sheet (covering study type and methodology; number and description of subjects; details of type, dosage and time schedule/ duration of intervention; type, timing and measurement method of outcomes). Concealment of allocation and blinding of study participants and investigators was assessed according to the guidelines of the Cochrane Collaboration.

\section{Quality assessment}

Methodological quality was assessed using the following approach: 


\section{Concealment of allocation to the intervention or placebo arm of} trial

A - Adequate; for example, centralised randomisation by a central office.

B - Unclear; list or table or apparently adequate concealment but no other information in trial.

C - Unmet; alternation, days of the week, any allocation that is potentially transparent.

\section{Attrition bias}

A - Adequate; trials where an intention to treat analysis is possible and drop out rate was less than $20 \%$ after one year in all groups.

B - Unclear; trials where drop out rate was more than $20 \%$ after one year or large differences in drop out rates between groups were observed.

C - Unmet; No reporting on drop out rates and intention to treat analysis not possible.

\section{Detection bias}

A - Adequate; trials in which blinding of investigators assessing outcomes was adequate.

B - Unclear; trials in which blinding of investigators was not described adequately.

C - Unmet; trials in which blinding of investigators was clearly not performed.

Trials which fell into allocation concealment category $\mathrm{C}$ were excluded from the analysis and the remaining studies were given an overall score using the following criteria:

A - Low risk of bias, where all criteria were 'Adequate'.

B - Medium risk of bias, where one or more criteria were 'Unclear' and the rest were 'Adequate'.

C - High risk of bias, where one or more criteria were unmet.

Study quality was used in a sensitivity analysis. Due to prior familiarity with the content of most studies, authors names were not removed before assessment.

\section{Data analysis}

Outcome data, extracted from the included studies, were entered into RevMan 4.2.8 for statistical analysis. All outcome data on efficacy that were analysed were continuous (symptom scores, medication scores) but authors used a wide variety of scoring systems and scales for symptoms (most frequently a daily quantification of nasal, ocular and chest symptoms entered on a diary card and subsequently totalled and averaged) and rescue medication use (typically a daily score reflecting use of oral antihistamines tablets, eye drops and nasal sprays entered on a diary card and subsequently totalled and averaged).

Adverse reactions (dichotomous outcome) were recorded by people or by injection, as local or systemic reactions. Systemic reactions were graded according to time of onset (early within 30 minutes and late after 30 minutes) and severity of reaction. For assessing the severity of systemic reactions we followed the grading system proposed in the Position Paper of the European Academy of Allergology and Clinical Immunology on Immunotherapy (Malling 1993):

Grade 1: Non-specific reactions: Reactions probably not IgEmediated; i.e. discomfort, headache, arthralgia, etc.
Grade 2: Mild systemic reactions: Mild rhinitis and/or asthma (peak expiratory flow rates (PEFR) over $60 \%$ of predicted or of the personal best values) responding adequately to antihistamines or inhaled B2-agonists.

Grade 3: Non life-threatening systemic reactions: Urticaria, angioedema, or severe asthma (PEFR under $60 \%$ of predicted or of personal best values) responding well to treatment.

Grade 4: Anaphylactic shock: Rapidly evoked reaction of itching, flushing, erythema, bronchial obstruction, etc. requiring intensive treatment.

Two key analyses were carried out:

An examination of the efficacy of immunotherapy during the period of the treatment;

An examination of the risks of serious adverse reactions due to treatment.

Quantitative analyses of outcomes were presented on an intentionto-treat basis. Meta-analysis was performed, where appropriate, using a random-effects model to obtain summary statistics for the overall efficacy of subcutaneous immunotherapy. We planned to express categorical data as odds ratios or relative risks (with 95\% confidence intervals). For continuous data, the Standardised Mean Difference (SMD) was calculated (with 95\% Confidence Intervals). SMD standardises the outcome for each individual study to the effect size found in terms of the standard deviation observed (in the study). The use of SMD is generally the method used for pooling data from different scales. Chi-squared tests were performed to assess heterogeneity between studies, with a $\mathrm{P}$ value $<0.05$ indicating significant differences between studies.

The following subgroups of comparisons between active and placebo treated subjects were proposed prior to undertaking the data analysis:

\section{1 - SYMPTOM SCORES}

2 - MEDICATION SCORES

3 - SYMPTOM AND MEDICATION SCORES

4 - NASAL SYMPTOM SCORES

5 - BRONCHIAL SYMPTOM SCORES

6 - OCULAR SYMPTOM SCORES

7 - GLOBAL IMPROVEMENT

8 - RHINOCONJUNCTIVITIS QUALITY OF LIFE

9 - ADVERSE EVENTS

9.1 - LOCAL REACTION

9.1.1 - Local reaction not requiring treatment

9.1.2 - Local reaction requiring treatment

$9 . .2$ - SYSTEMIC REACTION

9.2.1 - Early systemic reaction grade 2 (<30 minutes)

9.2.2 - Early systemic reaction grade 3 ( $<30$ minutes)

9.2.3 - Early systemic reaction grade 4 ( $<30$ minutes)

9.2.4 - Late systemic reaction ( $>30$ minutes)

9.2.5 - Systemic reaction - severity and time of onset not specified

10 - ADRENALINE USE

11 - COST

12 - SERUM ANTIBODY LEVELS

12.1 - Specific IgG

12.2 - Specific IgG-4

12.3 - Specific IgE

13 - SPECIFIC ALLERGEN CHALLENGES

13.1 - Nasal Challenge

13.2 - Conjunctival Challenge

13.3 - Skin Challenge 
13.4 - Bronchial Challenge 14 - DEATHS

Where appropriate, additional analyses were performed according to subgroup.

Characteristics of the treatments and participants with highest and lowest relative risk of adverse reaction were described.

Tests for heterogeneity were performed and if found to be significant, possible explanations were sought through examination of study quality and type of immunotherapy.

We used a funnel plot to investigate the possibility of publication bias.

\section{RE S U L T S}

\section{Description of studies}

Our searches identified 1111 abstracts of potential relevance, of which 276 were selected for in-depth appraisal of full text papers. Fifty-one full papers satisfied our inclusion criteria. The methods, participants, interventions and outcomes of the included studies are listed in the table of Characteristics of Included Studies. In total there were 2871 participants: 1645 active and 1226 placebo, each receiving on average 18 injections. All studies included patients with seasonal allergic rhinitis. Symptom score data from 15 trials were suitable for meta-analysis.

Six studies specified that patients did not experience co-existent asthma; in 27 studies patients had mild to moderate seasonal allergic asthma; 18 studies did not specify the asthmatic status of their participants.

A wide range of allergens were administered in these studies: ragweed (12), mixed grass (16), timothy (5), parietaria (6), birch (4), $\operatorname{orchard}(2), \operatorname{cedar}(3)$, bermuda (1), juniperus ashei (1) and cocos (1).

The types of vaccines used were extracts (38), allergoids (12) and non-specified (1).

The duration of maintenance treatment and the period of follow up varied considerably between studies, largely reflecting preseasonal, co-seasonal and post-seasonal administration. Duration of immunotherapy varied from three days (minimum duration) to three years (maximum duration). Six studies did not mention the duration of treatment.

It was not possible from most of the studies to determine accurately the dose of allergen given in terms of micrograms of major allergen. Doses given were quantified in many different units including $\mathrm{BU}$, PNU, BU, SQ-U, mcg Ag, SE-U, Aueq, SU/ml, TU, wt/vol and HEP.

The reasons for excluding the 230 studies were:

Not a double-blind randomised placebo controlled study (23);

Not a double-blind placebo controlled study (16);

Not a double-blind study (7);

Not a placebo controlled study (58);

Not a randomised study (6);

Route other than subcutaneous (12);

Single or low dose immunotherapy (5);

Not a specific immunotherapy study (25);

No standardised allergen extracts used (4);
Rinkel method (very low-dose co-seasonal immunotherapy) (2); No allergen extract used (4);

Other outcomes investigated (28);

Comparison of two different immunotherapy preparations (3);

Not a seasonal allergic rhinitis study (11);

Patients were asthmatics, not rhinitics (6);

Peptide immunotherapy used (1);

Review article (4);

Follow-up study (1);

Some patients had previous immunotherapy (4);

Survey study (1);

Withdrawal of treatment study (3);

Data included in another paper (5);

Insufficient data for analysis (1).

\section{Risk of bias in included studies}

All included studies were double-blind placebo controlled trials of parallel group design. Concealment of treatment, based on statements made by the original authors, was considered adequate in all studies. Blinding of study subjects and investigators was almost universally maintained by use of similar placebo preparations. Overall score for methodological quality was found to be 'low risk of bias' in 42 studies, 'medium risk of bias' in five studies, 'high risk of bias' in one study, and undetermined in three studies. Full details, including quality scores, are set out in the table of 'Characteristics of Included Studies'.

\section{Effects of interventions}

The decision to pool studies in the following meta-analyses, despite evidence of heterogeneity, was taken as it was clear for all outcomes that all of the pooled studies showed a consistent direction of effect. We believe the pooled results give an idea of the direction and size of the effect of subcutaneous immunotherapy.

\section{Symptom scores}

Most of the included studies reported symptom scores, recorded in patient diaries, as a primary outcome measure. Data obtained in this way are almost always non-normally distributed (skewed) and therefore many studies reported results as median values. Strenuous attempts were made to obtain means and standard deviations direct from authors and values were only included after data were obtained. Only 15 studies met all criteria for symptom score meta-analysis; these included active immunotherapy subjects $n=597$ and placebo subjects $n=466$ (Balda 1998; Bodtger 2002; Bousquet 1990; Brewczynski 1999; Corrigan 2005; Drachenberg 2001; Ferrer 2005; Frew 2006; Jutel 2005; Meriney 1986; Ortolani 1984; Ortolani 1994; Varney 1991; Walker 2001 (Delta values were used for this study); Zenner 1997).

The combined Standardised Mean Difference (SMD) for symptom scores following subcutaneous immunotherapy was $-0.73(95 \% \mathrm{Cl}$ -0.97 to $-0.50, \mathrm{P}<0.00001$ ), indicating a significant reduction in symptom scores. There was evidence of significant heterogeneity between studies $(P<0.0005)$, but no unifying reasons were found to explain the difference of effect in the studies included. See Analysis 1.1.

Frew 2006 is the largest trial assessing the efficacy and safety of SIT for grass pollen allergy conducted to date. The trial was a three arm study: the first active group $(n=203)$ received standardised depot preparations of grass pollen extract (Alutard SQ-U, Phleum 
pratense) at the dosage $100,000 \mathrm{SQ}-\mathrm{U}$, the second active group $(\mathrm{n}=104)$ received the same at the dosage $10,000 \mathrm{SQ}-\mathrm{U}$, and the third group $(n=103)$ a placebo. Sensitivity analysis was performed by replacing the $100,000 \mathrm{SQ}-U$ data included in the above metaanalysis with the data from the $10,000 \mathrm{SQ}-\mathrm{U}$ arm, to test the effect on the result. The revised combined SMD was $-0.73(95 \% \mathrm{Cl}-0.97$ to -0.49) $(P<0.00001)$. Significant heterogeneity between studies was still evident $(P<0.0004)$.

Of the 16 further studies that it was not possible to include in the above meta-analysis all 16 favoured the intervention group. A description of data from these studies can be found in Table 1 .

\section{Medication scores}

Diary scores reflecting concurrent use of anti-allergic medication were reported in 13 studies; these included active immunotherapy participants $n=549$ and placebo participants $n=414$ (Balda 1998; Bodtger 2002; Bousquet 1990; Brewczynski 1999; Corrigan 2005; Dolz 1996; Drachenberg 2001; Ferrer 2005; Frew 2006; Jutel 2005; Mirone 2004; Varney 1991; Walker 2001 (Delta values were used for this study)). In the study Dolz 1996 the decrease in medical treatment was statistically significant in the springs of 1991 and $1992(\mathrm{P}<0.01)$, but not in spring 1990 .

The combined SMD for medication scores following immunotherapy was $-0.57(95 \% \mathrm{Cl}-0.82$ to $-0.33, \mathrm{P}<0.00001)$ indicating a significant reduction in medication scores. There was evidence of significant heterogeneity between studies $(P<0.0009)$, but no unifying reasons were found to explain the difference of effect in the studies included. See Analysis 1.2.

Sensitivity analysis was again performed for the Frew 2006 study by replacing the $100,000 \mathrm{SQ}-\mathrm{U}$ data included in the above metaanalysis with the data from the 10,000 SQ-U arm, to test the effect on the result. The revised combined SMD was $-0.56(95 \% \mathrm{Cl}-0.82$ to $-0.30, \mathrm{P}<0.0001)$. Significant heterogeneity between studies was still evident $(P<0.0004)$.

Of the 12 studies that were not included in the meta-analysis, 11 favoured the intervention group. A description of data from these studies can be found in Table 2 .

\section{Symptom and medication scores}

Eight studies were included for symptom and medication score analysis, which comprised active immunotherapy subjects $n$ $=320$ and placebo subjects $\mathrm{n}=297$ (Balda 1998; Corrigan 2005; Drachenberg 2001; Ferrer 2005; Jutel 2005; Ortolani 1994; Pastorello 1992; Zenner 1997).

The combined SMD for medication and symptom scores following subcutaneous immunotherapy was $-0.48(95 \% \mathrm{Cl}-0.67$ to -0.29 , $\mathrm{P}<0.00001$ ) indicating a significant reduction in symptom and medication scores in the immunotherapy treated group. There was no evidence of heterogeneity between studies $(P=0.25)$. See Analysis 1.3.

Of the 16 studies that were not included in the meta-analysis all 16 studies favoured the intervention group. A description of data from these studies can be found in Table 3 .

\section{Nasal symptom scores}

Nine studies were included for nasal symptom score analysis, which comprised active immunotherapy subjects $\mathrm{n}=396$ and placebo subjects $\mathrm{n}=276$ (Balda 1998; Bousquet 1987b; D'Amato 1995; Dolz 1996; Ferrer 2005; Frew 2006; Mirone 2004; Zenner 1997). In D'Amato 1995 mean (SD) values for nasal block obtained from visual analogue scores for patients completing two years of treatment (active or placebo) were chosen as representative parameters for meta-analysis. In Dolz 1996 the nasal symptoms improved significantly during the springs of 1991 and 1992, but this result did not occur during spring 1990. In Zenner 1997 median nasal symptom scores and overall symptom scores were significantly lower in the specific immunotherapy group compared to the placebo group $(P=0.014$ for nasal symptoms and $P=0.02$ for overall symptoms).

The combined SMD for nasal symptom scores following subcutaneous immunotherapy was $-1.59(95 \% \mathrm{Cl}-2.29$ to -0.89 , $\mathrm{P}<0.00001$ ) indicating a significant reduction in nasal symptom scores in the immunotherapy treated group. There was evidence of heterogeneity between studies $(P<0.00001)$, but no reason was found to explain the difference of effect in the studies included. See Analysis 1.4.

Sensitivity analysis was performed for the Frew 2006 study by replacing the $100,000 \mathrm{SQ}-U$ data included in the above metaanalysis with the data from the 10,000 SQ-U arm, to test the effect on the result. The revised combined SMD was $-1.59(95 \% \mathrm{Cl}-2.33$ to $-0.86, \mathrm{P}<0.0001)$. Significant heterogeneity between studies was still evident $(P<0.00001)$.

Of the eight studies not included in the meta-analysis, seven favoured the intervention group. A description of data from these studies can be found in Table 4 .

\section{Bronchial symptom scores}

Five studies were included for bronchial symptom score analysis, comprising active immunotherapy subjects $n=266$ and placebo subjects $n=163$ (Balda 1998; Dolz 1996; Ferrer 2005; Frew 2006; Mirone 2004). In Dolz 1996 the bronchial symptoms showed a statistically significant improvement $(P<0.001)$ during the springs of 1990 and 1991. In spring 1992, the bronchial symptoms in the active group did not appear. In the placebo group, they were mild in the first days. All patients took bronchodilator and/or inhaled corticoids every day during the spring and summer. Therefore, the bronchial symptom scores in this group were not easily registered.

The combined SMD for bronchial symptom scores following subcutaneous immunotherapy was $-0.59(95 \% \mathrm{Cl}-1.06$ to -0.11 , $\mathrm{P}=0.02$ ) indicating a significant reduction in bronchial symptom scores in the immunotherapy treated group. There was evidence of heterogeneity between studies $(P=0.007)$, but no reason was found to explain the difference of effect in the studies included. See Analysis 1.5.

Sensitivity analysis was again performed for the Frew 2006 study by replacing the $100,000 \mathrm{SQ}-U$ data included in the above metaanalysis with the data from the $10,000 \mathrm{SQ}-\mathrm{U}$ arm, to test the effect on the result. The revised combined SMD was $-0.60(95 \% \mathrm{Cl}-1.02$ to $-0.19, \mathrm{P}<0.004)$. Significant heterogeneity between studies was still evident $(P<0.04)$. 
Of the ten studies not included in the meta-anlysis, eight favoured the intervention group. A description of data from these studies can be found in Table 5 .

\section{Ocular symptom scores}

Three studies were included for ocular symptom score analysis, comprising active immunotherapy subjects $\mathrm{n}=226$ and placebo subjects $\mathrm{n}=119$ (Dolz 1996; Ferrer 2005; Frew 2006). The combined SMD for ocular symptom scores following subcutaneous immunotherapy was $-1.80(95 \% \mathrm{Cl}-3.28$ to -0.31$)(\mathrm{P}<0.02)$ indicating a significant reduction in ocular symptom scores in the immunotherapy treated group. There was evidence of heterogeneity between studies $(P<0.00001)$, but no reason was found to explain the difference of effect in the studies included. See Analysis 1.6.

Data obtained for this outcome were almost always non-normally distributed (skewed) and therefore many studies reported results as median values. Strenuous attempts were made to obtain mean (standard deviation) data direct from authors and values were only included after data were obtained. Leynadier 2001 provided mean values but not SD values as requested.

Sensitivity analysis was performed for the Frew 2006 study by replacing the $100,000 \mathrm{SQ}-\mathrm{U}$ data included in the above metaanalysis with the data from the $10,000 \mathrm{SQ}-\mathrm{U}$ arm, to test the effect on the result. The revised combined SMD was $-1.80(95 \% \mathrm{Cl}-3.33$ to $-0.27)(P<0.02)$. Significant heterogeneity between studies was still evident $(P<0.00001)$.

Of the nine studies not included in the meta-analysis, six favoured the intervention group. A description of data from these studies can be found in Table 6 .

\section{Global improvement}

Data obtained for this outcome were almost always non-normally distributed (skewed) and therefore many studies reported results as median values. Of the nine studies all favoured the intervention group. A description of data from these studies can be found in Table 7.

\section{Rhinoconjunctivitis quality of life}

Five studies were included in the rhinoconjunctivitis quality of life meta-analysis, comprising active immunotherapy subjects $n=332$ and placebo subjects $n=239$ (Corrigan 2005; Ferrer 2005; Frew 2006; Jutel 2005; Walker 2001). The combined SMD for rhinoconjunctivitis quality of life following subcutaneous immunotherapy was -0.52 $(95 \% \mathrm{Cl}-0.69$ to $-0.34, \mathrm{P}<0.00001)$ indicating a clinically and statistically significant improvement in rhinoconjunctivitis quality of life in the immunotherapy treated group. There was no evidence of heterogeneity between studies $(P=0.50)$. See Analysis 1.9.

Sensitivity analysis was performed for the Frew 2006 study by replacing the $100,000 \mathrm{SQ}-U$ data included in the above metaanalysis with the data from the 10,000 SQ-U arm, to test the effect on the result. The revised combined SMD was $-0.39(95 \% \mathrm{Cl}-0.57$ to $0.21, P<0.0001$ ). Again there was no evidence of heterogeneity between studies $(P=0.74)$.

In the Alvarez-Cuesta 2005 study, during the pollen season, immunotherapy treated patients had significantly greater improvements both in overall (Rhinitis Quality of Life Questionnaire
(RQLQ)) and in five of the seven Health-Related Quality of Life (HRQL) domains (sleep, non-hayfever symptoms, practical problems, nasal symptoms and eye symptoms). These differences also reached, or surpassed, the proposed threshold of clinical relevance $(>0.5 \mathrm{U})$ for total score and the five domains, including practical problems. Overall quality of life mean $(95 \% \mathrm{Cl})$ was 1.74 (1.50 to 1.98 ) for the immunotherapy group and 2.34 (1.87 to 2.81 ) for the placebo group $(P<0.05)$. Although mean values were given, no SD was provided therefore it was not possible to include this study in the meta-analysis.

\section{Adverse events}

Adverse events were searched for in all studies included in this review. Comparisons were made between subjects treated with subcutaneous allergen specific immunotherapy and subjects treated with placebo control. Adverse events were analysed as local or systemic reactions. Local reactions were analysed in two subgroups according to their need for treatment. Systemic reactions were analysed according to their severity (grading system) and time of onset (before or after 30 minutes) as described above.

The following paragraphs and data provide an overview of the adverse events reported in the included studies. Combining these can be problematic. Ideally a formal meta-analysis would be undertaken. However, most studies reported number of adverse events, rather than the number of participants in which one or more adverse events were observed, making such an analysis difficult. Although it might appear both clinically appropriate and mathematically simple to add up the number of events and divide this by the number of injections or participants (and we do indeed present some of these data) there is a danger that such pooling may undermine the effects of the randomisation process in the individual trials. As a result these data should be considered with some caution.

\subsection{Local reaction}

Thirty studies reported local reactions in their outcomes, which comprised $n=999$ active immunotherapy subjects and $n=697$ placebo subjects (Alvarez-Cuesta 2005; Arvidsson 2002; ArmentiaMedina 1989; Balda 1998; Bodtger 2002; Bousquet 1990; Brunet 1992a; Corrigan 2005; D'Amato 1995; Dolz 1996; Drachenberg 2001; Durham 1999; Ferrer 2005; Frew 2006; Grammer 1982; Grammer 1983; Grammer 1984a; Grammer 1986; Grammer 1987; Jutel 2005; Karmaker 1994; Lee 1982; Leynadier 2001; Meriney 1986; Ortolani 1984; Ortolani 1994; Pastorello 1992; Tari 1997; Walker 2001; Zenner 1997).

\subsubsection{Local reaction not requiring treatment}

Twenty-four studies reported local reactions not requiring treatment; 834 events were reported in the immunotherapy treated group $(92 \%$, number of participants $=907)$ and 227 events in the placebo group $(33 \%$, number of participants $=697$ ) (Alvarez-Cuesta 2005; Armentia-Medina 1989; Balda 1998; Bodtger 2002; Bousquet 1990; Brunet 1992a; Corrigan 2005; D'Amato 1995; Drachenberg 2001; Ferrer 2005; Frew 2006; Grammer 1982; Grammer 1983; Grammer 1984a; Grammer 1986; Grammer 1987; Jutel 2005; Karmaker 1994; Lee 1982; Leynadier 2001; Meriney 1986; Ortolani 1984; Ortolani 1994; Zenner 1997). 


\subsubsection{Local reaction requiring treatment}

Seven studies reported local reactions requiring treatment; 21 events were reported in the immunotherapy treated group $(10 \%$, number of participants $=208$ ) and eight events in the placebo group $(4 \%$, number of participants $=186)$ (Balda 1998; Bodtger 2002; D'Amato 1995; Dolz 1996; Grammer 1983; Lee 1982; Zenner 1997).

\subsection{Systemic reaction}

Thirty-three studies reported systemic reactions in their outcomes; $\mathrm{n}=1051$ active immunotherapy subjects and $\mathrm{n}=857$ placebo subjects (Alvarez-Cuesta 2005; Armentia-Medina 1989; Arvidsson 2002; Balda 1998; Bodtger 2002; Bousquet 1987a; Bousquet 1987b; Bousquet 1990; Corrigan 2005; D'Amato 1995; Dolz 1996; Drachenberg 2001; Durham 1999; Ferrer 2005; Fling 1989; Frew 2006; Grammer 1982; Grammer 1983; Grammer 1984a; Grammer 1986; Grammer 1987; Iliopoulos 1991; Jutel 2005; Leynadier 2001; Meriney 1986; Metzger 1981; Mirone 2004; Ortolani 1984; Ortolani 1994; Pastorello 1992; Tari 1997; Walker 2001; Zenner 1997).

\subsubsection{Early systemic reaction grade $\mathbf{2}$ ( $<30$ minutes)}

Seventeen studies reported early systemic reactions grade 2 (<30 minutes) in their outcomes (Alvarez-Cuesta 2005; ArmentiaMedina 1989; Arvidsson 2002; Balda 1998; Bodtger 2002; Corrigan 2005; Dolz 1996; Drachenberg 2001; Ferrer 2005; Frew 2006; Iliopoulos 1991; Jutel 2005; Leynadier 2001; Mirone 2004; Ortolani 1994; Tari 1997; Zenner 1997); 154 events were reported in the immunotherapy treated group $(22 \%$, number of participants $=706)$ and 44 events in the placebo group $(8 \%$, number of participants $=$ 566).

\subsubsection{Early systemic reaction grade 3 ( $<30$ minutes)}

Thirteen studies reported early systemic reactions grade 3 (<30 minutes) in their outcomes (Alvarez-Cuesta 2005; Armentia-Medina 1989; Balda 1998; Bousquet 1987a; Bousquet 1987b; Corrigan 2005; Ferrer 2005; Frew 2006; Jutel 2005; Leynadier 2001; Metzger 1981; Ortolani 1994; Zenner 1997); 43 events were reported in the immunotherapy treated group $(7 \%$, number of participants $=$ $615)$ and three events in the placebo group $(0.65 \%$, number of participants $=463$ ).

\subsubsection{Early systemic reaction grade 4 ( $<30$ minutes)}

Nine studies reported early systemic reactions grade $4 \quad(<30$ minutes) in their outcomes (Alvarez-Cuesta 2005; Armentia-Medina 1989; Corrigan 2005; Ferrer 2005; Fling 1989; Frew 2006; Jutel 2005; Mirone 2004; Ortolani 1994); three events were reported in the immunotherapy treated group $(0.72 \%$, number of participants $=417)$ and one event in the placebo group $(0.33 \%$, number of participants $=303$ )

\subsubsection{Late systemic reaction (> 30 minutes)}

Eleven studies reported late systemic reactions ( $>30$ minutes) in their outcomes (Balda 1998; Bodtger 2002; Bousquet 1990; Corrigan 2005; Ferrer 2005; Frew 2006; Jutel 2005; Ortolani 1994; Pastorello 1992; Walker 2001; Zenner 1997); 458 events were reported in the immunotherapy treated group ( $89 \%$, number of participants $=514$ ) and 148 events in the placebo group (36\%, number of participants $=412$ ).

\subsection{5 - Systemic reaction - severity and time of onset not specified}

Three studies reported systemic reactions with the severity not specified in their outcomes (Bousquet 1991; Karmaker 1994; Lee 1982); 12 events were reported in the immunotherapy treated group $(8.5 \%$, number of participants $=142)$ and no events in the placebo group (number of participants $=63$ ).

\section{Adrenaline use}

Thirteen studies reported use of adrenaline (Alvarez-Cuesta 2005; Corrigan 2005; Dolz 1996; Bousquet 1987a; Bousquet 1987b; Ferrer 2005; Fling 1989; Frew 2006; Iliopoulos 1991; Jutel 2005; Metzger 1981; Mirone 2004; Ortolani 1994); 19 events were reported in the immunotherapy treated group $(0.13 \%$, number of injections given $=14,085)$ and 1 event in the placebo group $(0.01 \%$, number of injections given $=8278$ ) (see Figure 1$)$.

Figure 1.

\begin{tabular}{|c|c|c|c|c|c|}
\hline \multicolumn{6}{|c|}{ Adrenaline use (in 13 studies) } \\
\hline \multicolumn{3}{|c|}{ A ctive } & \multicolumn{3}{|c|}{ Placebo } \\
\hline $\begin{array}{l}\text { Adrenaline } \\
\text { use }\end{array}$ & $\begin{array}{c}\text { Partic ipants } \\
(\%)\end{array}$ & $\begin{array}{c}\text { Injections } \\
(\%)\end{array}$ & $\begin{array}{c}\text { Adrenaline } \\
\text { use }\end{array}$ & $\begin{array}{c}\text { Participants } \\
(\%)\end{array}$ & $\begin{array}{c}\text { Injections } \\
(\%)\end{array}$ \\
\hline 19 & $\begin{array}{c}557 \\
(3.41)\end{array}$ & $\begin{array}{c}14,085 \\
(0.13)\end{array}$ & 1 & $\begin{array}{c}404 \\
(0.25)\end{array}$ & $\begin{array}{l}8,278 \\
(0.01)\end{array}$ \\
\hline
\end{tabular}




\section{Cost}

Not a single study included assessment of cost.

\section{Serum antibody levels}

\subsection{Specific IgG}

Twenty-eight studies measured changes in specific IgG (ArmentiaMedina 1989; Bousquet 1987a; Bousquet 1987b; Bousquet 1988; Bousquet 1989; Bousquet 1990; Bousquet 1991; Brewczynski 1999; Brunet 1992a; Dolz 1996; Drachenberg 2001; Fling 1989; Grammer 1982; Grammer 1983; Grammer 1986; Grammer 1987; Iliopoulos 1991; Juniper 1985; Karmaker 1994; Litwin 1991; Meriney 1986; Metzger 1981; Norman 1982; Ortolani 1984; Ortolani 1994; Pastorello 1992; Tari 1997). All studies reported a significant increase in specific IgG levels after treatment with specific immunotherapy compared with placebo.

Of these, only four studies provided suitable data for meta-analysis (Drachenberg 2001; Ortolani 1984; Ortolani 1994; Pastorello 1992); which comprised active immunotherapy subjects $n=107$ and placebo subjects $n=84$. The combined SMD was 1.90 (95\% Cl 0.88 to $2.93(P=0.0003))$ indicating a significant increase of specific IgG in the immunotherapy treated group. There was evidence of heterogeneity between studies $(P=0.001)$, but no reason was found to explain the difference of effect in the studies included. See Analysis 1.7.

Description of data from studies not included in the meta-analysis is presented in Table 8.

\subsection{Specific IgG4}

Eleven studies measured changes in specific IgG4 (Ariano 1999; Balda 1998; Brewczynski 1999; Dolz 1996; Fling 1989; Leynadier 2001; Ortolani 1984; Ortolani 1994; Pastorello 1992; Tari 1997; Zenner 1997). All studies, except one (Fling 1989) reported a significant increase in specific IgG4 levels after treatment with specific immunotherapy compared with placebo.

Of these, only five studies provided suitable data for meta-analysis (Balda 1998; Corrigan 2005; Dolz 1996; Jutel 2005; Zenner 1997), comprising active immunotherapy subjects $\mathrm{n}=206$ and placebo subjects $\mathrm{n}=198$. The combined SMD was $0.79(95 \% \mathrm{Cl} 0.49$ to $1.08(P<0.00001))$ indicating a significant increase of specific IgG4 in the immunotherapy treated group. There was no evidence of heterogeneity between studies $(P=0.14)$. See Analysis 1.8.

Description of data from studies not included in the meta-analysis is presented in Table 9.

\subsection{Specific IgE}

Thirty studies measured changes in allergen specific IgE; of these, 20 studies reported an increase in specific IgE levels (Ariano 1999; Armentia-Medina 1989; Bousquet 1987a; Bousquet 1988; Bousquet 1989; Bousquet 1990; Brunet 1992a; Grammer 1986; Grammer 1987; Iliopoulos 1991; Juniper 1985; Karmaker 1994; Lee 1982; Leynadier 2001; Litwin 1991; Metzger 1981; Norman 1982; Pastorello 1992; Zenner 1997).

Nine studies reported no changes in these levels (Balda 1998; Bodtger 2002; Brewczynski 1999; Dolz 1996; Drachenberg 2001; Meriney 1986; Ortolani 1984; Ortolani 1994; Tari 1997). One study
(Fling 1989) reported a reduction of specific IgE levels measured during the pollen season after immunotherapy.

Data were not suitable for meta-analysis, therefore, description of data from studies is presented in Table 10.

\section{Specific allergen challenges}

\subsection{Nasal challenge}

Thirteen studies performed nasal challenges (Bodtger 2002; Bousquet 1987b; Bousquet 1988; Bousquet 1990; Bousquet 1991; Brunet 1992a; D'Amato 1995; Iliopoulos 1991; Leynadier 2001; Ortolani 1994; Pastorello 1992; Tari 1997). Most of the studies showed an increase in the allergen provocation dose for the active treatment group.

Data were not suitable for meta-analysis, therefore, description of data from studies is presented in Table 11.

\subsection{Conjunctival challenge}

Six studies performed conjunctival challenges; of these, four studies (Dolz 1996; Durham 1999; Ortolani 1994; Varney 1991) showed an increased in the conjunctival threshold dose of allergen after immunotherapy. Two studies showed no differences in both groups (Arvidsson 2002; Bodtger 2002).

Data were not suitable for meta-analysis, therefore description of data from studies is presented in Table 12.

\subsection{Skin challenge}

Twenty-one studies performed skin challenges (Ariano 1999; Armentia-Medina 1989; Bodtger 2002; Bousquet 1987a; Bousquet 1988; Bousquet 1989; Bousquet 1990; Bousquet 1991; D'Amato 1995 ; Dolz 1996; Drachenberg 2001; Durham 1999; Fling 1989; Iliopoulos 1991; Leynadier 2001; Ortolani 1994; Pastorello 1992; Tari 1997; Varney 1991; Walker 2001; Zenner 1997). All studies reported a reduction in the skin reactivity after immunotherapy.

Data were not suitable for meta-analysis, therefore description of data from studies is presented in Table 13.

\subsection{Bronchial challenge}

Three studies performed bronchial challenges (Armentia-Medina 1989; Dolz 1996; Ortolani 1984). Data were not suitable for metaanalysis, therefore description of data from studies is presented in Table 14.

\section{Deaths}

No fatal events were reported in any of the studies included in this systematic review.

\section{DISCUSSION}

We have performed a comprehensive systematic review of the effectiveness of subcutaneous injection specific allergen immunotherapy in patients with seasonal allergic rhinitis.

This systematic review found 51 randomised controlled trials which satisfied our inclusion criteria. Symptom scores were described as significantly reduced in 31 studies and medication scores were also described as significantly reduced in 24 studies. However, symptom score data from only 15 studies and medication score data from 
only 13 studies were suitable for meta-analyses. These studies were identified through an extensive search of the published and unpublished literature and this review therefore represents, we believe, a state of the art and up-to-date synthesis of the best evidence available (up to February 2006) on the efficacy and safety of injection specific allergen immunotherapy in patients with seasonal allergic rhinitis.

A degree of caution in interpretation of these data is required as there was significant heterogeneity between studies which maybe due to the wide variety of scoring systems used across studies. This is in part compensated for by use of the standardised mean difference in the analyses. Furthermore, it is difficult to know what constitutes a clinically important difference on these scales; the range of symptom scores used potentially also threatens the appropriateness of combining data in a meta-analysis. The variability in the effect of specific injection immunotherapy may be also explained by variable responses to treatment according to the type of allergen used, the quality of allergen vaccines used, the age of participants included in these trials, or the dose and duration of treatment given. Also, in this review, we found a lack of information in some of the studies in describing the optimal maintenance dose of major allergen; this is important to consider because studies suggest that therapeutic efficacy may require high allergen doses. (Low dose immunotherapy is usually ineffective (WHO 1998), therefore therapeutic efficacy correlates with an optimal maintenance dose in the range of 5 to $20 \mathrm{mcg}$ of major allergen per injection for a number of primary allergens).

The study also shows that the reported clinical benefits may translate into improvements in disease specific quality of life: the most recent studies have reported on outcomes using validated rhinitis quality of life questionnaires. Data relating to individual organ-specific symptom scores from a number of the studies also consistently point to the efficacy of immunotherapy (compared with placebo) in improving nasal, ocular and global symptom scores in patients with seasonal allergic rhinitis.

In addition, these trials have found strong and consistent evidence that immunotherapy results in favourable responses in a number of immunological outcomes, and although these data are of interest in terms of understanding the pathophysiology of the underlying disease process and the mechanisms of action of injection immunotherapy, their clinical significance remains unclear. The data raise the question whether such biomarkers may be surrogate and/or predictive of the clinical response to immunotherapy and therefore useful for monitoring immunotherapy. Larger controlled trials are required to test this possibility. Data on the cost-effectiveness of injection specific allergen immunotherapy represent an important omission in the reported trials and this data gap needs to be filled by future studies.

In this systematic review, there were no accepted studies of allergen injection immunotherapy that were conducted exclusively in children. Furthermore only nine studies extended the age range to participants younger than 18 years of age; one study included patients between 6 and 56 years of age (Karmaker 1994); however, no data assessing specific outcomes were reported in the younger participants.

We have found that patients treated with injection immunotherapy are at increased risk of both local and systemic adverse reactions. In the majority of cases, symptoms were readily reversible with appropriate treatment. This review shows that four events were categorized as 'early systemic reaction grade 4'; three reactions were described in the active treatment group (two cases of anaphylaxis and one case of exacerbation of asthma with oedema of glottis and hypotension) and one case in the placebo group (described as anaphylaxis). No further explanation was given regarding the clinical characteristics of these individuals. It was reported that all subjects fully recovered after adequate treatment and it is relevant that all continued with immunotherapy and none dropped out following these reactions. The number of participants involved in the trials varies from 18 to 410 . These numbers compare well with guidelines for Phase I, II and III clinical trials and provide useful information on the safety of the procedure under carefully controlled circumstances.

Although fatalities associated with the use of immunotherapy have been previously reported in the medical literature (CSM 1986; Reid 1993; Bernstein 2004; Aaronson 2004), these occurred almost exclusively in patients with co-existing asthma (16 of 17 in the CSM report). Furthermore, asthma was frequently poorly controlled (i.e. lability, required steroids, and/or prior hospitalisations) and there were additional risk factors. In the AAAAI report (Reid 1993), hay fever was reported in $53 \%$ ( 9 of 17) of the patients who died; eight of these patients had coexisting asthma, some also had diabetes and coronary vascular disease. Only one patient was reported to have had hay fever only, but he had coexisting hypertension, cardiovascular disease, and was receiving a B-blocker treatment. Delay or omission in the use of adrenaline in anaphylaxis, wrong selection of candidates for injection immunotherapy, dosing errors, no cardiorespiratory resuscitation facilities available and no adherence to immunotherapy practice guidelines can be responsible for these fatalities.

In the 13 out of 52 studies that reported that adrenaline was available for use, it was only given in seven of these 13 studies. In the seven studies where adrenaline was administered, there were 19 events in the active group and one event in the placebo group that were treated with this medication; this correspond to $0.13 \%$ of the 14,085 injections given in the active group and $0.01 \%$ of 8278 injections given in the placebo group (Figure 01). These data are likely to overestimate adrenaline usage since it is probable that in the majority of the 39 studies where adrenaline was not mentioned it is unlikely that it was used.

The reasons for adrenaline use varied; these include nasal and ocular itching, facial reddening, pharyngeal itching with cough, moderate wheezing, urticaria, angioedema. In three cases anaphylaxis was reported as the inciting event, although precise details not given. In some studies (Iliopoulos 1991 and Dolz 1996), adrenaline was given as a 'first choice' treatment and adverse events were not described as anaphylaxis. In many instances adrenaline appeared to have been given as a precautionary treatment and should not be regarded as a marker 'per se' of anaphylaxis. In the large multicentre study by Frew 2006 which included 307 subjects on active immunotherapy, and in whom full documentation of both early and delayed side effects were recorded in patient diary cards, there was no recorded use of adrenaline.

In conclusion, we have found that specific allergen injection immunotherapy is a safe and efficacious treatment in reducing symptom severity and the requirement for anti-allergic medication. Evaluating the clinical benefits of immunotherapy treatment and 
the tolerable nature of side effects, we can consider that the risk/ benefit ratio of injection immunotherapy favours treating patients with seasonal allergic rhinitis who have not responded to standard drugs, provided that potential risks and benefits are properly assessed and explained to the patient. In view of the occasional occurrence of systemic side effects following injections and the reported use of adrenaline to treat such reactions, it is important that injection immunotherapy is performed in the immediate presence of a physician and administered by personnel that are fully trained and who are experienced in the early recognition and treatment of such reactions.

\section{AUTHORS' CONCLUSIONS}

\section{Implications for practice}

Injection immunotherapy for grass pollen is effective in improving symptoms and reducing the need for medication in patients with seasonal allergic rhinitis and improves disease specific quality of life in these subjects. Whether the treatment is cost-effective remains to be determined.

There are significant risks associated with the use of injection immunotherapy including the rare occurrence of adverse events requiring adrenaline, but when administered in controlled clinical settings this risk is greatly reduced.
In summary, we conclude that injection immunotherapy is a safe and valid treatment option in patients with seasonal allergic rhinitis. It is particularly useful in those who fail to respond adequately to other treatments, provided that it is administered in settings in which patients can be monitored and, if necessary, promptly and effectively treated for systemic allergic reactions.

\section{Implications for research}

There is a need for studies to report trial procedures more clearly as detailed in the CONSORT (Junker 1996) statements and in particular to describe the randomisation technique employed. Validated outcome measures should be used wherever possible taking care to distinguish between statistical and clinical significance. Given the known risks, all trials should more explicitly record and publish information on adverse events. Finally, there is a pressing need for cost-effectiveness studies for what is a resource intensive intervention.

\section{ACK N O WLEDGEMENTS}

Our gratitude is extended to the authors of individual studies who provided additional data. Our thanks also to Jenny Bellorini and Carolyn Doree from the Cochrane ENT Group for excellent support. 


\section{R E F E R E N C E S}

\section{References to studies included in this review}

Alvarez-Cuesta 2005 \{published data only\}

Alvarez-Cuesta E, Aragoneses-Gilsanz E, Martin-Garcia C, Berges-Gimeno P, Gonzalez-Mancebo E, Cuesta-Herranz J. Immunotherapy with depigmented glutaraldehydepolymerized extracts: changes in quality of life. Clinical and Experimental Allergy 2005;35(5):572-8.

\section{Ariano 1999 \{published data only\}}

Ariano R, Kroon AM, Augeri G, Canonica GW, Passalacqua G. Long-term treatment with allergoid immunotherapy with Parietaria. Clinical and immunologic effects in a randomized, controlled trial.. Allergy 1999;54:313-9.

\section{Armentia-Medina 1989 \{published data only\}}

Armentia-Medina A, Blanco-Quiros A, Martin-Santos JM, AlvarezCuesta E, Moneo-Goiri I, Carreira P, et al. Rush immunotherapy with a standardized Bermuda grass pollen extract. Annals of Allergy 1989;63(2):127-35.

\section{Arvidsson 2002 \{published data only\}}

Arvidsson MB, Lowhagen O, Rak S. Effect of 2-year placebocontrolled immunotherapy on airway symptoms and medication in patients with birch pollen allergy. Journal of Allergy and Clinical Immunology 2002;109:777-83.

\section{Balda 1998 \{published data only\}}

Balda BR, Wolf H, Baumgarten C, Klimek L, Rasp G, Kunkel G, et al. Tree-pollen allergy is efficiently treated by short-term immunotherapy (SIT) with seven preseasonal injections of molecular standardized allergens. Allergy 1998;53(8):740-8.

\section{Bodtger 2002 \{published data only\}}

Bodtger U, Poulsen LK, Jacobi HH, Malling HJ. The safety and efficacy of subcutaneous birch pollen immunotherapy - a oneyear, randomised, double-blind, placebo-controlled study. Allergy 2002;57(4):297-305.

\section{Bousquet 1987a \{published data only\}}

Bousquet J, Hejjaoui A, Skassa-Brociek W, Guerin B, Maasch HJ, Dhivert $\mathrm{H}$, Michel FB. Double-blind, placebo-controlled immunotherapy with mixed grass-pollen allergoids. I. Rush immunotherapy with allergoids and standardized orchard grass-pollen extract. Journal of Allergy and Clinical Immunology 1987;80(4):591-8.

\section{Bousquet 1987b \{published data only\}}

Bousquet J, Frank E, Soussana M, Hejjaoui A, Maasch HJ, Michel FB. Double-blind, placebo-controlled immunotherapy with a high-molecular-weight, formalinized allergoid in grass pollen allergy. International Archives of Allergy and Applied Immunology 1987;82(3-4):550-2.

\section{Bousquet 1988 \{published data only\}}

Bousquet J, Maasch H, Martinot B, Hejjaoui A, Wahl, Michel FB. Double-blind, placebo-controlled immunotherapy with mixed grass-pollen allergoids. II Comparison between parameters assessing the efficacy of immunotherapy. Journal of Allergy and Clinical Immunology 1988;82(3 pt 1):439-46.

\section{Bousquet 1989 \{published data only\}}

Bousquet J, Maasch HJ, Hejjaoui A, Skassa-Brociek W, Wahl R, Dhivert $\mathrm{H}$, Michel FB. Double-blind, placebo-controlled immunotherapy with mixed grass-pollen allergoids. III Efficacy and safety of unfractionated and high-molecular-weight preparations in rhinoconjunctivitis and asthma. Journal of Allergy and Clinical Immunology 1989;84(4 pt 1):546-56.

\section{Bousquet 1990 \{published data only\}}

Bousquet J, Hejjaoui A, Soussana M, Michel FB. Double-blind, placebo-controlled immunotherapy with mixed grass-pollen allergoids. IV Comparison of the safety and efficacy of two dosages of a high-molecular-weight allergoid. Journal of Allergy and Clinical Immunology 1990;85(2):490-7.

\section{Bousquet 1991 \{published data only\}}

Bousquet J, Becker WM, Hejjaoui A, Chanal I, Lebel B, Dhivert H, Michel FB. Differences in clinical and immunologic reactivity of patients allergic to grass pollens and to multiple-pollen species. II. Efficacy of a double-blind, placebo-controlled, specific immunotherapy with standardized extracts. Journal of Allergy and Clinical Immunology 1991;88(1):43-53.

Brewczynski 1999 \{published data only\}

Brewczynski PZ, Kroon AM. Efficacy and safety of immunotherapy with modified grass pollen allergens. Results of a placebo-controlled study [Wirksamkeit und vertraglichkeit einer immuntherapie mit modifizierten graserpollenallergenen]. Allergologie 1999;22(7):411-20.

\section{Brunet 1992a \{published data only\}}

Brunet C, Bedard PM, Lavoie A, Jobin M, Hebert J. Allergic rhinitis to ragweed pollen. I. Reassessment of the effects of immunotherapy on cellular and humoral responses. Journal of Allergy and Clinical Immunology 1992;89(1pt 1):76-86.

Ceuppens 2004 \{published data only\}

Ceuppens J, Kleinjans H, van der Werf J, Rovers M, Stevens W, Jansen A, Zijlker T, Piessens M, Bruggink T, van Durme P. Immunotherapy with a depot birch pollen allergoid. A randomized double-blind placebo-controlled efficacy study [Abstract]. XXIII Congress of the European Academy of Allergology and Clinical Immunology (EAACI). Abstract no. 438. Amsterdam, the Netherlands, 12-16 June. 2004.

\section{Charpin 2003 \{published data only\}}

Charpin D, Dron M, Fardeau M, Massabie-Bouchat Y, Hugues B, Fabre C, et al. Clinical efficacy of Juniperus ashei specific immunotherapy in European Cypress rhinoconjunctivitis: a double-blind placebo-controlled trial [Abstract]. XXII Congress of the European Academy of Allergology and Clinical Immunology (EAACI). 2003.

Corrigan 2005 \{published data only\}

Corrigan CJ, Kettner J, Doemer C, Cromwell O, Narkus A Study Group. Efficacy and safety of preseasonal-specific 
immunotherapy with an aluminium-adsorbed six-grass pollen allergoid. Allergy 2005;60(6):801-7.

D'Amato 1995 \{published data only\}

D'Amato G, Kordash TR, Liccardi G, Lobefalo G, Cazzola M, Freshwater LL. Immunotherapy with Alpare in patients with respiratory allergy to Parietaria pollen: a two year double-blind placebo-controlled study. Clinical and Experimental Allergy 1995;25(2):149-58.

\section{Dolz 1996 \{published data only\}}

Dolz I, Martinez-Cocera C, Bartolome JM, Cimarra M. A doubleblind, placebo-controlled study of immunotherapy with grasspollen extract Alutard SQ during a 3-year period with initial rush immunotherapy. Allergy 1996;51:489-500.

\section{Drachenberg 2001 \{published data only\}}

Drachenberg KJ, Wheeler AW, Stuebner P, Horak F. A welltolerated grass pollen-specific allergy vaccine containing a novel adjuvant, monophosphoryl lipid $\mathrm{A}$, reduced allergic symptoms after only four preseasonal injections. Allergy 2001;56:498-505.

\section{Drachenberg 2002 \{published data only\}}

Drachenberg K, Heinzkill M, Urban E. Short-term immunotherapy with tree pollen allergoids and the adjuvant monophosphoryl lipid-A - Results from a multicentre, placebocontrolled, randomised, double-blind study. Allergologie 2002;25(9):466-74.

\section{Ferrer 2005 \{published data only\}}

Ferrer M, Burches E, Pelaez A, Munoz A, Hernandez D, Basomba A, et al. Double-blind, placebo-controlled study of immunotherapy with Parietaria judaica: clinical efficacy and tolerance. Journal of Investigational Allergology and Clinical Immunology 2005;15(4):283-92.

\section{Fling 1989 \{published data only\}}

Fling JA, Ruff ME, Parker WA, Whisman BA, Martin ME, Moss RB, Reid MJ. Suppression of the late cutaneous response by immunotherapy. Journal of Allergy and Clinical Immunology 1989;83(1):101-9.

\section{Frew 2006 \{published data only\}}

Frew AJ, Powell RJ, Corrigan CJ, Durham SR, on behalf of the UK Immunotherapy Study Group. Efficacy and safety of specific immunotherapy with SQ allergen extract in treatment-resistant seasonal allergic rhinoconjunctivitis. Journal of Allergy and Clinical Immunology 2006;117:319-25.

\section{Grammer 1982 \{published data only\}}

Grammer LC, Zeiss CR, Suszko IM, Shaughnessy MA, Patterson R. A double-blind, placebo-controlled trial of polymerized whole ragweed for immunotherapy of ragweed allergy. Journal of Allergy and Clinical Immunology 1982;69(6):494-9.

\section{Grammer 1983 \{published data only\}}

Grammer LC, Shaughnessy MA, Suszko IM, Shaughnessy JJ, Patterson R. A double-blind histamine placebo-controlled trial of polymerized whole grass for immunotherapy of grass allergy. Journal of Allergy and Clinical Immunology 1983;72:448-53.

\section{Grammer 1984a \{published data only\}}

Grammer LC, Shaughnessy MA, Suszko IM, Shaughnessy JJ, Patterson R. Persistence of efficacy after a brief course of polymerized ragweed allergen: a controlled study. Journal of Allergy and Clinical Immunology 1984;73(4):484-9.

Grammer 1984b \{published data only\}

Grammer LC, Shaughnessey MA, Shaughnessy JJ, Patterson R. Asthma as a variable in a study of immunotherapy for allergic rhinitis. Journal of Allergy and Clinical Immunology 1984;73(5 Pt 1):557-60.

\section{Grammer 1986 \{published data only\}}

Grammer LC, Shaughnessy MA, Finkle SM, Shaughnessy JJ, Patterson R. A double-blind placebo-controlled trial of polymerized whole grass administered in an accelerated dosage schedule for immunotherapy of grass pollinosis. Journal of Allergy and Clinical Immunology 1986;78:1180-4.

\section{Grammer 1987 \{published data only\}}

Grammer LC, Shaughnessy MA, Bernhard MI, Finkle SM, Pyle HR, Silvestri L, Patterson R. The safety and activity of polymerized ragweed: a double-blind, placebo-controlled trial in 81 patients with ragweed rhinitis. Journal of Allergy and Clinical Immunology 1987;80(2):177-83.

\section{Hauser 1995 \{published data only\}}

Hauser U, Bachert C, Frank E. Inhibitory effect on migration of inflammatory cells into the nasal mucosa by immunotherapy [Hemmung des einstroms von entzundungszellen in die nasenschleimhaut durch die allergen-spezifische immuntherapie]. Allergo Journal 1995;4:164-71.

\section{Hauser 1997 \{published data only\}}

Hauser U, Wagenmann M, Rudack C, Cromwell O, Ganzer U. Specific immunotherapy suppresses IL-1beta and IL-8 levels in nasal secretions: A possible explanation for the inhibition of inflammatory cell migration [Die spezifische immuntherapie reduziert il-1beta und il-8-konzentrationen im nasensekret - eine mogliche erklarung der hammung der einwanderung von entzundungszellen in die nasenschleimhaut]. Otorhinolaryngologia Nova 1997;7(1):31-9.

\section{Iliopoulos 1991 \{published data only\}}

Iliopoulos O, Proud D, Adkinson NJ, Creticos PS, Norman PS, Kagey S, Lichtenstein LM, Naclerio RM. Effects of immunotherapy on the early, late, and rechallenge nasal reaction to provocation with allergen: changes in inflammatory mediators and cells. Journal of Allergy and Clinical Immunology 1991;87(4):855-66.

\section{Juniper 1985 \{published data only\}}

Juniper EF, Roberts RS, Kennedy LK, O'Connor J, Syty GM, Dolovich J, Hargreave FE. Polyethylene glycol-modified ragweed pollen extract in rhinoconjunctivitis. Journal of Allergy and Clinical Immunology 1985;75(5):578-85.

\section{Jutel 2005 \{published data only\}}

Jutel M, Jaeger L, Suck R, Meyer H, Fiebig H, Cromwell O. Allergen-specific immunotherapy with recombinant grass 
pollen allergens. Journal of Allergy and Clinical Immunology 2005;116(3):608-13.

\section{Karmaker 1994 \{published data only\}}

Karmakar PR, Das A, Chatterjee BP. Placebo-controlled immunotherapy with Cocos nucifera pollen extract. International Archives of Allergy and Immunology 1994;103(2):194-201.

\section{Lee 1982 \{published data only\}}

Lee LK, Kniker WT, Campos T. Aggressive coseasonal immunotherapy in mountain cedar pollen allergy. Archives of Otolaryngology 1982;108(12):787-94.

\section{Leynadier 2001 \{published data only\}}

Leynadier F, Banoun L, Dollois B, Terrier P, Epstein M, Guinnepain MT, et al. Immunotherapy with calcium phosphate-adsorbed five-grass-pollen extract in seasonal rhinoconjunctivitis: a double-blind, placebo-controlled study. Clinical and Experimental Allergy 2001;31:988-96.

\section{Litwin 1991 \{published data only\}}

Litwin A, Pesce AJ, Fischer T, Michael M, Michael JG. Regulation of the human immune response to ragweed pollen by immunotherapy. A controlled trial comparing the effect of immunosuppressive peptic fragments of short ragweed with standard treatment. Clinical and Experimental Allergy 1991;21(4):457-65.

\section{Meriney 1986 \{published data only\}}

Meriney DK, Kothari H, Chinoy P, Grieco MH. The clinical and immunologic efficacy of immunotherapy with modified ragweed extract (allergoid) for ragweed hay fever. Annals of Allergy 1986;56(1):34-8.

\section{Metzger 1981 \{published data only\}}

Metzger WJ, Clay DH, Richerson HB, Weiler JM, Donnelly A, Moran D. Clinical and immunologic evaluation of glutaraldehyde-modified, tyrosine-adsorbed short ragweed extract: A double-blind, placebo-controlled trial. Journal of Allergy and Clinical Immunology 1981;68(6):442-8.

\section{Mirone 2004 \{published data only\}}

Mirone C, Albert F, Tosi A, Mocchetti F, Mosca S, Giorgino M, Pecora S, Parmiani S, Ortolani C. Efficacy and safety of subcutaneous immunotherapy with a biologically standardized extract of Ambrosia artemisiifolia pollen: a double-blind, placebo-controlled study. Clinical and Experimental Allergy 2004;34(9):1408-14.

\section{Norman 1982 \{published data only\}}

Norman PS, Lichtenstein LM, Kagey-Sobotka A, March DG. Controlled evaluation of allergoid in the immunotherapy of ragweed hay fever. Journal of Allergy and Clinical Immunology 1982;70:248-60.

\section{Ortolani 1984 \{published data only\}}

Ortolani C, Pastorello E, Moss RB, Hsu YP, Restuccia M, Joppolo G, et al. Grass pollen immunotherapy: a single year double-blind, placebo-controlled study in patients with grass pollen-induced asthma and rhinitis. Journal of Allergy and Clinical Immunology 1984;73(2):283-90.

Ortolani 1994 \{published data only\}

Ortolani C, Pastorello EA, Incorvaia C, Ispano M, Farioli L, Zara C, Pravettoni V, Zanussi C. A double-blind, placebo-controlled study of immunotherapy with an alginate-conjugated extract of Parietaria judaica in patients with Parietaria hay fever. Allergy 1994;49:13-21.

\section{Paraskevopoulos 2005 \{published data only\}}

Paraskevopoulos G, Jacobson M, Carr V, Calderon M, Till S, Francis J, Durham S. Grass pollen injection immunotherapy: time course of suppression of allergen-induced late-phase skin responses [Abstract]. Journal of Allergy and Clinical Immunology 2005;115(2 (Suppl 1)):S266.

\section{Parker 1989 \{published data only\}}

Parker WJ, Whisman B, Apaliski S, Reid M. The relationships between late cutaneous responses and specific antibody responses with outcome of immunotherapy for seasonal allergic rhinitis. Journal of Allergy and Clinical Immunology 1989;84(5 (Pt 1)):667-77.

\section{Pastorello 1992 \{published data only\}}

Pastorello EA, Pravettoni V, Incorvaia C, Mambretti M, Franck E, Wahl R, Zanussi C. Clinical and immunological effects of immunotherapy with alum-absorbed grass allergoid in grasspollen-induced hay fever. Allergy 1992;47:281-90.

\section{Tari 1997 \{published data only\}}

Tari MG, Mancino M, Ghezzi E, Frank E, Cromwell O. Immunotherapy with an alum-adsorbed Parietaria-pollen allergoid: a 2-year, double-blind, placebo-controlled study. Allergy 1997;52(1):65-74.

\section{Varney 1991 \{published data only\}}

Varney VA, Gaga M, Frew AJ, Aber VR, Kay AB, Durham SR. Usefulness of immunotherapy in patients with severe summer hay fever uncontrolled by antiallergic drugs. British Medical Journal 1991;302(6771):265-9.

\section{Walker 2001 \{published data only\}}

Walker SM, Pajno GB, Torres-Lima M, Wilson DR, Durham SR. Grass pollen immunotherapy for seasonal rhinitis and asthma: a randomized, controlled trial. Journal of Allergy and Clinical Immunology 2001;107:87-93.

\section{Zenner 1997 \{published data only\}}

Zenner HP, Baumgarten C, Rasp G, Fuchs T, Kunkel G, Hauswald B, et al. Short-term immunotherapy: A prospective, randomized, double-blind, placebo-controlled multicenter study of molecular standardized grass and rye allergens in patients with grass pollen-induced allergic rhinitis. Journal of Allergy and Clinical Immunology 1997;100:23-9.

\section{References to studies excluded from this review}

\section{Aabel 2000 \{published data only\}}

Aabel S, Laerum E, Dolvik S, Djupesland P. Is homeopathic 'immunotherapy' effective? A double-blind, placebo-controlled 
trial with the isopathic remedy Betula $30 \mathrm{c}$ for patients with birch pollen allergy. British Homoeopathic Journal 2000;89(4):161-8.

\section{Adelroth 1999 \{published data only\}}

Adelroth E, Sandstrom T, Rak S, Rosenhall L, Zetterstrom O, Aasand O, et al. rhuMAb-E25 (E25) improves quality of life in patients with birch pollen induced seasonal allergic rhinitis. European Respiratory Society. 1999.

\section{Adelroth 2000 \{published data only\}}

Adelroth E, Rak S, Haahtela T, Aasand G, Rosenhall L, Zetterstrom O, et al. Recombinant humanized mAb-E25, an anti-IgE mAb, in birch pollen-induded seasonal allergic rhinitis. Journal of Allergy and Clinical Immunology 2000;106:253-9.

Ancill 1990 \{published data only\}

Ancill R, Takahashi Y, Kibune Y, Campbell R, Smith J. Randomized double-blind, placebo-controlled clinical trial of a selective 5-lipoxygenase inhibitor (AA-861) for the prevention of seasonal allergic rhinitis. Journal of International Medical Research 1990;18(2):75-88.

\section{Andre $\mathbf{2 0 0 0}$ \{published data only\}}

Andre C, Vatrinet C, Galvain S, Carat F, Sicard H. Safety of sublingual-swallow immunotherapy in children and adults. International Archives of Allergy and Immunology 2000;121:229-34.

\section{Astarita 1996 \{published data only\}}

Astarita C, Scala G, Sproviero S, Franzese A. Effects of enzymepotentiated desensitization in the treatment of pollinosis: A double-blind placebo-controlled trial. Journal of Investigational Allergology and Clinical Immunology 1996;6(4):248-55.

\section{Bacal 1978 \{published data only\}}

Bacal E, Zeiss C, Suszko I, et al. Polymerized whole ragweed: An improved method of immunotherapy. Journal of Allergy and Clinical Immunology 1978;62(5):289-94.

\section{Barrett 2000 \{published data only\}}

Barrett J, King M, Pang G. Conditioning rhinitis in allergic humans. Annals of the New York Academy of Sciences 2000;917:853-9.

\section{Berkovitz 2005 \{published data only\}}

Berkovitz, SR. Double blind randomised parallel group placebo controlled study to evaluate the efficacy of enzyme potentiated desensitisation (EPD) in seasonal rhinitis. National Research Register 2005.

\section{Bernstein 1976 \{published data only\}}

Bernstein I, Tennenbaum J, Georgakis N, Kessler F, Krumholz R. Fraction A: a new immunotherapeutic approach for ragweed pollinosis. International Archives of Allergy and Applied Immunology 1976;50(2):181-91.

\section{Berstein 2001 \{published data only\}}

Berstein C, Deng C, Shuklah R, Berstein J, Bernstein I, Bernstein D. Double blind placebo controlled (DBPC) study of grapeseed extract in the treatment of seasonal allergic rhinitis
(SAR). Journal of Allergy and Clinical Immunology 2001;107(2 (Pt 2)):S311.

\section{Bochenska 2003 \{published data only\}}

Bochenska-Marciniak M, Kupczyk M, Gorski P, Kuna P. The effect of recombinant interleukin-8 on eosinophils' and neutrophils' migration in vivo and in vitro. Allergy 2003;58(8):795-801.

\section{Bodtger 2003 \{published data only\}}

Bodtger U, Poulsen L, Malling H-J. Retrospective assessment of seasonal allergic symptoms: Over-rating but useful. Clinical and Experimental Allergy 2003;33(4):496-500.

\section{Bolhaar 2004 \{published data only\}}

Bolhaar S, Tiemessen M, Zuidmeer L, van Leeuwen A, Hoffmann-Sommergruber K, Bruijnzeel-Koomen C, et al. Efficacy of birch-pollen immunotherapy on cross-reactive food allergy confirmed by skin tests and double-blind food challenges. Clinical and Experimental Allergy 2004;34(5):761-9.

\section{Bonifazi 1991 \{published data only\}}

Bonifazi F, Antonicelli L, Bilo M, Pucci S, Taylor I, Wheeler A, Youlten L. Hyposensitization therapy of Parietaria-sensitive patients with a tyrosine adsorbed allergoid, Pollinex Parietaria (Bencard Parietaria). Journal of Investigational Allergology and Clinical Immunology 1991;1(1):37-44.

\section{Boznanski 1996 \{published data only\}}

Boznanski A, Willak-Janc E, Domanasiewicz M, Pirogowicz I, Widerska A. Evaluation of soluble components of receptors with weak affinity for IgE (sCD23) in children with pollinosis given specific immunotherapy [Ocena rozpuszczalnej skladowej receptora o slabym powinowactwie dla IgE (sCD23) u dzieci z pylkowica poddanych immunoterapii swoistej]. Pneumonologia i Alergologia Polska 1996;64(7-8):386-91.

Brown 1964 \{published data only\}

Brown EB, Ipsen J, Popovits C. Use of poisonoak extract in ragweed hay fever. A double-blind study. NY State J Med 1964;64:2050-3.

\section{Bruce 1997 \{published data only\}}

Bruce CA, Norman PS, Rosenthal RR, Lichtenstein LM. The role of ragweed pollen in autumnal asthma. Journal of Allergy and Clinical Immunology 1977;59(6):449-59.

\section{Brunet 1992b \{published data only\}}

Brunet C, Bedard P, Lavoie A, Jobin M, Hebert J. Allergic rhinitis to ragweed pollen. II. Modulation of histamine-releasing factor production by specific immunotherapy. Journal of Allergy and Clinical Immunology 1992;89(1 (Pt 1)):87-94.

\section{Bruno 1986 \{published data only\}}

Bruno G, Wuthrich B, Ganderton M, et al. A multicenter trial of immunotherapy with alginate-conjugated grass pollen extract. Annals of Allergy 1986;56(5):384-91.

\section{Caffarelli 2000 \{published data only\}}

Caffarelli C, Sensi LG, Marcucci F, Cavagni G. Preseasonal local allergoic immunotherapy to grass pollen in children: a 
double-blind, placebo-controlled, randomized trial. Allergy 2000;55:1142-7.

\section{Calderon 2003 \{published data only\}}

Calderon M, Durham S, Frew A. Double blind placebo controlled study of specific immunotherapy (SIT) with Alutard SQ grass pollen for seasonal allergic rhinoconjunctivitis. Allergy and Clinical Immunology International 2003;1 (Suppl 1):Abstract No. 0-14-1.

\section{Cantani 1984 \{published data only\}}

Cantani A, Businco E, Benincori N, et al. A three year controlled study in children with pollinosis treated with immunotherapy. Annals of Allergy 1984;53(1):79-84.

\section{Caramia 1996 \{published data only\}}

Caramia G, Franceschini F, Cimarelli Z, Ciucchi M, Gagliardini R, Ruffini E. The efficacy of E.P.D., a new immunotherapy, in the treatment of allergic diseases in children. Allergologie et Immunologie Paris 1996;28(9):308-10.

\section{Charpin 1985 \{published data only\}}

Charpin D, Poisson A, Charpin J. The advantages of triple dose histaglobin in the symptomatic treatment of pollinosis. Revue Francaise d'Allergologie et d'Immunologie Clinique 1985;25(2):103-5.

\section{Chyrek-Borowska 1995 \{published data only\}}

Chyrek-Borowska S, Rogalewska A, Szymanski W, Zlotnik I, Michalska I. Efficacy and tolerance of allergenic extracts Allergovit and Novo-Helisen depot in immunotherapy of allergic diseases [Skutecznosc i tolerancja preparatów alergenowych allergovit i novo- helisen depot w immunoterapii chorób alergicznych]. Pneumonologia I Alergologia Polska 1995;63(Suppl 2):32-41.

\section{Cirla 1996 \{published data only\}}

Cirla AM, Sforza N, Roffi GP, Alessandrini A, Stanizzi R, Dorigo N, Sala E, Della Torre F. Preseasonal intranasal immunotherapy in birch-alder allergic rhinitis. Allergy 1996;51:299-305.

\section{Cockcroft 1977 \{published data only\}}

Cockcroft DW, Cuff MT, Tarlo SM, Dolovich J, Hargreave FE. Allergen injection therapy with glutaraldehyde-modifiedragweed pollen-tyrosine adsorbate. Journal of Allergy and Clinical Immunology 1977;60(1):56-62.

\section{Connell 1967 \{published data only\}}

Connell J, Sherman W. Hay fever symptoms related to immunological findings. Annals of Allergy 1967;25(5):239-50.

\section{Creticos 1996 \{published data only\}}

Creticos PS, Reed CE, Norman PS, Khoury J, Adkinson NF, et al. Ragweed immunotherapy in adult asthma. New England Journal of Medicine 1996;334(8):501-6.

\section{Creticos 2003 \{published data only\}}

Creticos P, Lighvani S, Bieneman A, Balcer-Whaley S, Norman P, Lichtenstein L, Schroeder J. Enhanced IL-10 secretion by PBMC during the ragweed season: effect of AIC immunotherapy vs placebo. Journal of Allergy and Clinical Immunology 2003;111(2 (Pt 2)):S201.

\section{Crimi 2001 \{published data only\}}

Crimi N, et al. A randomised double-blind study of specific immunotherapy (SIT) in patients with seasonal allergicrhinitis: effects on clinical and inflammatory markers. European Respiratory Journal 2001;18(Suppl 33):482s.

D'Amato 1996 \{published data only\}

D'Amato G, Liccardi G, Russo M, Saggese M, D'Amato M. Measurement of serum levels of eosinophil cationic protein to monitor patients with seasonal respiratory allergy induced by Parietaria pollen (treated and untreated with specific immunotherapy).. Allergy 1996;51(4):245-50.

Demoly 2002 \{published data only\} Demoly P, Persi L, Dhivert H, Delire M, Bousquet J. Immunotherapy with keyhole lampet hemocyanin-conjugated decapeptide vaccine in cypress pollen allergy. Clinical and Experimental Allergy 2002;32(7):1071-6.

\section{Di Stanislao 1997 \{published data only\}}

Di Stanislao C, Di Berardino L, Bianchi I, Bologna G. A doubleblind, placebo-controlled study of preventive immunotherapy with E.P.D., in the treatment of seasonal allergic disease. Allergie et Immunologie 1997;30:39-42.

\section{Dokic 1996 \{published data only\}}

Dokic D, Nethe A, Kleine-Tebbe J, Kunkel G, Baumgarten C. Mediator release is altered in immunotherapy-treated patients: a 4-year study. Allergy 1996;51(11):796-803.

\section{Donat 1981 \{published data only\}}

Donat N, Doinel C. Clinical efficacy and changes in specific immunoglobulins after desensitisation to grass pollens over two pollen seasons. Revue Francaise d'Allergologie et d'Immunologie Clinique 1982;22:7-13.

\section{Donovan 1996 \{published data only\}}

Donovan JP, Buckeridge DL, Briscoe MP, Clark RH, Day JH. Efficacy of immunotherapy to ragweed antigen tested by controlled antigen exposure. Annals of Allergy, Asthma and Immunology 1996;77:74-80.

\section{Dorward 1984 \{published data only\}}

Dorward A, Waclawski E, Kerr J. A comparison of the clinical and immunological effects of an alum-precipitated five-grass extract with a conjugated two-grass extract in the desensitization of hay fever. Clinical Allergy 1984;14(6):561-70.

\section{Durham 1991 \{published data only\}}

Durham SR, Varney V, Gaga M, Frew AJ, Jacobson M, Kay AB. Immunotherapy and allergic inflammation. Clinical and Experimental Allergy 1991;21 (Suppl 1):206-10.

\section{Durham 1996 \{published data only\}}

Durham S, Ying S, Varney V, Jacobson M, Sudderick R, Mackay I, Kay A, Hamid Q. Grass pollen immunotherapy inhibits allergeninduced infiltration of CD4+ T lymphocytes and eosinophils in the nasal mucosa and increases the number of cells expressing 
messenger RNA for interferon-gamma. Journal of Allergy and Clinical Immunology 1996;97(6):1356-65.

\section{Durham 1999 \{published data only\}}

Durham SR, Walker SM, Varga E-M, Jacobson MR, O'Brien F, Noble W, et al. Long-term clinical efficacy of grasspollen immunotherapy. New England Journal of Medicine 1999;341(7):468-75.

\section{Durham 1999a \{published data only\}}

Durham SR, Varney A, Gaga M, Jacobson MR, Varga EM, Frew AJ, Kay AB. Grass pollen immunotherapy decreases the number of mast cells in the skin. Clinical and Experimental Allergy 1999;29:1490-6.

\section{Dykewicz 1998 \{published data only\}}

Dykewicz MS, Fineman S, Skoner DP, Nicklas R, et al. Diagnosis and management of rhinitis: complete guidelines of the Joint Task Force and practice parameters in allergy, asthma and immunology. Annals of Allergy, Asthma and Immunology 1998;81:478-518.

\section{Egger 1997 \{published data only\}}

Egger S, Klimek L. The influence of hypo-sensitisation therapy on the sense of smell in subjects with seasonal allergic rhinitis [Der Einfluss der Hyposensibilisierungstherapie auf das Riechvermogen bei saisonaler Rhinitis allergica.]. Allergologie 1997;20(10):525-7.

\section{Eng 2006 \{published data only\}}

Eng PA, Borer-Reinhold M, Heijnen IA, Gnehm HP. Twelve-year follow-up after discontinuation of preseasonal grass pollen immunotherapy in childhood. Allergy 2006;61:198-201.

\section{Eriksson 1979 \{published data only\}}

Eriksson N, Ahlstedt S, Lovhagen O. Immunotherapy in spring-time hay fever. A clinical and immunological study comparing two different treatment extract compositions. Allergy 1979;34(4):233-47.

\section{Fal 2002 \{published data only\}}

Fal A, Gietkiewicz K, Obojski A, Medrala W, Malolepszy J. The influence of a three-year preseasonal specific immunotherapy on selected parameters of allergic inflammation in pollinosis patients [Wplyw trzyletniej przedsezonowej immunoterapii swoistej na wybrane parametry zapalenia alergicznego u chorych na pylkowice]. Pneumonologia i Alergologia Polska 2002;70(1-2):78-86.

\section{Fell 1990 \{published data only\}}

Fell P, Brostoff J. A single dose desensitization for summer hay fever. Results of a double blind study-1988. European Journal of Clinical Pharmacology 1990;38(1):77-9.

\section{Fontana 1966 \{published data only\}}

Fontana V, Holt LJ, Mainland D. Effectiveness of hyposensitization therapy in ragweed hay-fever in children. Journal of the American Medical Association 1966;195(12):985-92.

\section{Frankland 1954 \{published data only\}}

Frankland AW, Augustin R. Prophylaxis of summer hay-fever and asthma. The Lancet 1954;(May 22):1055-7.

Frankland 1963 \{published data only\}

Frankland A, Blair Macaulay D, Gwyn Evans R. Treatment of hay fever by depot injection (shypyrindene) in allergic conditions. Double blind clinical study. Acta Allergologica 1963;18:175-6.

Franklin 1967 \{published data only\}

Franklin W, Lowell F. Comparison of two dosages of ragweed extract in the treatment of pollinosis. Journal of the American Medical Association 1967;201(12):915-7.

\section{Frostad 1980 \{published data only\}}

Frostad A, Grimmer O, Sandvik L, Aas K. Hyposensitization. Comparing a purified (refined) allergen preparation and a crude aqueous extract from timothy pollen. Allergy 1980;35(2):81-95.

Frostad 1983 \{published data only\}

Frostad A, Grimmer O, Sandvik L, Moxnes A, Aas K. Clinical effects of hyposensitization using a purified allergen preparation from Timothy pollen as compared to crude aqueous extracts from Timothy pollen and a four-grass pollen mixture respectively. Clinical Allergy 1983;13(4):337-57.

Furin 1991 \{published data only\}

Furin M, Norman P, Creticos P, Proud D, Kagey-Sobotka A, Lichtenstein L, Naclerio R. Immunotherapy decreases antigeninduced eosinophil cell migration into the nasal cavity. Journal of Allergy and Clinical Immunology 1991;88(1):27-32.

Gabriel 1977 \{published data only\}

Gabriel M, Ng H, Allan W, Hill L, Nunn A. Study of prolonged hyposensitization with $D$. pteronyssinus extract in allergic rhinitis. Clinical Allergy 1977;7(4):325-39.

Galvain 1999 \{published data only\} Galvain S, Andre C, Vatrinet C, Villet B. Safety and efficacy of liposomes in specific immunotherapy. Current Therapeutic Research, Clinical and Experimental 1999;60(5):278-94.

\section{Garcia Gonzalez 2002 \{published data only\}}

Garcia Gonzalez J, Bartolome Zavala B, Fernandez-Melendez S, Barcelo Munoz J, Miranda Paez A, Carmona Bueno M, et al. Occupational rhinoconjunctivitis and food allergy because of aniseed sensitization. Annals of Allergy, Asthma and Immunology 2002;88(5):518-22.

\section{Garcia-Selles 2003 \{published data only\}}

Garcia-Selles J, Pascual A, Funes E, Pagan J, Lopez J, Negro J, Hernandez J. Clinical efficacy and safety of a depigmented and glutaraldehyde polymerized therapeutic vaccine of Parietaria judaica. Allergologia et Immunopathologia 2003;31(2):63-9.

\section{Gehlhar 1998 \{published data only\}}

Gehlhar K, Schlaak M, Becker WM, Bufe A. Monitoring allergen immunotherapy of pollen allergic patients: the ratio of allergenspecific IgG4 to IgG1 correlates with clinical outcome. Clinical and Experimental Allergy 1999;29:497-506. 
Gietkiewicz 2001 \{published data only\}

Gietkiewicz K, Fal A, Malolepszy J. Evaluation of effectiveness and safety of three year immunotherapy with mixed grass pollen allergens [Ocena skutecznoSci klinicznej i bezpieczenstwa trzyletniej immunoterapii mieszanka alergenow pylkow traw]. Polskie Archiwum Medycyny Wewnetrznej 2001;106(6):1163-8.

\section{Giovannini 2005 \{published data only\}}

Giovannini M, Braccioni F, Sella G, Contoli M, Perri G, Frati F, Incorvaia C. Comparison of allergen immunotherapy and drug treatment in seasonal rhinoconjunctivitis: a 3-years study. Allergie et Immunologie 2005;37(2):69-71.

\section{Girard 1988 \{published data only\}}

Girard J, el Habib G, Granjard P. Treatment of hay fever by Allerglobuline: a randomized double-blind study. Clinical Allergy 1988;18(4):393-400.

\section{Gonzalez 2002 \{published data only\}}

Gonzalez P, Florido F, Saenz de San Pedro B, De la Torre F, Rico P, Martin S. Immunotherapy with an extract of Olea europaea quantified in mass units: Evaluation of the safety and efficacy after one year of treatment. Journal of Investigational Allergology and Clinical Immunology 2002;12(4):263-71.

\section{Goor 1971 \{published data only\}}

Goor W, Wuthrich B. Specific therapy of pollinosis. Results of desensitization with two different semi-depot allergen extracts (Allpyral and Suspal) [Zur spezifischen therapie der pollinosis.]. Schweizerische Medizinische Wochenschrift. Journal Suisse de Medecine 1971;101(33):1217-21.

\section{Gordon 1972 \{published data only\}}

Gordon V, Caplinger K, Meade JJ, Thompson C. Correlation of type specific fluorescent antibodies to ragweed with symptomatology: double-blind study. Annals of Allergy 1972;30(9):507-17.

\section{Grammer 1985 \{published data only\}}

Grammer L, Shaughnessy M, Shaughnessy J, et al. Allergenicity, immunogenicity, and safety of immunotherapy with various molecular weight ranges of polymerized ragweed. Journal of Allergy and Clinical Immunology 1985;76(21):195-200.

\section{Guardia 2004 \{published data only\}}

Guardia P, Moreno C, Justicia J, Conde J, Cimarra M, Diaz M, Guerra F, Martinez-Cocera C, Gonzalo-Garijo M, PerezCalderon R, Gonzalez-Quevedo T, Sanchez-Cano M, Vigaray J, Acero S, Blanco R, Martin S, de la Torre F. Tolerance and short-term effect of a cluster schedule with pollen-extracts quantified in mass-units. Allergologia et Immunopathologia 2004;32(5):271-7.

\section{Haahtela 1984 \{published data only\}}

Haahtela T, Wihl J, Munch E, et al. Hyposensitization in hay fever with grass pollen extracts: A three-year study comparing a dialysed alum adsorbed extract with Allpyra ${ }^{\circledR}$. Annals of Allergy 1984;52(5):355-62.

\section{Hauser 2003 \{published data only\}}

Hauser R, Rice T, Krishna Murthy G, Wand M, Lewis D, Bledsoe T, Paulauskis J. The upper airway response to pollen is enhanced by exposure to combustion particulates: a pilot human experimental challenge study. Environmental Health Perspectives 2003;111(4):472-7.

Hayashi 1998 \{published data only\}

Hayashi M, Ohashi Y, Tanaka A, Kakinoki Y, Nakai Y. Suppression of seasonal increase in serum interleukin-5 is linked to the clinical efficacy of immunotherapy for seasonal allergic rhinitis. Acta Oto-Laryngologica Supplement 1998;538:133-42.

Hendrix 1980 \{published data only\}

Hendrix SG, Patterson R, Zeiss R, Pruzansky JJ, Suszko IM, McQueen RC, et al. A multi-institutional trial of polymerised whole ragweed for immunotherapy of ragweed allergy. Journal of Allergy and Clinical Immunology 1980;66(6):486-94.

Hill 1982 \{published data only\}

Hill DJ, Hosking CS, Shelton MJ, Turner MW. Failure of hyposensitisation in treatment of children with grass-pollen asthma. British Medical Journal 1982;284:306-9.

\section{Hofman 1997a \{published data only\}}

Hofman T. Results of specific immunotherapy with Allergovit in patients with pollen allergy [Wyniki swoistej immunoterapii preparatem Allergovit chorych z alergia pylkowa.]. Polskie Merkuriusz Lekarski 1997;3(16):183-6.

\section{Hofman 1997b \{published data only\}}

Hofman T, Buczylko K, Brewczynski P, Kolasinska B. Evaluation of the efficacy of immunotherapy with allergovit and catalet in patients with hay fever--multidrug evaluations. Pneumonologia i Alergologia Polska 1997;65(1-2):65-70.

\section{Horak 1980 \{published data only\}}

Horak F, Jager S, Skoda-Turk R. Reduced allergen immunotherapy of grass pollinosis (author's transl) [Allergenreduzierte Immuntherapie bei Graserpollinose]. Wiener Klinische Wochenschrift 1980;Suppl 117:36-8.

\section{Ipsen 1988 \{published data only\}}

Ipsen H, Schwartz B, Wihl J, Petersen B, Munch E, Janniche H, Lowenstein $\mathrm{H}$. Immunotherapy with partially purified and standardized tree pollen extracts. III. Specific IgE response to the major allergens of alder, birch and hazel pollen during immunotherapy. Allergy 1988;43(5):370-7.

\section{Ito 1996 \{published data only\}}

Ito H, Suzuki M, Mamiya S, Takagi I, Baba S. Study on changes in the level of serum IL-4 and soluble CD 23(s-CD23) with immunotherapy in nasal allergy patients. Acta Otolaryngologica Supplement 1996;525(Suppl):98-104.

\section{Johansson 1974 \{published data only\}}

Johansson S, Miller A, Mullan N, Overell B, Tees E, Wheeler A. Glutaraldehyde-pollen-tyrosine: clinical and immunological studies. Clinical Allergy 1974;4(3):255-63. 
Juniper 1986 \{published data only\}

Juniper E, O'Connor J, Roberts R, Evans S, Hargreave F, Dolovich J. Polyethylene glycol-modified ragweed extract: comparison of two treatment regimens. Journal of Allergy and Clinical Immunology 1986;78(5 (Pt 1)):851-6.

Kakinoki 2000 \{published data only\}

Kakinoki Y, Ohashi Y, Nakai Y, Tanaka A, Washio Y. Pollen immunotherapy inhibits T helper 1 and 2 cell responses, but suppression of Thelper 2 cell response is a more important mechanism related to the clinical efficacy. Archives of Otolaryngology - Head and Neck Surgery 2000;126(1):63-70.

\section{Karlsson 1986 \{published data only\}}

Karlsson R, Agrell B, Dreborg S, Foucard T, Kjellman NIM, Koivikko A, Einarsson R. A double-blind, multicenter immunotherapy trial in children, using a purified and standardized Cladosporium herbarum preparation. Allergy 1986;41:141-50.

\section{Kasatkin 1976 \{published data only\}}

Kasatkin I, Kovtiukh L, Ametov A, Romanenko A. Clinical study of methods for determining immunoglobulin $E$ in allergy. Klinicheskaia Meditsina 1976;54(8):67-72.

\section{Kemker 1999 \{published data only\}}

Kemker BJ, Corey JP, Branca J, Gliklich RE. Development of the allergy outcome survey for allergic rhinitis. Otolaryngology Head and Neck Surgery 1999;121:603-5.

Kerr 1963 \{published data only\}

Kerr JW, Murchison LE. A controlled trial of pollen adsorbate in the treatment of hay fever. Scottish Medical Journal 1963;8:485-8.

\section{Kerr 1964 \{published data only\}}

Kerr J. The treatment of hay fever including a controlled trial of the use of alum precipitate pollen adsorbate. Acta Allergologica 1964;19:76-77.

\section{Keskin 2004 \{published data only\}}

Keskin O, Tuncer A, Kalayci O, Adalioglu G, Sekerel B, Sackesen C, Civelek E. The early effects of pre-seasonal grass pollen allergoid immunotherapy on bronchial hyperresponsiveness, symptom-medication scores and ECP levels in children with allergic rhinitis. XXIII Congress of the European Academy of Allergology and Clinical Immunology (EAACI). 2004.

\section{Keskin 2005 \{published data only\}}

Keskin O, Tuncer A, Yildirim S, Bursali B, Adalioglu G, Sekerel BE. Does specific immunotherapy injection cause an increase in bronchial reactivity?. The Journal of Asthma: Official Journal of the Association for the Care of Asthma 2005;42(9):765-8.

\section{Kjellman 1980 \{published data only\}}

Kjellman N, Lanner A. Hyposensitization in childhood hay fever. A comparison of refined and whole timothy extracts. Allergy 1980;35(4):323-34.

\section{Kleine-Tebbe 2005 \{published data only\}}

Kleine-Tebbe J, Herold D, Ribel M. Clinical safety of a grass pollen allergen tablet for specific immunotherapy. Journal of Allergy and Clinical Immunology 2005;115(2 (Suppl 1)):S266.

\section{Kleine-Tebbe 2006 \{published data only\}}

Kleine Tebbe J, Ribel M, Herold DA. Safety of a SQ-standardised grass allergen tablet for sublingual immunotherapy: a randomized, placebo-controlled trial. Allergy 2006;61(2):181-4.

\section{Kleinjans 2004 \{published data only\}}

Kleinjans H. Comparison between two SCIT Tree pollen regimens. Pre-seasonal use of a depot allergoid formulation versus full year use of a depot formulation over a 3 year period. XXIII Congress of the European Academy of Allergology and Clinical Immunology (EAACI). 2004.

\section{Klimek 1999a \{published data only\}}

Klimek L, Dormann D, Jarman ER, Cronwell O, Reichelmann H, Reske-Kunz AB. Short-term preseasonal birch pollen allergoid immunotherapy influences symptoms, specific nasal provocation and cytokine levels in nasal secretions, but not peripheral T-cell responses, in patients with allergic rhinitis. Clinical and Experimental Allergy 1999;29:1326-35.

\section{Klimek 1999b \{published data only\}}

Klimek L, Wolf H, Mewes T, Dormann D, Reske Kunz A, Schnitker J, Mann W. The effect of short-term immunotherapy with molecular standardized grass and rye allergens on eosinophil cationic protein and tryptase in nasal secretions. Journal of Allergy and Clinical Immunology 1999;103(1 (Pt 1)):47-53.

\section{Klimek 2005 \{published data only\}}

Klimek L, Mewes T, Wolf H, Hansen I, Schnitker J, Mann W. The effects of short-term immunotherapy using molecular standardized grass and rye allergens compared with symptomatic drug treatment on rhinoconjunctivitis symptoms, skin sensitivity, and specific nasal reactivity. Otolaryngology Head and Neck Surgery 2005;133(4):538-43.

\section{Kuhn 1983 \{published data only\}}

Kuhn W, Urbanek R, Forster J, Schreyer H, Wais U. Advantages of hyposensitization with a high dose of allergoid in pollen allergy [Vorteile einer Hyposensibilisierung mit hoher dosiertem Allergoid bei Pollenallergie]. Klinische Padiatrie 1983;195(6):411-4.

\section{Kuhn 1985 \{published data only\}}

Kuhn W, Urbanek R, Forster J, et al. Hyposensitization in pollen sensitive children: $A 3$ year prospective study [Hyposensibilisierung bei pollinosis: dreijahrige prospektive vergleichsuntersuchung bei kindern]. Allergologie 1985;8(3):103-9.

\section{Lavigne 2002 \{published data only\}}

Lavigne F, Desrosiers M, Blacquiere M, Dube N, Vaillancourt P, Tulic M, Eiden J, Hamid Q. Effect of AIC (AmbA 1 immunostimulatory oligonucleotide conjugate) on nasal allergen and inflammatory response to seasonal ragweed 
exposure [Abstract]. Journal of Allergy and Clinical Immunology 2002;109(1 (Suppl 1)):S205.

\section{Leiferman 1975 \{published data only\}}

Leiferman K, Yunginger J, Larson J, Gleich G. The effect of immune milk as a treatment for ragweed pollinosis. Annals of Allergy 1975;35(6):367-71.

\section{Levy 1971 \{published data only\}}

Levy D, Lichtenstein L, Goldstein E, Ishizaka K. Immunologic and cellular changes accompanying the therapy of pollen allergy. Journal of Clinical Investigations 1971;50(2):360-9.

\section{Li 1990 \{published data only\}}

Li J, Yunginger J, Reed C, Jaffe H, Nelson D, Gleich G. Lack of suppression of IgE production by recombinant interferon gamma: a controlled trial in patients with allergic rhinitis. Journal of Allergy and Clinical Immunology 1990;85(5):934-40.

\section{Lichtenstein 1968 \{published data only\}}

Lichtenstein L, Norman P, Winkenwerder W. Clinical and in vitro studies on the role of immunotherapy in ragweed hay fever. American Journal of Medicine 1968;44(4):514-24.

\section{Lichtenstein 1971 \{published data only\}}

Lichtenstein L, Norman P, Winkenwerder W. A single year of immunotherapy for ragweed hay fever. Immunologic and clinical studies. Annals of Internal Medicine 1971;75(5):663-71.

\section{Lichtenstein 1973 \{published data only\}}

Lichtenstein L, Ishizaka K, Norman P, Sobotka A, Hill B. IgE antibody measurements in ragweed hay fever. Relationship to clinical severity and the results of immunotherapy. Journal of Clinical Investigations 1973;52(2):472-82.

\section{Lindsay-Miller 1971 \{published data only\}}

Lindsay-Miller A. Pollen Tyrosine in the treatment of hay fever. Clinical Allergy 1971;1(3):351.

\section{Lombardi 2001 \{published data only\}}

Lombardi C, Gargioni S, Venturi S, Zoccali P, Canonica G, Passalacqua G. Controlled study of preseasonal immunotherapy with grass pollen extract in tablets: Effect on bronchial hyperreactivity. Journal of Investigational Allergology and Clinical Immunology 2001;11(1):41-5.

\section{Lowell 1965 \{published data only\}}

Lowell FC, Franklin W. A double-blind study of the effectiveness and specificity of injection therapy in ragweed hay fever. New England Journal of Medicine 1965;273:675-9.

\section{Machiels 1990 \{published data only\}}

Machiels J, Buche M, Somville M, Jacquemin M, Saint Remy J. Complexes of grass pollen allergens and specific antibodies reduce allergic symptoms and inhibit the seasonal increase of IgE antibody. Clinical and Experimental Allergy 1990;20(6):653-60.

\section{Malling 1999 \{published data only\}}

Malling HJ. Allergen specific immunotherapy for asthma. Ugeskr Laeger 2000;162 (4):477-9.
Manger 1984 \{published data only\}

Manger B, Hess B, Nüsslein H, Krapf F, Schreyer H, Maak G, Baenkler $\mathrm{H}$. Hyposensitization of hay fever patients with Tyrosin-adsorbed grass and rye pollen allergoid. Clinical and immunological parameters during different dosages with TA Tyrosin-Allergoid Gräserpollen [Hyposensibilisierung von Pollinosis-Patienten mit Tyrosin-adsorbiertem Gräserund Roggenpollenallergoid. Klinische und immunologische Untersuchungen bei verschiedenen Behandlungsschemata mit TA Tyrosin-Allergoid Gräserpollen]. Allergologie 1984;7(6):222-8.

\section{Martin Munoz 1996 \{published data only\}}

Martin Munoz M. Immunotherapy, clinical and bronchial response [Inmunoterapia, respuesta clinica y bronquial.]. Allergologia et Immunopathologia (Madrid) 1996;24(Suppl 1):68-79.

\section{Mastruzzo 2002 \{published data only\}}

Mastruzzo C, Crimi N, Gotti F, Sarva M, Mangano G, Paoline G, Vancheri C, Polposa R. Effect of specific immunotherpy on clinical and inflammatory markers in patients with seasonal allergic rhinitis [Abstract]. Journal of Allergy and Clinical Immunology 2002;109(1 (Suppl 1)):S201.

McAllen 1969 \{published data only\}

McAllen M. Hyposensitisation in grass pollen hay fever. Acta Allergol 1969;24:421-31.

\section{Mewes 1999 \{published data only\}}

Mewes T, Klimek L, Mann W, Bollessen M, Wolf H. Short term immune therapy with ALK7 reduces grass-pollen induces rhinoconjunctivitis symptoms and the specific nasal reactivity is more efficient than a symptomatic standard therapy [Kurzzeitimmuntherapie mit ALK7 reduziert die Graspolleninduzierten Rhinokonjunktivitis-Symptome und die spezifische nasale Reaktivitat effizienter als eine symptomatische Standardtherapie]. Allergologie 1999;22(9):581.

\section{Miller 1974 \{published data only\}}

Miller ACMA, Tees EC. A metabolizable adjuvant: clinical trial of grass pollen-tyrosine adsorbate. Clinical Allergy 1974;4:49-55.

Miller 1976 \{published data only\}

Miller A. A comparative trial of hyposensitization in 1973 in the treatment of hay fever using Pollinex and Alavac-P. Clinical Allergy 1976;6(6):551-6.

\section{Mitchell 1971 \{published data only\}}

Mitchell W, Davis N, Koenig W, Blank P. Emulsion therapy: a three-year study with ragweed pollinosis. Annals of Allergy 1971;29(11):564-72.

Moller 1989 \{published data only\}

Moller C. Effect of pollen immunotherapy on food hypersensitivity in children with birch pollinosis. Annals of Allergy 1989;62:343-5.

\section{Moller 2002 \{published data only\}}

Moller C, Dreborg S, Ferdousi HA, Halken S, Host A, Jacobsen L, et al. Pollen immunotherapy reduces the development of asthma in children with seasonal rhinoconjunctivitis 
(the PAT-study). Journal of Allergy and Clinical Immunology 2002;109:251-6.

\section{Mosbech 1987 \{published data only\}}

Mosbech H, Dreborg S, Madsen F, Ohlsson H, Stahl Skov P, Taudorf E, Weeke B. High dose grass pollen tablets used for hyposensitization in hay fever patients. A one-year double blind placebo-controlled study. Allergy 1987;42(6):451-5.

\section{Mosbech 1988 \{published data only\}}

Mosbech $\mathrm{H}$, Osterballe $\mathrm{O}$. Does the effect of immunotherapy last after termination of treatment? Follow-up study in patients with grass pollen rhinitis. Allergy 1988;43(7):523-9.

\section{Moss 1987 \{published data only\}}

Moss R, Hsu Y, Kwasnicki J, Sullivan M, Reid M. Isotypic and antigenic restriction of the blocking antibody response to ryegrass pollen: correlation of rye group I antigen-specific IgG1 with clinical response. Journal of Allergy and Clinical Immunology 1987;79(2):387-98.

\section{Moverare 1998 \{published data only\}}

Moverare R, Rak S, Elfman L. Allergen-specific increase in interleukin (IL)-4 and IL-5 secretion from peripheral blood mononuclear cells during birch-pollen immunotherapy. Allergy 1998;53(3):275-81.

\section{Moverare 2000 \{published data only\}}

Moverare R, Elfman L, Bjornsson E, Stalenheim G. Changes in cytokine production in vitro during the early phase of birchpollen immunotherapy. Scandinavian Journal of Immunology 2000;52(2):200-6.

\section{Muhlethaler 1990 \{published data only\}}

Muhlethaler K, Wuthrich B, Peeters A, Terki N, Girard J, Frank E. Hyposensitization in pollinosis. Results of a 3-year controlled study with 2 depot-allergoid grass pollen extracts: aluminum hydroxide-adsorbed allergoid and tyrosine-adsorbed allergoid [Zur Hyposensibilisierung der Pollinose. Ergebnisse einer kontrollierten Studie uber drei Jahre mit zwei DepotallergoidGraspollenextrakten: Aluminiumhydroxid-adsorbiertes Allergoid (AGD) und Tyrosin-adsorbiertes Allergoid (TA).]. Schweizerische Rundsdchau fur Medizinische Praxis 1990;79(14):430-6.

\section{Munoz Lejarazu 1993 \{published data only\}}

Munoz Lejarazu D, Bernaola G, Fernandez E, Audicana M, Ventas P, Martin S, Fernandez de Corres L. Seasonal versus perennial immunotherapy: evaluation after three years of treatment. Journal of Investigational Allergology and Clinical Immunology 1993;3(4):210-6.

\section{Naclerio 1997 \{published data only\}}

Naclerio RM, Proud D, Moylan B, Balcer S, Freidhoff L, Kagey SA, et al. A double-blind study of the discontinuation of ragweed immunotherapy. Journal of Allergy and Clinical Immunology 1997;100(3):293-300.

\section{Nakai 2002 \{published data only\}}

Nakai Y. Prophylactic immunotherapy for Japanese cedar pollen-sensitive individuals. Practica Otologica 2002;95(2):191-201.
Nakano 2002 \{published data only\}

Nakano A, Nakano K, Okawa T, Yamakoshi T, Terada N, Numata T, Konno A. The effect of Japanese cedar-specific immunotherapy on cytokine production in peripheral blood mononuclear cells. Acta Otolaryngologica 2002;122(1):54-60.

\section{Negro 1999 \{published data only\}}

Negro J, Wheeler A, Hernandez J, Youlten L, Pascual A, GarciaSelles $F$, et al. Comparison of the efficacy and safety of two preseasonal regimens of glutaraldehyde modified, tyrosineadsorbed parietaria pollen extract over a period of three years in monosensitive patients. Allergologia et Immunopathologia 1999;27:153-64.

\section{Nelson 1976 \{published data only\}}

Nelson H, Brown G, O'Barr T, Branch L, Spaulding H, Black J. Clinical and immunological studies of timothy antigen $\mathrm{D}$ immunotherapy. Journal of Allergy and Clinical Immunology 1976;57(5):463-72.

\section{Niederberger 2004 \{published data only\}}

Niederberger V, Horak F, Vrtala S, Spitzauer S, Krauth M, Valent $P$, et al. Vaccination with genetically engineered allergens prevents progression of allergic disease. Proceedings of the National Academy of Sciences of the United States of America 2004;101(2):14677-82.

\section{Nielsen 1996 \{published data only\}}

Nielsen L, Johnsen C, Mosbech H, Poulsen L, Malling H. Antihistamine premedication in specific cluster immunotherapy: a double-blind, placebo-controlled study. Journal of Allergy and Clinical Immunology 1996;97(6):1207-13.

Nolte 1999 \{published data only\}

Nolte $\mathrm{H}$. Allergen extracts, dosing, efficacy and safety of immunotherapy. International Review of Allergology and Clinical Immunology 1999;5 (3):184-8.

\section{Norman 1968 \{published data only\}}

Norman P, Winkenwerder W, Lichtenstein L. Immunotherapy of hay fever with ragweed antigen $\mathrm{E}$ : comparisons with whole pollen extract and placebos. Journal of Allergy 1968;42(2):93-108.

\section{Norman 1969 \{published data only\}}

Norman P. A rational approach to desensitization. Journal of Allergy 1969;44(3):129-45.

\section{Norman 1971 \{published data only\}}

Norman P, Winkenwerder W, Lichtenstein L. Maintenance immunotherapy in ragweed hay fever. Booster injections at six week intervals. Journal of Allergy 1971;47(5):273-82.

\section{Norman 1972 \{published data only\}}

Norman PS, Winkenwerder WL, Lichtenstein LM. Trials of alumprecipitated pollen extracts in the treatment of hay fever. Journal of Allergy and Clinical Immunology 1972;50 (1):31-44.

\section{Norman 1981 \{published data only\}}

Norman P, Lichtenstein L, Marsh D. Studies on allergoids from naturally occurring allergens. IV. Efficacy and safety of long- 
term allergoid treatment of ragweed hay fever. The Journal of Allergy and Clinical Immunology 1981;68(6):460-70.

Norman 1984 \{published data only\}

Norman P, King T, Alexander JJ, et al. Immunologic responses to conjugates of antigen $E$ in patients with ragweed hay fever. Journal of Allergy and Clinical Immunology 1984;73(6):782-9.

\section{Norman 1990b \{published data only\}}

Norman P, Creticos P, Marsh D. Frequency of booster injections of allergoids. Journal of Allergy and Clinical Immunology 1990;85(1 (Pt 1)):88-94.

Nouri 2005 \{published data only\}

Nouri A, Pilette C, Jacobson M, Watanabe H, Durham S. IL-9 and c-Kit+ mast cells in allergic rhinitis during seasonal allergen exposure: effect of immunotherapy. Journal of Allergy and Clinical Immunology 2005;116(1):73-9.

Nouri-Aria 2004a \{published data only\}

Nouri-Aria K, Pilette C, Jacobson M, Wilson D, Durham S. Grass pollen immunotherapy (IT) decreases IL-9 mRNA expressing cells in the nasal mucosa during the pollen season. [Abstract]. Journal of Allergy and Clinical Immunology 2004;113(Suppl 2):S106.

\section{Nouri-Aria 2004b \{published data only\}}

Nouri-Aria K, Wachholz P, Francis J, Jacobson M, Walker S, Wilcock $\mathrm{L}$, et al. Grass pollen immunotherapy induces mucosal and peripheral IL-10 responses and blocking IgG activity. Journal of Immunology 2004;172(5):3252-9.

\section{Nowak-Wegrzyn 2004 \{published data only\}}

Nowak-Wegrzyn A, Mofidi S, Ma S, Bardina L, Beyer K. Birch and ragweed pollen immunotherapy in the treatment of pollenfood allergy syndrome [Abstract]. Journal of Allergy and Clinical Immunology 2004;113(Suppl 2):S146.

\section{Ohashi 1997 \{published data only\}}

Ohashi Y, Nakai Y, Kakinoki Y, Ohno Y, Okamoto H, Sakamoto H, Kato A, Tanaka A. The effect of immunotherapy on the serum levels of eosinophil cationic protein in seasonal allergic rhinitis.. Clinical Otolaryngology and Allied Sciences 1997;22(2):100-5.

\section{Olsen 1995 \{published data only\}}

Olsen O, Frolund L, Heinig J, Jacobsen L, Svendsen U. A double-blind, randomized study investigating the efficacy and specificity of immunotherapy with Artemisia vulgaris or Phleum pratense/betula verrucosa. Allergologia et Immunopathologia (Madrid) 1995;23(2):73-8.

\section{Osterballe 1980 \{published data only\}}

Osterballe 0 . Immunotherapy in hay fever with two major allergens 19,25 and partially purified extract of timothy grass pollen. Allergy 1980;35:473-89.

\section{Osterballe 1982 \{published data only\}}

Osterballe $\mathrm{O}$. Immunotherapy with grass pollen major allergens. Clinical results from a prospective 3-year double blind study. Allergy 1982;37:379-88.

\section{Osterballe 1982a \{published data only\}}

Osterballe 0 . Nasal and skin sensitivity during immunotherapy with two major allergens 19, 25 and partially purified extract of timothy grass pollen. Allergy 1982;37(3):169-77.

Osterballe 1982b \{published data only\}

Osterballe O, Egeskjold E, Johansen A, Skov P. Anti-IgG antibodies during immunotherapy with purified grass pollen extracts. Allergy 1982;37(3):209-16.

Osterballe 1982c \{published data only\}

Osterballe O, Lowenstein H, Norn S, Prahl P, Skov P, Skov P, Weeke B. Immunotherapy with grass pollen major allergens. Immunological results from a prospective 3-year double blind study. Allergy 1982;37(7):491-501.

Osterballe 1982d \{published data only\}

Osterballe O, Lowenstein H, Prahl P, Skov P, Weeke B. Immunotherapy in hay fever with timothy major allergens. Allergy 1982;37(Suppl 1):8-9.

\section{Osterballe 1982e \{published data only\}} Osterballe 0 . Side effects during immunotherapy with purified grass pollen extracts. Allergy 1982;37(8):553-62.

Osterballe 1983 \{published data only\}

Osterballe O, Ipsen H, Weeke B, Lowenstein H. Specific IgE response toward allergenic molecules during perennial hyposensitization: a three-year prospective double-blind study. Journal of Allergy and Clinical Immunology 1983;71(1 (Pt 1)):40-6

Parr 1976 \{published data only\}

Parr E. Hay fever treated with ACTH gel. Clinical Allergy 1976;6(5):479-86.

\section{Pastorello 1987 \{published data only\}}

Pastorello EA, Incorvaia C, Gerosa A, Vassellatti D, Italia M, Pravettoni V. Allergen specific IgG subclass antibody response in hyposensitization with Dermatophagoides pteronyssinus extract. New England and Regional Allergy Proceedings 1987;8(6):417-21.

\section{Pastorello 1988 \{published data only\}}

Pastorello E, Pravettoni V, Qualizza R, Codecasa L, Incorvaia C. A double blind placebo controlled trial of specific immunotherapy with aluminium hydroxide adsorbed allergoid in grass pollen induced rhinitis. Allergy 1988;43(Suppl 7):48.

\section{Pence 1976 \{published data only\}}

Pence HL, Mitchell DQ, Greely RL, Updegraff BR, Selfridge HA. Immunotherapy for mountain cedar pollinosis. Journal of Allergy and Clinical Immunology 1976;58:39-50.

Peng 1992 \{published data only\}

Peng Z, Naclerio R, Norman P, Adkinson NJ. Quantitative IgEand IgG-subclass responses during and after long-term ragweed immunotherapy. Journal of Allergy and Clinical Immunology 1992;89(2):519-29. 
Pereira 2003 \{published data only\}

Pereira S, Clark T, Darby Y, Salib R, Salagean M, Hewitt L, Powell J, Howarth P, Scadding G. Effects of anti-eotaxin monoclonal antibody CAT-213 on allergen-induced rhinitis. Journal of Allergy and Clinical Immunology 2003;111(2 (Pt 2)):S268.

\section{Petersen 1988 \{published data only\}}

Petersen BN, Janniche H, Munch EP, Wihl JA, Bowadt H, Ipsen $\mathrm{H}$, Lowenstein $\mathrm{H}$. Immunotherapy with partially purified and standardized tree pollen extracts. Allergy 1988;43:353-62.

Pilette 2003 \{published data only\}

Pilette C, Nouri-Aria K, Jacobson M, Durham S. Seasonal increases in interleukin- 9 expression and in mast cell infiltration of the nasal mucosa in allergic rhinitis are inhibited by grass pollen immunotherapy. XXII Congress of the European Academy of Allergology and Clinical Immunology (EAACI). 2003.

\section{Polosa 2003 \{published data only\}}

Polosa R, Ligotti F, Mangano G, Mastruzzo C, Pistorio M, Crimi N. Monitoring of seasonal variability in bronchial hyperresponsiveness and sputum cell counts in non-asthmatic subjects with rhinitis and effect of specific immunotherapy. Clinical and Experimental Allergy 2003;33(7):873-81.

\section{Pronk-Admiraal 2001 \{published data only\}}

Pronk-Admiraal C, Schilte P, Bartels P. Effect of immunotherapy on eosinophil activation in pollen sensitive children. Clinical Laboratory 2001;47(5-6):231-8.

\section{Radcliffe 1996 \{published data only\}}

Radcliffe MJ, Lampe FC, Brostoff J. Allergen-specific low-dose immunotherapy in perennial allergic rhinitis: A double-blind placebo-controlled crossoever study. Journal of Investigational Allergology and Clinical Immunology 1996;6:242-7.

\section{Radcliffe 2003 \{published data only\}}

Radcliffe M, Lewith G, Turner R, Prescott P, Church M, Holgate S. Enzyme potentiated desensitisation in the treatment of seasonal allergic rhinitis: double blind randomised controlled study. BMJ 2003;327(7409):251-4.

\section{Rajakulasingam 1997 \{published data only\}}

Rajakulasingam K, Durham S, O'Brien F, Humbert M, Barata L, Reece L, Kay A, Grant J. Enhanced expression of high-affinity IgE receptor (Fc epsilon RI) alpha chain in human allergen-induced rhinitis with co-localization to mast cells, macrophages, eosinophils, and dendritic cells. Journal of Allergy and Clinical Immunology 1997;100(1):78-86.

\section{Rak 1988 \{published data only\}}

Rak S, Lowhagen O, Venge P. The effect of immunotherapy on bronchial hyperresponsiveness and eosinophil cationic protein in pollen-allergic patients. Journal of Allergy and Clinical Immunology 1988;82:470-80.

\section{Rak 1990 \{published data only\}}

Rak S, Hakanson L, Venge P. Immunotherapy abrogates the generation of eosinophil and neutrophil chemotactic activity during pollen season. Journal of Allergy and Clinical Immunology 1990;86(5):706-13.

Rak 2001 \{published data only\}

Rak S, Heinrich C, Jacobsen L, Scheynius A, Venge P. A doubleblinded, comparative study of the effects of short preseason specific immunotherapy and topical steroids in patients with allergic rhinoconjunctivitis and asthma. Journal of Allergy and Clinical Immunology 2001;108:921-8.

Rasp 1999 \{published data only\}

Rasp G, Klimek L. Short-term immunotherapy-a survey of current studies. Wiener Medizinische Wochenschrift 1999;149(14-15):403-9.

\section{Ricca 1997 \{published data only\}}

Ricca V, Ciprandi G, Pesce G, Riccio A, Varese P, Pecora S, Canonica G. Preseasonal specific immunotherapy with modified Phleum pratense allergenic extracts: tolerability and effects. Allergologia et Immunopathologia (Madrid) 1997;25(4):167-75.

Roberts 2006 \{published data only\}

Roberts G, Hurley C, Turcanu V, Lack G. Grass pollen immunotherapy as an effective therapy for childhood seasonal allergic asthma. Journal of Allergy and Clinical Immunology 2006;117:263-8.

\section{Rogala 2004 \{published data only\}}

Rogala B, Jarzab J, Rymarczyk B, Tluczykont B. Allergen specific-IgG4 in circulating immune complexes in patients with inhalant allergy undergoing specific immunotherapy [Wplyw swoistej immunoterapii alergii wziewnej na stezenie IgG4 w krazacych kompleksach immunologicznych]. Wiadomosci lekarskie 2004;57(3-4):123-30.

Rover 2002 \{published data only\}

Rover A, Reimann S, Zuberbier T, Worm M. Immunophenotypic characterization of peripheral B cells: During shortterm immunotherapy with tree pollen allergoid and the immunoadjuvant monophosphoryl lipid A. Journal of Investigational Allergology and Clinical Immunology 2002;12(4):227-34

\section{Rozniecka 1995a \{published data only\}}

Rozniecka M, Kowalski M, Grzegorczyk J, Wojciechowska B, Sliwinska KM, Rozniecki J. Characteristics of hay fever during pollen season with regard to the influence of specific immunotherapy. I. Clinical course and biochemical changes in nasal lavage] [Przebieg pylkowicy w sezonie pylenia z uwzglednieniem wplywu swoistej immunoterapii. Czesc I: Przebieg kliniczny i zmiany biochemiczne w wydzielinie z nosa]. Pneumonologia i Alergologia Polska 1995;63(3-4):135-43.

\section{Rozniecka 1995b \{published data only\}}

Rozniecka M, Kowalski M, Grzegorczyk J, Wojciechowska B, Sliwinska-Kowalska M, Rozniecki J. The characteristics of pollinosis during the pollen season and the influence of specific immunotherapy. Part II: Cytologic changes and chemotactic activity in nasal lavage [Przebieg pylkowicy w sezonie pylenia z uwzglednieniem wplywu immunoterapii swoistej Czesc II: Zmiany cytologiczne i aktywnosc chemotaktyczna w 
wydzielinie z nosa]. Pneumonologia i Alergologia Polska 1995;63(3-4):144-52.

\section{Ruiz 2001 \{published data only\}}

Ruiz A, Casanovas M, Gomez MJ, Cimarra M, MartinezCocera C, Fernandez-Caldas E, Leti CBF. Safety and efficacy of immunotherapy with a standardized depigmented and glutaraldehyde-polyerized extract of phleum pratense pollen. Journal of Allergy and Clinical Immunology 2001;107(2 (Pt 2)):S260.

\section{Sandstrom 2001 \{published data only\}}

Sandstrom T, Adelroth E, Rak S, Haahtela T, Aasand G, Rosenhall $\mathrm{L}$, et al. Xolair is effective in the treatment of seasonal birch pollen allergic rhinitis. Annals of Allergy, Asthma and Immunology 2001;86:83.

\section{Scordamaglia 1992 \{published data only\}}

Scordamaglia A, Passalacqua G, Pisati P, Moscato G, Bertoletti R, Ruffoni S, Canonica G. A multi-allergen ELISA screening method. Comparison with Pharmacia CAP system and Phazet skin prick test. Allergologia et Immunopathologia (Madrid) 1992;20(5):179-83.

\section{Simon 1990a \{published data only\}}

Simon H, Metzner G, Keil E, Forner K, Vogt W, Jager L. PhaseI study of diacetyl-splenopentin (BCH 069). Allergie und Immunologie 1990;36(4):245-51.

\section{Simon 1990b \{published data only\}}

Simon H, Metzner G, Vogt W, Piesch C, Forner K, Schlenvoigt G, Storz H, Haroske D, Jager L. Clinical, biochemical and immunological effectiveness of diacetyl-splenopentin (BCH 069) in hay fever. Allergologia et Immunopathologia (Madrid) 1990;18(3):155-60.

\section{Simons 2003 \{published data only\}}

Simons F, Shikishima Y, van Nest G, Eiden J, HayGlass K. Allergen-selective redirection of immunoregulatory responses in ragweed-allergic humans using dynavax Amb a 1 immunostimulatory oligodeoxyribonucleotide conjugate (AIC). Journal of Allergy and Clinical Immunology 2003;111 (2 (Pt 2)):S267.

\section{Sin 1996 \{published data only\}}

Sin B, Misirhgil Z, Aybay C, Gurbuz L, Imir T. Effect of allergen specific immunotherapy on natural killer cell activitiy, IgE, IFN$\mathrm{g}$ levels and clinical response in patients with allergic rhinitis and asthma. Journal of Investigational Allergology and Clinical Immunology 1996;6:341-7.

\section{Skoda-Turk 1980 \{published data only\}}

Skoda-Turk R, Horak F, Jager S. A modified therapy of hayfever with a depot-preparation (author's transl) [Modifizierte Therapie mit einem Depotpraparat bei Graserpollenallergie.]. Wiener Klinische Wochenschrift. Supplementum 1980;117:24-6.

\section{Sobel 1966 \{published data only\}}

Sobel G. Treatment of grass pollenosis with various preparations: eleven-year study. Annals of Allergy 1966;24(9):459-68.

\section{Soyogul 2005 \{published data only\}}

Soyogul G, Bueyuekoeztuerk S, Palanduez S, Rayaman E, Colakoglu B, Cevikbas A. The effects of allergen-specific immunotherapy on polymorphonuclear leukocyte functions in patients with seasonal allergic rhinitis. International Immunopharmacology 2005;5(4):661-6.

\section{Spiegelman 1967 \{published data only\}}

Spiegelman J, Friedman H, Tuft L. Immunologic responses of pollinosis patients treated with alum-precipitated pyridine ragweed extract. Annals of Allergy 1967;25(5):262-74.

Stuck 2001 \{published data only\}

Stuck B, Schneider-Gene S, Klimek L, Hoermann K. Birch pollen allergoid plus MPL in short-term immunotherapy. Otolaryngology - Head and Neck Surgery 2001;125(2):P199-200.

Stuck 2004 \{published data only\}

Stuck B, Schneider G, Schaefer D, Klimek L, Hoermann K. Shortterm preseasonal immunotherapy with birch pollen allergoid plus monophosphoryllipid A (MPL) - Influence on cytokine production of peripheral T cells in patients with allergic rhinitis. Allergy and Clinical Immunology International 2004;16(2):60-4.

\section{Sykora 2004 \{published data only\}}

Sykora T, Tamele L, Zemanova M, Petras M. Efficacy and safety of specific allergen immunotherapy with standardized depod allergen $\mathrm{H}$-Al depot (pollens) [Ucinnost a bezpecnost alergenove imunoterapie se standardizovanymi depotnimi alergeny h-ai depot (pollens)]. Alergie 2004;6(3):170-8.

\section{Symington 1977 \{published data only\}}

Symington I, O'Neill D, Kerr J. Comparision of a glutaraldehydemodified pollen--tyrosine adsorbate with an alum-precipitated pollen vaccine in the treatment of hay fever.. Clinical Allergy 1977;7(2):189-94.

\section{Taudorf 1983 \{published data only\}}

Taudorf E, Weeke B. Orally administered grass pollen. Allergy 1983;38(8):561-4.

\section{Te Pas 2004 \{published data only\}}

Te Pas E, Hoyte E, McIntire J, Umetsu D. Clinical efficacy of microencapsulated timothy grass pollen extract in grassallergic individuals. Annals of Allergy, Asthma, and Immunology 2004;92(1):25-31.

\section{Troise 2000 \{published data only\}}

Troise C, Bignardi D, Modena P, Pissacroia C, Di Berardino F. Preventive symptomatic immunotherapy versus placebo in seasonal rhinitis due to grasses in children and to Parietaria in adult patients. Allergie et Immunologie 2000;32(6):246-9.

\section{Tulic 2004 \{published data only\}}

Tulic M, Fiset P, Christodoulopoulos $P$, Vaillancourt $P$, Desrosiers M, Lavigne F, Eiden J, Hamid Q. Amb a 1immunostimulatory oligodeoxynucleotide conjugate immunotherapy decreases the nasal inflammatory response. Journal of Allergy and Clinical Immunology 2004;113(2):235-41. 
Turkeltaub 1990 \{published data only\}

Turkeltaub P, Campbell G, Mosimann J. Comparative safety and efficacy of short ragweed extracts differing in potency and composition in the treatment of fall hay fever. Use of allergenically bioequivalent doses by parallel line bioassay to evaluate comparative safety and efficacy. Allergy 1990;45(7):528-46.

\section{Vaishnav 2005 \{published data only\}}

Vaishnav A, Whaley S, Hamilton R, Levitt D, Creticos P. Evaluation of safety and clinical efficacy of higher dose immunotherapy with AIC (immunostimulatory DNA conjugated with $A m b$ a 1) in patients with ragweed-induced seasonal allergic rhinitis (SAR) [Abstract]. Journal of Allergy and Clinical Immunology 2005;115(2 (Suppl 1)):S65.

\section{Valovirta 1999 \{published data only\}}

Valovirta E. PAT-the Preventive Allergy Treatment Study design and preliminary results. Wiener Medizinische Wochenschrift 1999;149(14-5):442-3.

\section{van Adelsberg 2003 \{published data only\}}

van Adelsberg J, Philip G, Pedinoff A, Meltzer E, Ratner P, Menten J, Reiss T. Montelukast improves symptoms of seasonal allergic rhinitis over a 4-week treatment period. Allergy 2003;58(12):1268-76.

\section{Van Metre 1980a \{published data only\}}

Van Metre TE, Adkinson NF, Lichtenstein LM, Mardiney MR, Norman PS, Rosenberg GL, Sobotka AK, Valentine MD. A controlled study of the effectiveness of the Rinkel method of immunotherapy for ragweed pollen hay fever. Journal of Allergy and Clinical Immunology 1980;65:288-97.

\section{Van Metre 1980b \{published data only\}}

Van Metre TE, Adkinson NF, Amodio FJ, Lichtenstein LM, Mardiney MR, Norman PS, et al. A comparative study of the effectiveness of the Rinkel method and the current standard method of immunotherapy for ragweed pollen hay fever. Journal of Allergy and Clinical Immunology 1980;66:500-13.

van Metre 1982 \{published data only\}

van Metre TJ, Adkinson NJ, Amodio F, Kagey-Sobotka A, Lichtenstein L, Mardiney MJ, et al. A comparison of immunotherapy schedules for injection treatment of ragweed pollen hay fever. Journal of Allergy and Clinical Immunology 1982;69(2):181-93.

\section{Vanselow 1966 \{published data only\}}

Vanselow N, Kelly J, Meyers M, Johnson A. The effect of 6mercaptopurine on antibody production in atopic individuals. Journal of Allergy 1966;37:145-57.

\section{Varney 1992 \{published data only\}}

Varney V, Jacobson M, Sudderick R, Robinson D, Irani A, Schwartz L, Mackay I, Kay A, Durham S. Immunohistology of the nasal mucosa following allergen-induced rhinitis. Identification of activated T lymphocytes, eosinophils, and neutrophils. American Review of Respiratory Disease 1992;146(1):170-6.

\section{Varney 1993 \{published data only\}}

Varney VA, Hamid QA, Gaga M, Sun Ying M, Jacobson M, Frew AJ, Kay AB, Durham SR. Influence of grass pollen immunotherapy on cellular infiltration and cytokine mRNA expression during allergen-induced late-phase cutaneous responses. Journal of Clinical Investigations 1993;92:644-51.

\section{Verstraeten 1987 \{published data only\}}

Verstraeten J, Verstraeten A. Clinical evaluation of hyposensitization in allergic rhinitis: comparison of the results obtained with three different extracts. Material from a 3-year study. Annals of Allergy 1987;58(6):416-20.

\section{Vittorio 1996 \{published data only\}}

Vittorio R, Giorgio C, Giampaola G, Annamaria R, Paola V, Silvia P, Walter C. Preseasonal specific immunotherapy with modified phleum pratense allergenic extracts: tolerability and effects. Allergologia et Immunopathologia 1996;24(6):255-62.

\section{Wachholz 2002 \{published data only\}}

Wachholz P, Nouri-Aria K, Wilson D, Walker S, Verhoef A, Till S, Durham S. Grass pollen immunotherapy for hayfever is associated with increases in local nasal but not peripheral Th1:Th2 cytokine ratios. Immunology 2002;105(1):56-62.

\section{Wahn 2003 \{published data only\}}

Wahn U, Meltzer E, Finn AJ, Kowalski M, Decosta P, Hedlin G, et al. Fexofenadine is efficacious and safe in children (aged 6-11 years) with seasonal allergic rhinitis. [ Erratum appears in J Allergy Clin Immunol. $2003 \mathrm{Jul} ; 112(1): 71]$. Journal of Allergy and Clinical Immunology 2003;111(4):763-9.

\section{Walker 1995 \{published data only\}}

Walker SM, Varney VA, Gaga M, Jacobson MR, Durham SR. Grass pollen immunotherapy: efficacy and safety during 4-year followup study. Allergy 1995;50:405-13.

\section{Walker 2003 \{published data only\}}

Walker S, Jacobson M, Durham S. Grass pollen immunotherapy for two years has sustained effects during two years doubleblind placebo-controlled withdrawal of treatment. Journal of Allergy and Clinical Immunology 2003;111(2 (Pt 2)):S267.

\section{Watanabe 2003 \{published data only\}}

Watanabe H, Nouri-Aria K, Jacobson M, Wilson D, Durham S. Successful grass pollen immunotherapy inhibits eosinophil accumulation in the nasal mucosa: role of adhesion molecules and apoptosis [Abstract]. Allergy and Clinical Immunology International 2003;15(Suppl 1):Abstract No.0-14-2.

\section{Weyer 1981a \{published data only\}}

Weyer A, Donat N, L'Heritier C, Juilliard F, Pauli G, Soufflet B, David B. Grass pollen hyposensitization versus placebo therapy. I. Clinical effectiveness and methodological aspects of a preseasonal course of desensitization with a four-grass pollen extract. Allergy 1981;36(5):309-17.

\section{Weyer 1981b \{published data only\}}

Weyer A, Doinel C, Debbia M, L'Heritier C, Rivat L, Le Mao J, Hirth C, David B. Grass pollen hyposensitization versus placebo 
therapy. II. Immunotherapy-induced changes in serum IgE and IgG levels. Allergy 1981;36(5):319-28.

Weyer 1990 \{published data only\}

Weyer A, Guinnepain MT, Sutra JP, Borgnon A, Herpin-Richard N, Ickoviv MR, et al. Seasonal increase of spontaneous histamine release in washed leucocytes from rhinitis patients sensitive to grass pollen. Clinical and Experimental Immunology 1990;79:385-91.

\section{Wihl 1988 \{published data only\}}

Wihl JA, Ipsen H, Petersen BN, Munch EP, Janniche $\mathrm{H}$, Lowenstein $\mathrm{H}$. Immunotherapy with partially purified and standardized tree pollen extracts. Allergy 1988;43:363-9.

\section{Wilcock 2005 \{published data only\}}

Wilcock L, Wachholz P, Na D, Klunker S, Francis J, Larsen J, Durham S. Time-course of Serum IgG4 levels and IgG inhibitory activity following withdrawal of grass pollen immunotherapy (IT). Journal of Allergy and Clinical Immunology 2005;115(2 (Suppl 1)):S265.

\section{Williams 2001 \{published data only\}}

Williams A, McCarthy K, Howarth P, Stern M, Eccles R, Rajakulasingam $\mathrm{K}$. A study to determine the efficacy of a nasally administered rye grass peptide, Ptl-0901, in the treatment of severe seasonal hayfever. Journal of Allergy and Clinical Immunology 2001;107(2 (Pt 2)):S256.

\section{Williams 2002 \{published data only\}}

Williams AM, Frank E, Meyer $\mathrm{H}$, Cromwell O, Rajakulasingham RK. Effectiveness of preseasonal allergoid immunotherapy in patients with grass pollen allergy [Abstract]. Allergy 2002;57(s73):51.

\section{Wilson 2001a \{published data only\}}

Wilson D, Irani A, Walker S, Jacobson M, Mackay I, Schwartz L, Durham S. Grass pollen immunotherapy inhibits seasonal increases in basophils and eosinophils in the nasal epithelium. Clinical and Experimental Allergy 2001;31(11):1705-13.

\section{Wilson 2001b \{published data only\}}

Wilson D, Nouri-Aria K, Walker S, Pajno G, O'Brien F, Jacobson M, Mackay I, Durham S. Grass pollen immunotherapy: symptomatic improvement correlates with reductions in eosinophils and IL-5 mRNA expression in the nasal mucosa during the pollen season. Journal of Allergy and Clinical Immunology 2001;107(6):971-6.

\section{Winther 2000a \{published data only\}}

Winther L, Malling H, Moseholm L, Mosbech H. Allergen-specific immunotherapy in birch- and grass-pollen-allergic rhinitis. I. Efficacy estimated by a model reducing the bias of annual differences in pollen counts. Allergy 2000;55(9):818-26.

\section{Winther 2000b \{published data only\}}

Winther L, Malling $\mathrm{H}$, Mosbech $\mathrm{H}$. Allergen-specific immunotherapy in birch- and grass-pollen-allergic rhinitis. II. Side-effects. Allergy 2000;55(9):827-35.

\section{Wuthrich 1968 \{published data only\}}

Wuthrich B, Storck H. Desensitization results in pollen allergic patients with allpyral and aqueous extracts [Desensibilisierungresulate bei Pollenallergikern mit Allpyral und mit wasserigen Extrakten]. Schweizerische Medizinische Wochenschrift. Journal Suisse de Medecine 1968;98(17):653-8.

\section{Wuthrich 1977 \{published data only\}}

Wuthrich B. Immunotherapy of pollinosis: results of a 2-year study with a new allergen preparation (novo-helisen depot) (author's transl) [Zur spezifischen Hyposensibilisierung der Pollinosis. Ergebnisse einer zweijahrigen Studie mit einem neuen Allergen-Praparat (Novo-Helisen Depot)]. Schweizerische Rundsdchau fur Medizinische Praxis 1977;66(9):260-6.

\section{Wuthrich 1980 \{published data only\}}

Wuthrich B, Hafner G. Pollinosis. II. Specific hyposensitization: indications and results of treatment. A study with the allergen preparation Stallergenes-Depot in the pollen season of 1976, 1977 and 1978 [Pollinosis. II. Spezifische Hyposensibilisierung: Indikation und Behandlungsergebnisse Eine Studie mit dem Allergen-Praparat Stallergenes-Depot in der Pollensaison 1976, 1977 und 1978]. Schweizerische Medizinische Wochenschrift. Journal Suisse de Medecine 1980;110(8):281-90.

\section{Yariktas 2002 \{published data only\}}

Yariktas M, Unlu M, Doner F, Sahin U. Comparison of Leukotriene Receptor Antagonist and Antihistamine Therapy in Seasonal Allergic Rhinitis [Mevsimsel Allerjik Rinitte Lökotrien Reseptör Antagonisti ile Antihistaminik Tedavisinin Karsilastirilmasi]. Turkish Archives of Otolaryngology 2002;40(4):252-6.

\section{References to studies awaiting assessment}

Frank 2001 \{published data only\}

Frank E, Williams A, Cromwell O, Atkinson P, Rajakulasingam K. Effectiveness of a pre-seasonal allergoid immunotherapy in patients with seasonal allergic rhinitis due to grass pollen. Journal of Allergy and Clinical Immunology 2001;107(2 (Pt 2)):S260.

\section{Szymanski 1996 \{published data only\}}

Szymanski W, Rogalewska A, Zlotnik I, Obrzut D, ChyrekBorowska S. The clinical evaluation of Polish allergen extracts $C$ atalet $C$ and Catalet $D$ in patients with pollinosis. Pneumonologia i Alergologia Polska 1996;64(Suppl 2):25-31.

\section{References to ongoing studies}

\section{Rajakulasingam 2006 \{published data only\}}

Rajakulasingam, K. Study for evaluation of safety and efficacy of a pre-seasonal immunotherapy with an allergoid preparation of an extract of a 6 grass pollen mixture in pts with a clinically relevant grass pollen sensitivity. National Research Register 2006. 


\section{Additional references}

\section{Aaronson 2004}

Aaronson DW, Gandhi TK. Incorrect allergy injections: Allergists' experiences and recommendations for prevention. Journal of Allergy and Clinical Immunology 2004;113:1117-21.

\section{Aberg 1989}

Aberg N. Asthma and allergic rhinitis in Swedish conscripts. Clinical Experimental Allergy 1989;19:59-63.

\section{Bauchau 2004}

Bauchau V, Durham SR. Prevalence and rate of diagnosis of allergic rhinitis in Europe. European Respiratory Journal 2004;24:758-64.

\section{Bernstein 2004}

Bernstein DI, Wanner M, Borish L, Liss GM and the Immunotherapy Committee of the American Academy of Allergy, Asthma, Immunology. Twelve-year survey of fatal reactions to allergen injections and skin testing: 1990-2001. Journal of Allergy and Clinical Immunology 2004;113:1129-36.

\section{Bousquet 2001}

Bousquet J, Van Cauwenberge P, Khaltaev N. ARIA Workshop Group. World Health Organization. Allergic Rhinitis and its impact on Asthma. Journal of Allergy and Clinical Immunology 2001;108 (Suppl 5):S147-S334.

\section{CSACI 1995}

Canadian Society of Allergy and Clinical Immunology. Guidelines for the use of allergen immunotherapy. Canadian Medical Association Journal 152;1995:1413-9.

\section{CSM 1986}

Committee of the Safety of Medicine. CSM update: desensitizing vaccines. British Medical Journal 1986;293:948.

\section{CSM 1994}

Committee of the Safety of Medicine. Desensitising vaccines: New advice. Current Problems in Pharmacovigilance 1994;20:5.

\section{Dreborg 1992}

Dreborg S, Einarsson R. The major allergen content of allergen extracts reflects their biological activity. Allergy 1992;47:418-23.

\section{Durham 1998}

Durham S. ABC of allergies. Summer hay fever. British Medical Journal 1998;316:843-5.

\section{Durham 1999b}

Durham S, Walker S, Varga E-M, Jacobson M, O'Brien F, Noble $W$, et al. Long-term clinical efficacy of grasspollen immunotherapy. New England Journal of Medicine 1999;341(7):468-75.

\section{Fleming 1987}

Fleming DM, Crombie DL. Prevalence of asthma and hay fever in England and Wales. British Medical Journal 1987;294:279-83.

\section{Frew 1993}

Frew AJ. Injection immunotherapy. British Medical Journal 1993;307:919-23.

Gupta 2004

Gupta R, Sheikh A, Strachan DP, Anderson HR. Burden of allergic disease in the UK: secondary analyses of national databases. Clinical and Experimental Allergy 2004;34:520-6.

\section{ISAAC 1998}

The International Study of Asthma and Allergies in Childhood (ISAAC) Steering Committee. Worldwide variation in prevalence of symptoms of asthma, allergic rhinoconjunctivitis, and atopic eczema: ISAAC. Lancet 1998;351:1225-32.

\section{Jarvis 1998}

Jarvis D, Burney P. ABC of allergies. The epidemiology of allergic disease. British Medical Journal 1998;316:607-10.

\section{Junker 1996}

Junker C, Egger M, Schneider M, Zellweger T, Antes G. The CONSORT statement. JAMA 1996;276(8):637-9.

\section{Lund 1994}

Lund VJ, Aaronsen D, Bousquet J, Dahl R, Davies RJ, Durham SR, et al. International consensus report on the diagnosis and management of rhinitis. Allergy 1994;49(Suppl 19):1-34.

\section{Malling 1993}

Malling HJ, Weeke B. Immunotherapy. Position paper of the European Academy of Allergology and Clinical Immunology. Allergy 1993;48(14):9-35.

\section{Malling 2001}

Malling HJ. Allergen-specific immunotherapy in allergic rhinitis. Current Opinion in Allergy and Clinical Immunology 2001;1:43-6.

\section{Mygind 1996}

Mygind N, Dahl R. Epidemiology of allergic rhinitis. Pediatric Allergy and Immunology 1996;7 (9 Suppl):57-62.

\section{Ninan 1992}

Ninan TK, Russell G. Respiratory symptoms and atopy in Aberdeen schoolchildren evidence from two surveys 25 years apart. British Medical Journal 1992;304:873-5.

\section{Norman 1990}

Norman PS, Van Metre TE. The safety of allergenic immunotherapy. Journal of Allergy Clinical Immunology 1990;86:522-5.

\section{Reid 1993}

Reid MJ, Lockey RF, Turkeltaub PC, Platts-Mills TA. Survey of fatalities from skin testing and immunotherapy 1985-1989. Journal of Allergy and Clinical Immunology 1993;92:6-15.

\section{Skoner 2001}

Skoner DP. Allergic rhinitis: definition, epidemiology, pathophysiology, detection and diagnosis. Journal of Allergy and Clinical Immunology 2001;108:S2-S8. 


\section{Till 2004}

Till SJ, Francis JN, Nouri-Aria K, Durham SR. Mechanisms of immunotherapy. Journal of Allergy and Clinical Immunology 2004;113:1025-34.

\section{Viander 1978}

Viander M, Kiovikko A. The seasonal symptoms of hyposensitized and untreated hayfever patients in relation to birch pollen counts: correlations with nasal sensitivity, prick test and RAST. Clinical Allergy 1978;8:387-96.

\section{CHARACTERISTICS OF STUDIES}

Characteristics of included studies [ordered by study ID]

\section{Alvarez-Cuesta 2005}

\begin{tabular}{|c|c|c|}
\hline Methods & \multicolumn{2}{|c|}{ Randomised, double-blind, placebo controlled trial. } \\
\hline \multirow[t]{5}{*}{ Participants } & \multicolumn{2}{|l|}{ Country: Spain. } \\
\hline & \multicolumn{2}{|c|}{$\begin{array}{l}\text { Inclusion criteria: moderate SAR }(+), \text { SPT }(+) \text { and CAP }(+) \text { to grass pollen (Dactylis glomerata and Olea } \\
\text { europea). No previous SIT. }\end{array}$} \\
\hline & \multicolumn{2}{|c|}{ Total $n=57$. Active $n=25(12 m)$. Placebo $n=28(16 m)$} \\
\hline & \multicolumn{2}{|l|}{ Age range $18-58$ years. } \\
\hline & \multicolumn{2}{|c|}{ Five mild asthmatics ( 2 in active group) were included. } \\
\hline \multirow[t]{2}{*}{ Interventions } & \multirow{2}{*}{\multicolumn{2}{|c|}{$\begin{array}{l}\text { Treatment: standardised depigmented, polymerised extract (Lab LETI, S.L.). The median accumulated } \\
\text { dose of D. glomerata was } 1.48 \mathrm{mg} \text { (IQ range 1.44-2.83) and } 1.66 \mathrm{mg}(1.52-3.06) \text { of Olea europea. } \\
\text { Duration: } 3 \text { years ( } 2 \text { years as a pre-treatment monitoring period and } 1 \text { year as a treatment period - } \\
\text { placebo or SIT). }\end{array}$}} \\
\hline & & \\
\hline \multirow[t]{3}{*}{ Outcomes } & \multicolumn{2}{|c|}{ Symptom/medication scores recorded by patients during the pollen season. } \\
\hline & \multicolumn{2}{|l|}{ RQLQ. } \\
\hline & \multicolumn{2}{|l|}{ Adverse events. } \\
\hline \multicolumn{3}{|l|}{ Notes } \\
\hline \multicolumn{3}{|l|}{ Risk of bias } \\
\hline Bias & Authors' judgement & Support for judgement \\
\hline Allocation concealment? & Low risk & A - Adequate \\
\hline
\end{tabular}

\section{WHO 1998}

WHO. Allergen immunotherapy: therapeutic vaccines for allergic diseases. Allergy 1998;53 (44 Suppl):1-42.

Wilson DR, Torres Lima M, Durham SR. Sublingual immunotherapy for allergic rhinitis. Cochrane Database of Systematic Reviews 1999, Issue 2.

\section{Wilson 2005}

Wilson DR, Lima MT, Durham SR. Sublingual immunotherapy for allergic rhinitis: systematic review and meta-analysis. Allergy 2005;60 (1):4-12.

\section{Wilson 2003}


Ariano 1999 (Continued)

Inclusion criteria: all patients had single sensitisation to Parietaria grass pollen; SPT(++) and RAST (> class 2). Clinical symptoms for at least 2 years.

Total $n=25$; active group $n=13(4 m)$, placebo group $n=12(4 m)$.

Age range 13-62 years.

Five patients had mild intermittent asthma.

Interventions

Treatment: Parietaria judaica pollen/allergoid. Pre-seasonal dose given.

Treatment was given for 3 years.

Up-dosing: 1000, 2000, 4000, 6000, 8000, 10000, AUeq each week. Maintenance dose was 10000 AUeq monthly.

\begin{tabular}{ll}
\hline Outcomes & Symptoms/medication scores recorded by patient in diary cards during pollen seasons (March-Octo- \\
ber). & \\
Global assessment. & Adverse reactions. \\
& Skin reactivity by a standardised SPT at baseline and during year 3 of study. \\
& Allergen-specific lgG4 and IgE. \\
& Pollen counts. \\
\hline Notes & Authors' judgement Support for judgement \\
\hline Risk of bias & Low risk $\quad$ A - Adequate \\
\hline Bias & Allocation concealment?
\end{tabular}

\section{Armentia-Medina 1989}

\begin{tabular}{ll}
\hline Methods & Randomised, double-blind, placebo controlled trial. \\
\hline Participants & Country: Spain. \\
Inclusion criteria: SAR $(+)$ and SPT $(+)$ to Bermuda grass pollen (BGP). \\
Total $n=30$; active group $n=19$, placebo group $n=11$. \\
No distribution by sex reported. \\
21 patients had history of asthma. \\
Aged $12-55$ years. \\
\hline Rush IT protocol with Bermuda grass pollen. 17 total injections given. Pre-seasonal (Oct-Nov). Duration \\
of treatment was 4 days. Max dosage was 60 BU. \\
Patient symptoms assessed using a grade system (0-4 scale). \\
SPT by conventional prick test and the end point titration technique. \\
Non-specific bronchial hyperreactivity test with BGP.
\end{tabular}


Armentia-Medina 1989 (Continued)

$$
\begin{aligned}
& \text { Adverse reactions. } \\
& \text { Specific IgE and IgG to BGP. }
\end{aligned}
$$

\section{Notes}

\section{Risk of bias}

\begin{tabular}{lll}
\hline Bias & Authors' judgement & Support for judgement \\
\hline Allocation concealment? & Low risk & A-Adequate \\
\hline
\end{tabular}

\begin{tabular}{|c|c|}
\hline Methods & Randomised, double-blind, placebo controlled trial. \\
\hline \multirow[t]{4}{*}{ Participants } & Country: Sweden. \\
\hline & $\begin{array}{l}\text { Inclusion criteria: } \mathrm{SAR}(+)+/ \text { - seasonal asthma, } \mathrm{SPT}(+) \text {, RAST }(+) \text { and conjunctival provocation test }(+) \text { to } \\
\text { birch pollen. }\end{array}$ \\
\hline & Total $n=49 ;$ active group $n=24$ (9m, 9 asthmatics), placebo group $n=25$ (11m, 9 asthmatics). \\
\hline & Aged $19-45$ years. \\
\hline \multirow[t]{2}{*}{ Interventions } & Treatment: Alutard SQ Betula verrucosa (birch pollen) allergen extract aluminum hydroxide-adsorbed. \\
\hline & $\begin{array}{l}\text { Duration was } 2 \text { years after reaching maintenance. Initial concentration of } 100 \mathrm{SQ}-\mathrm{U} / \mathrm{ml} \text { and a maximum } \\
\text { concentration of } 100,000 \mathrm{SQ}-\mathrm{U} / \mathrm{ml} \text {. }\end{array}$ \\
\hline
\end{tabular}

Arvidsson 2002

Outcomes Symptoms/medication scores reported by patients in diary cards.

Adverse events.

Skin and conjunctival provocation test to birch pollen.

Pollen counts.

Bronchial Sx scores.

Notes

\section{Risk of bias}

\begin{tabular}{lll}
\hline Bias & Authors' judgement & Support for judgement \\
\hline Allocation concealment? & Low risk & A - Adequate \\
\hline
\end{tabular}

Balda 1998

\begin{tabular}{ll}
\hline Methods & Randomised, double-blind, placebo controlled trial. \\
\hline Participants & Country: Germany. \\
& Multicentre study: 14 University Allergy Departments.
\end{tabular}


Balda 1998 (Continued)

Inclusion criteria: $\mathrm{SAR}(+)$, SPT(+) CPT(+) and RAST(+) to alder, hazel or birch pollen.

Total $n=111$; active group $n=51(23 m)$ and placebo $n=60(25 m)$.

Age range 18 to 58 .

$>50 \%$ patients asthma.

Interventions Treatment: tree pollen allergen extract of Carylus avellana, Alnus glutinosa and Betula verrucosa for 7
weeks before the beginning of the tree-pollen season. Concentration of 10,100 and $1000 \mathrm{SE} / \mathrm{ml}$.

Symptoms/medication scores recorded by patients.
Nasal, bronchial symptoms.
Global assessment.
Adverse reactions.
Skin sensitivity.
Specific IgE and IgG4.
Eosinophil cationic protein.

Notes

\section{Risk of bias}

\begin{tabular}{lll}
\hline Bias & Authors' judgement & Support for judgement \\
\hline Allocation concealment? & Low risk & A - Adequate \\
\hline
\end{tabular}

\section{Bodtger 2002}

\begin{tabular}{ll}
\hline Methods & Randomised, double-blind, placebo controlled trial. \\
\hline Participants & Country: Denmark. \\
& Inclusion criteria: SAR $(+)+/$ - seasonal asthma, SPT $(+)$ and RAST $(+)$ to birch pollen. \\
& Total $n=35$; active group $n=17(7 \mathrm{~m}, 7$ asthmatics $)$, placebo group $n=18(7 \mathrm{~m}, 7$ asthmatics). \\
& Aged $19-46$ years. \\
\hline Interventions & Treatment: Alutard SQ Betula verrucosa (birch pollen) allergen extract aluminum hydroxide-adsorbed. \\
Clustered-injection schedule with an initial concentration of 10 SQ-U/ml and a maximum concentra- \\
tion of 100,000 SQ-U/ml. \\
Duration was 10 months.
\end{tabular}

\section{Outcomes}

Symptom/medication scores reported by patients in diary cards.

\section{Adverse events.}

Sensitivity to allergen provocation in skin, conjunctiva and nasal mucosa was measured before and after 10 months of treatment.

Total and specific IgE. 
Bodtger 2002 (Continued)

Notes

\section{Risk of bias}

\begin{tabular}{lll}
\hline Bias & Authors' judgement & Support for judgement \\
\hline Allocation concealment? & Low risk & A - Adequate \\
\hline
\end{tabular}

\section{Bousquet 1987a}

\begin{tabular}{|c|c|}
\hline Methods & Randomised, double-blind, placebo controlled trial. \\
\hline \multirow[t]{5}{*}{ Participants } & Country: France and Germany. \\
\hline & $\begin{array}{l}\text { Inclusion criteria: SAR }(+)+/ \text { - asthma }(+)+/ \text { - conjunctivitis }(+) \text {, SPT }(+) \text { and RAST (> class } 3-4 \text { ) to Orchard } \\
\text { grass pollen. }\end{array}$ \\
\hline & Total $n=45 ;$ grass pollen extract group $n=15$, allergoid group $n=19$ and placebo group $n=11$. \\
\hline & No distribution by sex reported. \\
\hline & More than $50 \%$ patients had asthma $+/$ - conjunctivitis. \\
\hline Interventions & $\begin{array}{l}\text { Treatment: standardised orchard grass-pollen extract, six-mixed grass-pollen allergoid. Rush IT proto- } \\
\text { col used for } 4 \text { days. Pre-seasonal. } 9 \text { injections given with pollen extract and } 10 \text { injections given with al- } \\
\text { lergoid. Max dosage: } 2 \text { IR pollen extract and } 1000 \text { PNU allergoid. }\end{array}$ \\
\hline
\end{tabular}

\section{Outcomes}

\section{Patient symptoms score recorded in diary cards.}

Skin test titration.

Adverse events.

Serum orchard grass-pollen IgE and IgG.

Pollen counts.

\section{Notes}

\section{Risk of bias}

\begin{tabular}{lll}
\hline Bias & Authors' judgement & Support for judgement \\
\hline Allocation concealment? & Low risk & A - Adequate \\
\hline
\end{tabular}

Bousquet 1987b

Methods Randomised, double-blind, placebo controlled trial.

\section{Participants}

$$
\begin{aligned}
& \text { Country: France. } \\
& \text { Inclusion criteria: patients with severe SAR to orchard grass pollen. } \\
& \text { Total } n=59 \text {; active group } n=39 \text {, placebo group } n=20 \text {. } \\
& \text { No distribution by sex reported. }
\end{aligned}
$$


Bousquet 1987b (Continued)

Adults.

\begin{tabular}{|c|c|c|}
\hline Interventions & \multicolumn{2}{|c|}{$\begin{array}{l}\text { Treatment: High-molecular weight formalinised allergoid with orchard grass pollen. Injections } n=9 \text {, } \\
\text { given pre-seasonally. Dosage used 5,695 to } 73,800 \text { PNU. }\end{array}$} \\
\hline Outcomes & \multicolumn{2}{|c|}{ Symptoms recorded by patients. } \\
\hline & \multicolumn{2}{|l|}{ Adverse events. } \\
\hline & \multicolumn{2}{|c|}{ Nasal provocation test before and after IT. } \\
\hline & \multicolumn{2}{|c|}{ Serum grass pollen IgG. } \\
\hline \multicolumn{3}{|l|}{ Notes } \\
\hline \multicolumn{3}{|l|}{ Risk of bias } \\
\hline Bias & Authors' judgement & Support for judgement \\
\hline Allocation concealment? & Low risk & A - Adequate \\
\hline
\end{tabular}

\section{Bousquet 1988}

\begin{tabular}{|c|c|}
\hline Methods & Randomised, double-blind, placebo controlled trial. \\
\hline \multirow[t]{4}{*}{ Participants } & Country: France and Germany. \\
\hline & $\begin{array}{l}\text { Inclusion criteria: patients with severe SAR to orchard grass pollen. SPT }(+) \text { and RAST }(+) \text { to orchard grass } \\
\text { pollen. }\end{array}$ \\
\hline & Total $n=25$; active group $n=15$, placebo group $n=10$. \\
\hline & 15 males. Adults. \\
\hline
\end{tabular}
Interventions Treatment: High-molecular weight formalinised allergoid with orchard grass pollen. Injections $\mathrm{n}=9$, given pre-seasonally. Initial dose 50 PNU last dose 2000 PNU.

\begin{tabular}{ll}
\hline Outcomes & Symptoms recorded by patients. \\
& Nasal provocation test before and after IT. \\
& SPT to orchard extracts. \\
& Serum grass pollen IgG and IgE. \\
\hline Notes & \\
\hline Risk of bias & Authors' judgement $\quad$ Support for judgement \\
\hline Bias & Low risk $\quad$ A - Adequate \\
\hline Allocation concealment?
\end{tabular}


Bousquet 1989

\begin{tabular}{|c|c|c|}
\hline Methods & \multicolumn{2}{|c|}{ Randomised, double-blind, placebo controlled trial. } \\
\hline \multirow[t]{5}{*}{ Participants } & \multicolumn{2}{|c|}{ Country: France and Germany. } \\
\hline & \multicolumn{2}{|c|}{$\begin{array}{l}\text { Inclusion criteria: patients with severe SAR to orchard grass pollen. SPT }(+) \text { and RAST }(+) \text { to orchard grass } \\
\text { pollen. }\end{array}$} \\
\hline & \multicolumn{2}{|c|}{$\begin{array}{l}\text { Total } n=60 ; \text { GOID group } n=15 \text {, HMW-GOID group } n=13 \text {, standardised extract group } n=18 \text {, placebo } \\
\text { group } n=14 \text {. }\end{array}$} \\
\hline & \multicolumn{2}{|l|}{ Adults. } \\
\hline & \multicolumn{2}{|c|}{ Some patients were asthmatics. } \\
\hline Interventions & \multicolumn{2}{|c|}{$\begin{array}{l}\text { Treatment: High-molecular weight formalinised allergoid (HMW-GOID) with orchard grass pollen and } \\
\text { HMG-fractionated by gel filtration (molecules }>85,000 \text { daltons, GOID). Injections } n=9 \text {, given pre-sea- } \\
\text { sonally. Initial dose } 50 \text { PNU last dose } 2000 \text { PNU. }\end{array}$} \\
\hline \multirow[t]{4}{*}{ Outcomes } & \multicolumn{2}{|c|}{ Symptoms recorded by patients. } \\
\hline & \multicolumn{2}{|c|}{ SPT to orchard extracts. } \\
\hline & \multicolumn{2}{|c|}{ Adverse events recorded. } \\
\hline & \multicolumn{2}{|c|}{ Serum grass pollen IgG and IgE. } \\
\hline \multicolumn{3}{|l|}{ Notes } \\
\hline \multicolumn{3}{|l|}{ Risk of bias } \\
\hline Bias & Authors' judgement & Support for judgement \\
\hline Allocation concealment? & Low risk & A - Adequate \\
\hline
\end{tabular}

\section{Bousquet 1990}

Methods Randomised, double-blind, placebo controlled trial.

Participants

Country: France.

Inclusion criteria: patients with severe SAR to orchard grass pollen. SPT(+) and RAST $(+)$ to orchard grass pollen.

Total $n=57$; high dosage group $n=20$, low dosage group $n=19$, placebo group $n=18$.

Adults, 24 males.

Some patients were asthmatics.

Interventions Treatment: High-molecular weight formalinised allergoid with orchard grass pollen. Two groups: high dose schedule with a maximal dose of 10,000 PNU and a low-dose schedule with a maximal dose of 2,000 PNU. 10 injections were given pre-seasonally. Initial dose 100 PNU.

\section{Outcomes}

\section{Symptoms recorded by patients.}

Medication scores.

SPT and NPT to orchard extracts. 
Bousquet 1990 (Continued)

Adverse events recorded.

Serum grass pollen IgG and IgE.

\section{Notes}

\section{Risk of bias}

\begin{tabular}{lll}
\hline Bias & Authors' judgement & Support for judgement \\
\hline Allocation concealment? & Low risk & A-Adequate \\
\hline
\end{tabular}

\section{Bousquet 1991}

\begin{tabular}{|c|c|}
\hline Methods & Randomised, double-blind, placebo controlled trial. \\
\hline \multirow[t]{4}{*}{ Participants } & Country: France and Germany. \\
\hline & $\begin{array}{l}\text { Inclusion criteria: patients with SAR symptoms (April - July), SPT (+) and RAST (+) to orchard grass } \\
\text { pollen. No previous IT. }\end{array}$ \\
\hline & $\begin{array}{l}\text { Total } n=70 ; 36 \text { patients allergic only to grass pollens received single-allergen (orchard grass pollen) ex- } \\
\text { tracts injections or placebo and } 34 \text { patients allergic to multiple-pollen species received mixed allergen } \\
\text { extract injections or placebo. }\end{array}$ \\
\hline & Aged 14 to 44 years. No sex distribution reported. \\
\hline Interventions & $\begin{array}{l}\text { Pre-seasonal treatment with standardised extracts from orchard grass were given for } 3 \text { days in up-dos- } \\
\text { ing phase (max dosage } 2000 \mathrm{BU} \text { ). Maintenance dose of } 2000 \mathrm{BU} \text { was administrated five times at weekly } \\
\text { intervals. }\end{array}$ \\
\hline
\end{tabular}

Symptom/medication scores.
Nasal challenges.
Titration of mediators in nasal secretions.
SPTs.
Adverse reactions.
Serum orchard grass pollen IgG and IgE.
Pollen counts.
pollen extracts every 2 weeks during the pollen season.

\section{Risk of bias}

\begin{tabular}{lll}
\hline Bias & Authors' judgement & Support for judgement \\
\hline Allocation concealment? & Low risk & A - Adequate \\
\hline
\end{tabular}


Brewczynski 1999

\begin{tabular}{|c|c|c|}
\hline Methods & \multicolumn{2}{|c|}{ Randomised, double-blind, placebo controlled trial. } \\
\hline \multirow[t]{5}{*}{ Participants } & \multicolumn{2}{|l|}{ Country: Germany. } \\
\hline & \multicolumn{2}{|c|}{ Inclusion criteria: patients with SAR symptoms, SPT(+) and RAST(+) to grass pollen. No previous IT. } \\
\hline & \multicolumn{2}{|c|}{ Total $n=20$; active group $n=10(4 m)$, placebo group $n=10(6 m)$. } \\
\hline & \multicolumn{2}{|l|}{ Aged 14 to 34 years. } \\
\hline & \multicolumn{2}{|c|}{ Some patients were asthmatics. } \\
\hline Interventions & \multicolumn{2}{|c|}{$\begin{array}{l}\text { Treatment: modified extract (allergoid) was used. Pre-seasonal treatment given. Duration of treatment } \\
\text { was } 3 \text { years. Cumulative dose was 120,000 AU per year. }\end{array}$} \\
\hline \multirow[t]{3}{*}{ Outcomes } & \multicolumn{2}{|c|}{ Symptom/medication scores in diary cards. } \\
\hline & \multicolumn{2}{|l|}{ Adverse events. } \\
\hline & \multicolumn{2}{|c|}{ Grass pollen specific IgE and IgG antibody levels. } \\
\hline Notes & \multicolumn{2}{|c|}{ Paper was translated from German } \\
\hline \multicolumn{3}{|l|}{ Risk of bias } \\
\hline Bias & Authors' judgement & Support for judgement \\
\hline Allocation concealment? & Unclear risk & B - Unclear \\
\hline
\end{tabular}

Brunet 1992a

\begin{tabular}{|c|c|}
\hline Methods & Randomised, double-blind, placebo controlled trial. \\
\hline Participants & $\begin{array}{l}\text { Country: Canada. } \\
\text { Inclusion criteria: clear-cut history SAR without asthma, SPT }(+) \text { and RAST }(+) \text { to ragweed. } \\
\text { Total } n=40 \text {; active group } n=13(10 \mathrm{~m}) \text {, placebo group } n=14(8 \mathrm{~m}) \text { and control group } n=13(8 \mathrm{~m}) \text {. } \\
\text { Aged } 19 \text { to } 56 \text { years. }\end{array}$ \\
\hline Interventions & $\begin{array}{l}\text { Treatment: Alum-precipitated aqueous ragweed extracts. Pres-seasonal dosage was given in } 9 \text { consec- } \\
\text { utive weeks ( } \max 3000 \mathrm{PNU} \text { ). } \\
\text { Maintenance dose and duration was not reported. }\end{array}$ \\
\hline Outcomes & $\begin{array}{l}\text { Symptom/medication score recorded in dairy cards. } \\
\text { Adverse events. } \\
\text { Nasal challenge. } \\
\text { Ragweed-induced basophil histamine release. } \\
\text { Ragweed-specific IgE and IgG antibody levels. }\end{array}$ \\
\hline Notes & A non-atopic volunteer group ( $n=13$, with negative SPT and RAST) were used as control group \\
\hline
\end{tabular}


Brunet 1992a (Continued)

Risk of bias

\begin{tabular}{lll}
\hline Bias & Authors' judgement & Support for judgement \\
\hline Allocation concealment? & Low risk & A - Adequate \\
\hline
\end{tabular}

Ceuppens 2004

\begin{tabular}{|c|c|}
\hline Methods & Randomised, double-blind, placebo controlled trial. \\
\hline \multirow[t]{4}{*}{ Participants } & Country: Belgium and the Netherlands. \\
\hline & $\begin{array}{l}\text { Inclusion criteria: Birch allergic mono-sensitised patients. Total } n=78 \text {. Active } n=39(18 \mathrm{~m}) \text {. Placebo }=39 \\
(17 \mathrm{~m}) \text {. }\end{array}$ \\
\hline & 38 patients had mild-moderate seasonal asthma (16 in active group). \\
\hline & Median age range was $45 \mathrm{yrs}$. \\
\hline \multirow[t]{2}{*}{ Interventions } & $\begin{array}{l}\text { Treatment: Glutaraldehyde-modified allergen extract from birch pollen adsorbed onto aluminium hy- } \\
\text { droxide (PURETHAL). Six injections given. }\end{array}$ \\
\hline & Duration: 1 year. \\
\hline
\end{tabular}

Outcomes Symptom/medication scores recorded by patients during the pollen season.

Adverse events.

Serum slgE, slgG

\begin{tabular}{lll}
\hline Notes \\
\hline Risk of bias \\
\hline Bias & Authors' judgement & Support for judgement \\
\hline Allocation concealment? & Unclear risk & D - Not used \\
\hline
\end{tabular}

\section{Charpin 2003}

\begin{tabular}{|c|c|}
\hline Methods & Randomised, double-blind, placebo controlled trial. \\
\hline \multirow[t]{5}{*}{ Participants } & Country: France. \\
\hline & Inclusion criteria: Moderate to severe European cypress SAR \\
\hline & Total $n=40$. Active $n=22(? m)$. Placebo $=18(? m)$ \\
\hline & Adults. \\
\hline & No asthma data given. \\
\hline Interventions & $\begin{array}{l}\text { Treatment: standardised depot Juniperus ashei extract with a potency of } 100 \mathrm{IR} \text { containing } 54 \text { ug Jun } \\
\text { a1/ml (Alustal, Stallergenes). Two weekly injections }(0.1 \mathrm{IR} / \mathrm{ml}) \text { were given until reach maintenance } \\
\text { dose of } 0.3 \mathrm{ml} \text { of the } 100 \mathrm{IR} \text { concentration. }\end{array}$ \\
\hline Outcomes & Symptom/medication scores recorded by patients during the pollen season. \\
\hline
\end{tabular}


Charpin 2003 (Continued)

Adverse events.

Notes

\section{Risk of bias}

\begin{tabular}{lll}
\hline Bias & Authors' judgement & Support for judgement \\
\hline Allocation concealment? & Unclear risk & D - Not used \\
\hline
\end{tabular}

\section{Corrigan 2005}

\begin{tabular}{ll}
\hline Methods & Randomised, double-blind, placebo controlled trial. \\
\hline Participants & Country: UK and Germany. \\
Inclusion criteria: SAR $(+)$, SPT $(+)$ and CPT $(+)$ to grass pollen. No SIT previous last 3 yrs. \\
Total $n=154$. Active $n=77(35 \mathrm{~m})$. Placebo $=77(29 \mathrm{~m})$. \\
Age range $18-60$ yrs. \\
$\begin{array}{ll}42 \text { mild-moderate asthmatics }(19 \text { in active group) were included. } \\
\text { Treatment: Allergoid absorbed extracts of six grass pollen allergens (Holcus lantus, Dactylis glomerata, } \\
\text { Lolium perenne, Phleum pratene, Poa pratensis, Festula pratensis) co-precipitated with aluminium hy- } \\
\text { droxide. Two concentrations used } 1,000 \text { TU/ml and 10,000 TU/ml (Allergovit, Allergopharma). Average } \\
\text { number of injections was } 9 \text { per year. Median values of maximum study dose given was 6,000 TU. Dura- } \\
\text { tion was two consecutive pre-seasons. }\end{array}$ \\
\hline
\end{tabular}

Symptom/medication scores recorded by patients during the pollen season.
RQLQ.
CPT.
Adverse events.
slgE, slgG1 and slgG4.

\section{Notes}

\section{Risk of bias}

\begin{tabular}{lll}
\hline Bias & Authors' judgement & Support for judgement \\
\hline Allocation concealment? & Low risk & A - Adequate \\
\hline
\end{tabular}

\section{D'Amato 1995}

\begin{tabular}{ll}
\hline Methods & Randomised, double-blind, placebo controlled trial. \\
\hline Participants & Country: Italy and USA. \\
& $\begin{array}{l}\text { Inclusion criteria: history of rhinitis }+/- \text { asthma during the Parietaria pollen season with SPT }(+), \text { nasal } \\
\text { provocation test }(+) \text { and RAST }(>\text { class } 2) \text { to Parietaria. }\end{array}$
\end{tabular}


D'Amato 1995 (Continued)

Total $n=36$; active group $n=19(10 m)$ and placebo group $n=17(10 m)$.

Mean age range 28.6 (active) and 34.6 (placebo).

Seven patients had asthma.

Interventions

Treatment: Alum adsorbed partially purified Parietaria extract. No up-dosing dosage and time-table reported. Targeted maintenance dose was 12,500 BU for 3 years.

Outcomes Symptom/medication score recorded in diary cards using VAS.

Adverse reactions.

Nasal provocation tests.

Skin test suppression.

Global improvement.

Pollen count.

\section{Notes}

\section{Risk of bias}

\begin{tabular}{lll}
\hline Bias & Authors' judgement & Support for judgement \\
\hline Allocation concealment? & Unclear risk & B - Unclear \\
\hline
\end{tabular}

\section{Dolz 1996}

\begin{tabular}{ll}
\hline Methods & Randomised, double-blind, placebo controlled trial. \\
\hline Participants & Country: Spain. \\
& Inclusion criteria: clinical history of SAR. SPT $(+)$ CPT $(+)$ and RAST + ) to grass pollen. Total $n=28 ;$ active \\
& group $n=18$ and placebo $n=10$. \\
& Age range 15 to 35 years. \\
& Six patients had mild seasonal asthma. \\
& No sex distribution given. \\
\hline Interventions & Treatment: grass pollen allergen extract Allutard SQ aluminum hydroxide-adsorbed Phleum, Dactylis \\
and Lolium for 3 years. Initial concentration of 100 USQ/ml and a maximum concentration of 100 000 \\
USQ/ml. \\
Symptom/medication scores recorded by patients. \\
Adverse reactions. \\
Conjunctival, skin and bronchial provocation tests. \\
Total serum IgE. Specific IgG
\end{tabular}

\section{Notes}

\section{Risk of bias}

Allergen injection immunotherapy for seasonal allergic rhinitis (Review) 
Dolz 1996 (Continued)

\begin{tabular}{lll} 
Bias & Authors' judgement & Support for judgement \\
\hline Allocation concealment? & Low risk & A - Adequate \\
\hline
\end{tabular}

\section{Drachenberg 2001}

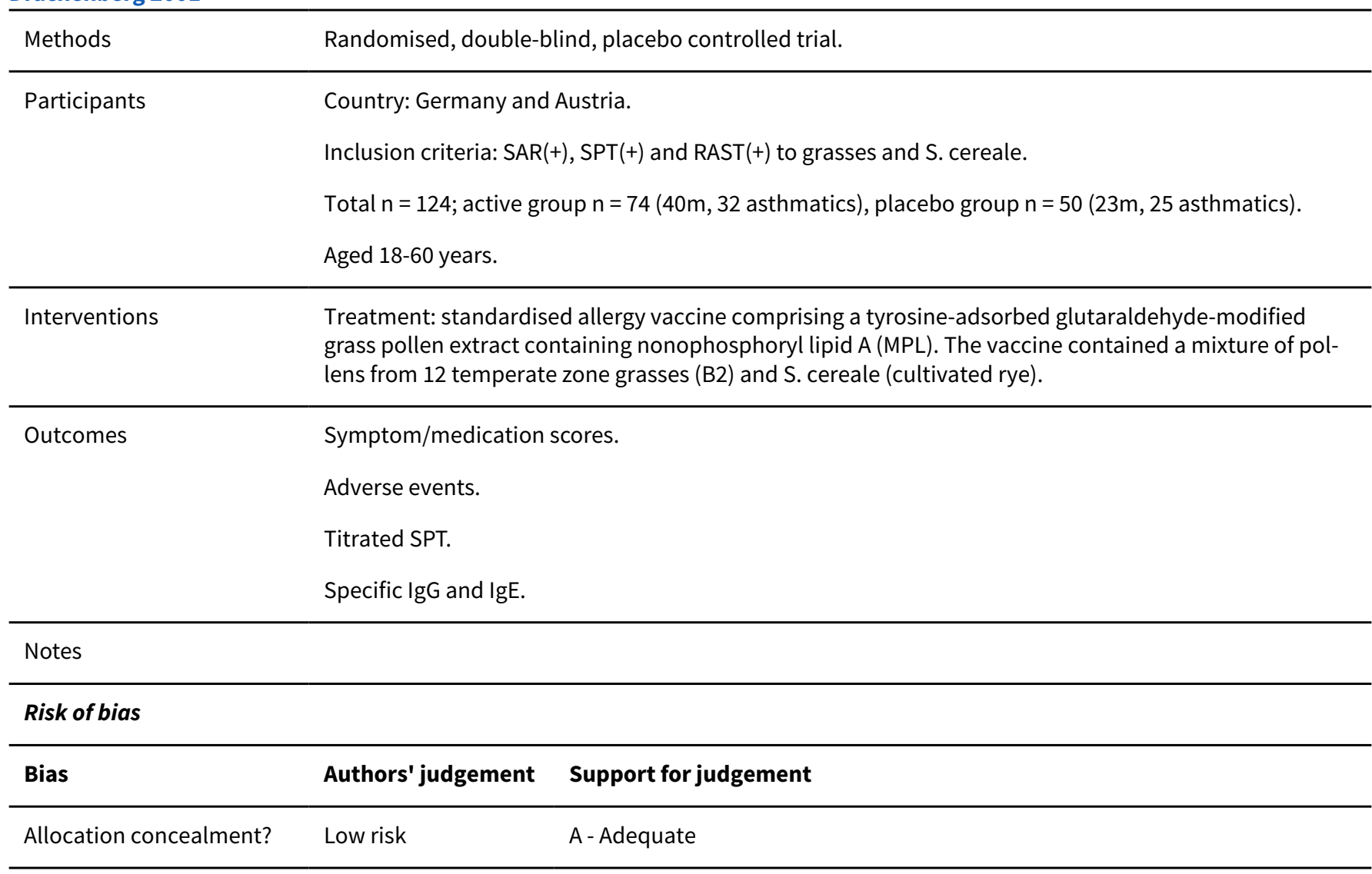

\section{Drachenberg 2002}

\begin{tabular}{ll}
\hline Methods & Randomised, double-blind, placebo controlled trial. \\
\hline Participants & Country: Germany. \\
& Inclusion criteria: SAR + ), conjunctivitis +/- asthma sensitised to birch, alder, hazel pollen. \\
& Total $n=84$; active group $n=54$, placebo group $n=27$. \\
& Aged $18-61$ years. \\
\hline Interventions & $\begin{array}{l}\text { Treatment: The active group received } 4 \text { injections of L-tyrosine-adsrobed tree pollen allergoids plus } 50 \\
\text { micrograms/mL monophosphoryl-lypid-A (MPL). Placebo injections consisted of L-tyrosine-solution } \\
(2 \%) \text { in excipient solution. }\end{array}$ \\
\hline Outcomes & Combined symptom/medication scores. \\
Changes in skin reactivity (titrated SPT).
\end{tabular}


Drachenberg 2002 (Continued)

\author{
Adverse events. \\ Specific IgG and IgE.
}

\title{
Notes
}

\section{Risk of bias}

\begin{tabular}{lll}
\hline Bias & Authors' judgement & Support for judgement \\
\hline Allocation concealment? & Low risk & A-Adequate \\
\hline
\end{tabular}

\section{Ferrer 2005}

\begin{tabular}{ll}
\hline Methods & Randomised, double-blind, placebo controlled trial. \\
\hline Participants & Country: Spain. \\
& Inclusion criteria: SAR $(+)$ and SPT $(+)$ to Parietaria judaica. Total $n=57$. Active $n=28(11 \mathrm{~m})$. Placebo $=$ \\
& $29(15 \mathrm{~m})$. \\
& Age range $15-55$ yrs. \\
& 23 patients had mild-moderate seasonal asthma (13 in active group). \\
\hline Interventions & Treatment: Parietaria judaica extract 25 BU/ml $(1.5$ ug $/ \mathrm{ml}$ Par $\mathrm{j} 1)$, Pangramin Depot, ALK-Abello. Mean \\
number of injections for each patient was $29.3 \pm 6.2$. All patients in active group reached the predeter- \\
mined maintenance dose of 29 BU. \\
Duration: 20 months. \\
Symptom/medication scores recorded by patients during the pollen season. \\
Adverse events. \\
RQLQ. \\
Immediate and late cutaneous response.
\end{tabular}

\section{Notes}

\section{Risk of bias}

\begin{tabular}{lll}
\hline Bias & Authors' judgement & Support for judgement \\
\hline Allocation concealment? & Low risk & A- Adequate \\
\hline
\end{tabular}

\section{Fling 1989}

Methods Randomised, double-blind, placebo controlled trial.

Country: USA.
Inclusion criteria: typical history of SAR and SPT $(+4)$ to mountain cedar pollen.
Total $n=19$; active group $n=12(2 \mathrm{~m})$ and placebo group $n=7(3 \mathrm{~m})$.


Fling 1989 (Continued)

$$
\text { Aged 18-70 years. }
$$

Interventions $\quad$ Treatment: Conventional IT with mountain cedar antigen beginning at a 1:100,000 wt/vol dilution and progressing by $0.05 \mathrm{ml}$ increments until $0.5 \mathrm{ml}$ was achieved. Then, a 10 -fold higher concentration was given in the same dosing increments until maintenance was reached at $0.5 \mathrm{ml}$ of $1: 100 \mathrm{wt} / \mathrm{vol}$ or the highest tolerated dose.

Outcomes

Patient symptom/medication scores.

Adverse events.

Cutaneous (early and late reactions).

Allergen-specific IgE, IgG. IgG1 and IgG4.

Pollen counts.

\section{Notes}

\section{Risk of bias}

\begin{tabular}{lll}
\hline Bias & Authors' judgement & Support for judgement \\
\hline Allocation concealment? & Low risk & A - Adequate \\
\hline
\end{tabular}

Frew 2006

\begin{tabular}{ll}
\hline Methods & Randomised, double-blind, placebo controlled trial. \\
\hline Participants & Country: UK. \\
& Inclusion criteria: SAR $(+)$ inadequately controlled with standard medication. SPT $(+)$ and CAP $(+)>$ class \\
& 2 to Phleum pratense. No SIT previous 5 yrs. \\
& Total $n=410$. Active group 100,000 SQ-U $n=203(110 \mathrm{~m}), 10,000$ SQ-U $n=104(59 m)$. Placebo group $n=$ \\
& $103(62 \mathrm{~m})$. \\
& Age range: $18-60$ yrs. \\
& Mild-moderate seasonal asthmatics were included.
\end{tabular}

Treatment: standardised depot preparations of grass pollen extract (Alutard SQ-U Phleum pratense,
ALK-Abello) were given by subcutaneous injection. The up-dosing phase consisted of 15 injections over
8 weeks. At each visit, $8 \mathrm{mg}$ Acrivastine was given 15 mins before first injection, second injection was
given 30 mins later. Maintenance injections given $6 \pm 2$ weeks.
Duration: 1 year

\begin{tabular}{ll}
\hline Outcomes & Symptom/medication scores recorded by patients during the pollen season. \\
& Nasal, eye and lung symptoms were recorded. \\
Global assessment. & Rhinoconjunctivitis RQLQ. \\
Adverse events & Alutard Phleum pratense 100,000 SQ-U (ALK-Abello) corresponds to $20 \mu$ g of major allergen Phl p 5. \\
\hline Notes
\end{tabular}


Frew 2006 (Continued)

\section{Risk of bias}

\begin{tabular}{lll}
\hline Bias & Authors' judgement & Support for judgement \\
\hline Allocation concealment? & Low risk & A - Adequate \\
\hline
\end{tabular}

Grammer 1982

\begin{tabular}{|c|c|c|}
\hline Methods & \multicolumn{2}{|c|}{ Randomised, double-blind, placebo controlled trial. } \\
\hline \multirow[t]{5}{*}{ Participants } & \multicolumn{2}{|c|}{ Country: USA. } \\
\hline & \multicolumn{2}{|c|}{ Inclusion criteria: SAR(+) and SPT(+4) to ragweed. } \\
\hline & \multicolumn{2}{|c|}{ Total $n=40 ;$ active group $n=21$ and placebo $n=19$} \\
\hline & \multicolumn{2}{|l|}{ Aged 21-65 years. } \\
\hline & \multicolumn{2}{|c|}{ No sex distribution given. } \\
\hline \multirow[t]{2}{*}{ Interventions } & \multirow{2}{*}{\multicolumn{2}{|c|}{$\begin{array}{l}\text { Treatment: Polymerised ragweed. Pre-seasonal treatment given. } \\
\text { Duration of treatment was } 15 \text { weeks, one injection weekly. Max dosage given was } 6250 \text { PNU per injec- } \\
\text { tion. }\end{array}$}} \\
\hline & & \\
\hline \multirow[t]{3}{*}{ Outcomes } & \multicolumn{2}{|c|}{ Patient symptom score. } \\
\hline & \multicolumn{2}{|l|}{ Adverse events. } \\
\hline & \multicolumn{2}{|c|}{ Total serum antibody against ragweed antigen $\mathrm{E}$. } \\
\hline Notes & \multicolumn{2}{|c|}{ Additional control group $(n=15)$ received no injections. } \\
\hline \multicolumn{3}{|l|}{ Risk of bias } \\
\hline Bias & Authors' judgement & Support for judgement \\
\hline Allocation concealment? & Low risk & A - Adequate \\
\hline
\end{tabular}

Grammer 1983

\begin{tabular}{ll}
\hline Methods & Randomised, double-blind, placebo controlled trial. \\
\hline Participants & Country: USA. \\
& Inclusion criteria: SAR $(+)$ and SPT $(+4)$ to grass pollen. \\
& Total $n=26$; active group $n=13$ and placebo $n=13$. \\
& Aged $21-65$ years. \\
& No sex distribution given. \\
\hline Interventions & Treatment: Polymerised grass extracts of rye, timothy, redtop, June, orchard and Bermuda. In 12 week- \\
& ly injections the active group received approximately 48,000 PNU. \\
\hline
\end{tabular}


Grammer 1983 (Continued)

Patient symptom/medication score.
Adverse events.
Specific IgE.
Pollen count.

Notes

\section{Risk of bias}

\begin{tabular}{lll}
\hline Bias & Authors' judgement & Support for judgement \\
\hline Allocation concealment? & Low risk & A - Adequate \\
\hline
\end{tabular}

Grammer 1984a

\begin{tabular}{|c|c|c|}
\hline Methods & \multicolumn{2}{|c|}{ Randomised, double-blind, placebo controlled trial. } \\
\hline \multirow[t]{5}{*}{ Participants } & \multicolumn{2}{|c|}{ Country: USA. } \\
\hline & \multicolumn{2}{|c|}{ Inclusion criteria: SAR(+) and SPT(4+) to ragweed. } \\
\hline & \multicolumn{2}{|c|}{ Total $n=42 ;$ active group $n=21$ and placebo $n=21$. } \\
\hline & \multicolumn{2}{|l|}{ Aged $21-65$ years. } \\
\hline & \multicolumn{2}{|c|}{ No sex distribution given. } \\
\hline Interventions & \multicolumn{2}{|c|}{$\begin{array}{l}\text { Treatment: Polymerised ragweed. Pre-seasonal treatment given. } \\
\text { Dosage schedule was a series of } 4 \text { weekly injections. No max dosage and time reported. }\end{array}$} \\
\hline Outcomes & \multicolumn{2}{|c|}{ Patient symptom/medication score. } \\
\hline & \multicolumn{2}{|l|}{ Adverse events. } \\
\hline & \multicolumn{2}{|c|}{ Total serum antibody against ragweed antigen E. } \\
\hline \multicolumn{3}{|l|}{ Notes } \\
\hline \multicolumn{3}{|l|}{ Risk of bias } \\
\hline Bias & Authors' judgement & Support for judgement \\
\hline Allocation concealment? & Low risk & A - Adequate \\
\hline
\end{tabular}

\section{Grammer 1984b}

\begin{tabular}{ll}
\hline Methods & Randomised, double-blind, placebo controlled trial. \\
\hline Participants & Country: USA. \\
& Inclusion criteria: SAR $(+)$ and SPT $(+)$ to ragweed. \\
& Total $n=50$; active group $n=19(13 \mathrm{~m})$ and placebo $n=31(23 \mathrm{~m})$. \\
\hline
\end{tabular}


Grammer 1984b (Continued)

Asthmatics $n=8$ in active group and $n=15$ in placebo group.

Interventions Treatment: Polymerised ragweed. In 15 weekly injections the active group received 50,000 PNU of ragweed, equivalent to $1200 \mathrm{mcg}$ antigen. No max dose and timetable reported.

Outcomes Patient symptom/medication score.

Adverse events.

Total serum antibody against ragweed antigen $\mathrm{E}$.

Notes

\section{Risk of bias}

\begin{tabular}{lll}
\hline Bias & Authors' judgement & Support for judgement \\
\hline Allocation concealment? & Low risk & A - Adequate \\
\hline
\end{tabular}

Grammer 1986

\begin{tabular}{|c|c|c|}
\hline Methods & \multicolumn{2}{|c|}{ Randomised, double-blind, placebo controlled trial. } \\
\hline \multirow[t]{3}{*}{ Participants } & \multicolumn{2}{|l|}{ Country: USA. } \\
\hline & \multicolumn{2}{|c|}{$\begin{array}{l}\text { Inclusion criteria: SAR(+) and SPT(+) to either timothy, orchard or Bermuda grass pollen. Patients were } \\
\text { paired on the basis of cutaneous end point titrations to timothy, orchard and Bermuda grass pollen ex- } \\
\text { tracts. }\end{array}$} \\
\hline & \multicolumn{2}{|c|}{$\begin{array}{l}\text { Total } n=44 ; n=15 \text { received } 3 \text { grasses, } n=4 \text { received } 2 \text { grasses and } n=1 \text { received one grass. Placebo } \\
\text { group } n=20 \text {. }\end{array}$} \\
\hline \multirow[t]{2}{*}{ Interventions } & \multirow{2}{*}{\multicolumn{2}{|c|}{$\begin{array}{l}\text { Treatment: individually polymerised grass immunotherapy with an accelerated dosage schedule. } \\
\text { Duration: } 9 \text { weekly visits with } 13 \text { injections that totalled } 24,000 \text { PNU of each grass to which the patient } \\
\text { had cutaneous reactivity. }\end{array}$}} \\
\hline & & \\
\hline \multirow[t]{4}{*}{ Outcomes } & \multicolumn{2}{|c|}{ Patient symptom/medication score. } \\
\hline & \multicolumn{2}{|l|}{ Adverse events. } \\
\hline & \multicolumn{2}{|c|}{ Specific serum IgE and IgG. } \\
\hline & \multicolumn{2}{|l|}{ Pollen count. } \\
\hline \multicolumn{3}{|l|}{ Notes } \\
\hline \multicolumn{3}{|l|}{ Risk of bias } \\
\hline Bias & Authors' judgement & Support for judgement \\
\hline Allocation concealment? & Low risk & A - Adequate \\
\hline
\end{tabular}


Grammer 1987

\begin{tabular}{|c|c|}
\hline Methods & Randomised, double-blind, placebo controlled trial. \\
\hline \multirow[t]{5}{*}{ Participants } & Country: USA. \\
\hline & $\begin{array}{l}\text { Inclusion criteria: typical history of SAR to ragweed. Must had at least } 30 \mathrm{~mm} \text { sum of erythema to prick } \\
\text { testing with } 100,000 \mathrm{AU} / \mathrm{ml} \text { ragweed extracts. }\end{array}$ \\
\hline & Aged 21 to 60 \\
\hline & Total $n=81 ;$ active group $n=36$ and placebo $n=37$. Sex distribution no reported. \\
\hline & Asthmatics $n=12$. \\
\hline Interventions & $\begin{array}{l}\text { Treatment: Polymerised ragweed. Patients received } 15 \text { injections in } 15 \text { weekly visits. No max dose and } \\
\text { timetable reported. }\end{array}$ \\
\hline Outcomes & Patient symptom/medication score. \\
\hline & Adverse events. \\
\hline & IgE and IgE antibody against ragweed levels. \\
\hline \multicolumn{2}{|l|}{ Notes } \\
\hline \multicolumn{2}{|l|}{ Risk of bias } \\
\hline Bias & Support for judgement \\
\hline Allocation concealment? & A - Adequate \\
\hline
\end{tabular}

\section{Hauser 1995}

Methods Randomised, double-blind, placebo controlled trial.

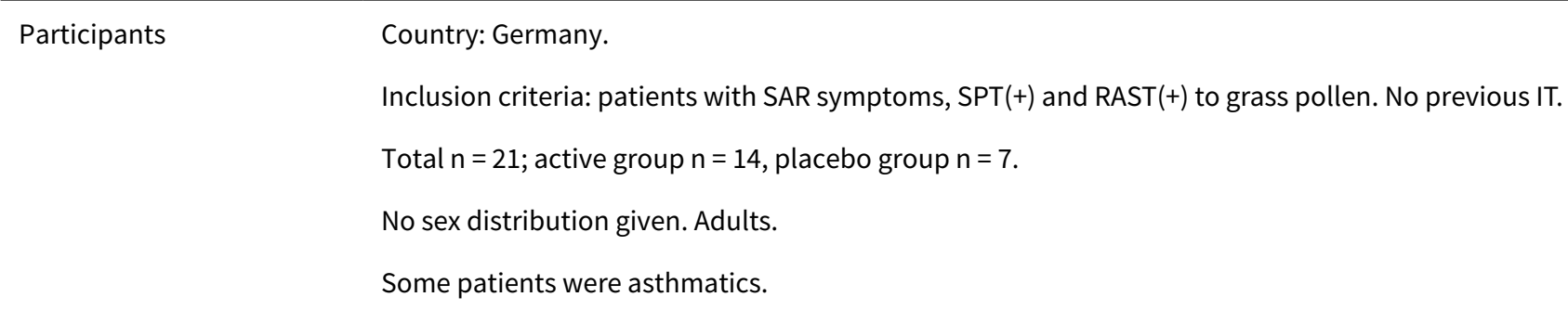

Outcomes Symptom/medication scores in diary cards.

Nasal allergen challenge.

Number of eosinophils and IgE-positive cells in nasal mucosa.

Notes Paper was translated from German.

\section{Risk of bias}


Hauser 1995 (Continued)

\begin{tabular}{lll} 
Bias & Authors' judgement & Support for judgement \\
\hline Allocation concealment? & Unclear risk & B - Unclear \\
\hline
\end{tabular}

\section{Hauser 1997}

\begin{tabular}{|c|c|c|}
\hline Methods & \multicolumn{2}{|c|}{ Randomised, double-blind, placebo controlled trial. } \\
\hline \multirow[t]{5}{*}{ Participants } & \multicolumn{2}{|l|}{ Country: Germany } \\
\hline & \multicolumn{2}{|c|}{ Inclusion criteria: SAR (+) and SPT (+) to grass pollen. No SIT previous 5 years. } \\
\hline & \multicolumn{2}{|c|}{ Total $n=34$. Active $n=17(? m)$. Placebo $=17(? m)$} \\
\hline & \multicolumn{2}{|l|}{ Age range: $18-50$ yrs. } \\
\hline & \multicolumn{2}{|c|}{ Mild-moderate asthmatics were included. } \\
\hline Interventions & \multicolumn{2}{|c|}{$\begin{array}{l}\text { Treatment: Alum-adsorbed grass allergoid (Allergovit, Allergopharma). Two strengths were used, } 1000 \\
\text { and 10,000 TU/ml. } 8 \text { injections were given as an average per patient. Maximum dose was } 6000 \mathrm{TU} \text { and } \\
\text { the mean total cumulative dose was 15,012 TU). }\end{array}$} \\
\hline Outcomes & \multicolumn{2}{|l|}{ Symptom scores. } \\
\hline & \multicolumn{2}{|l|}{ Serum slgG. } \\
\hline & \multicolumn{2}{|c|}{ Nasal lavages and cytokine measurements (IL-1b, IL-4, IL-5, IL-6 and IL-8). } \\
\hline \multicolumn{3}{|l|}{ Notes } \\
\hline \multicolumn{3}{|l|}{ Risk of bias } \\
\hline Bias & Authors' judgement & Support for judgement \\
\hline Allocation concealment? & Unclear risk & B - Unclear \\
\hline
\end{tabular}

Iliopoulos 1991

\begin{tabular}{ll}
\hline Methods & Randomised, double-blind, placebo controlled trial. \\
\hline Participants & Country: USA. \\
& Inclusion criteria: clinical symptoms of SAR and SPT $(+)$ to ragweed. \\
& Total $n=55$, active group $n=21$, placebo group $n=20,14$ patients dropped out before randomisation. \\
& No age or sex distribution reported. \\
\hline Interventions & $\begin{array}{l}\text { Treatment: short ragweed extract. Up-dosing weekly injections for } 3 \text { months, pre-seasonal. The main- } \\
\text { tenance dose was equivalent to } 1.92 \text { mcg of antigen, given bi-weekly for } 9 \text { months. Each treated patient } \\
\text { received a total dose of approx } 24 \text { mcg of antigen extract. }\end{array}$
\end{tabular}

Outcomes

Patient symptom/medication scores.

Adverse reactions. 
Iliopoulos 1991 (Continued)

Nasal challenges and intradermal skin test (early and late reactions).

Specific IgE and IgG antibodies.

\section{Notes}

\section{Risk of bias}

\begin{tabular}{lll}
\hline Bias & Authors' judgement & Support for judgement \\
\hline Allocation concealment? & Low risk & A - Adequate \\
\hline
\end{tabular}

Juniper 1985

\begin{tabular}{ll}
\hline Methods & Randomised, double-blind, placebo controlled trial. \\
\hline Participants & Country: Canada. \\
Inclusion criteria: clinical symptoms of SAR and SPT $(+)$ to ragweed. \\
Total $n=62$, active group $n=30(18 \mathrm{~m})$, placebo group $n=30(10 \mathrm{~m})$. \\
Aged from 21 to 61 yrs. \\
\hline Interventions \\
Treatment: short ragweed extract. Pre-seasonal treatment given. Up-dosing phase included 2 groups \\
Occording to sensitivity to ragweed in SPT: (a) severe sensitivity group received 10 injections (starting at \\
Duration of treatment was 2 years.
\end{tabular}

\begin{tabular}{ll}
\hline Outcomes & Patient symptom/medication scores recorded in diary cards. \\
& $\begin{array}{l}\text { Adverse events. } \\
\text { Specific IgE and IgG antibodies. }\end{array}$ \\
\hline Notes & $\begin{array}{l}\text { 2 sub-groups in year. Data from year } 2 \text { was not included for the analysis. The nurses administering the } \\
\text { injections were aware of who was receiving active treatment or placebo, although they did not partici- } \\
\text { pate in the assessment of outcomes, which was done by another investigator who was blinded. }\end{array}$
\end{tabular}

\section{Risk of bias}

\begin{tabular}{lll}
\hline Bias & Authors' judgement & Support for judgement \\
\hline Allocation concealment? & High risk & C - Inadequate \\
\hline
\end{tabular}

Jutel 2005

\begin{tabular}{|c|c|}
\hline Methods & Randomised, double-blind, placebo controlled trial. \\
\hline \multirow[t]{3}{*}{ Participants } & Country: Poland and Germany. \\
\hline & $\begin{array}{l}\text { Inclusion criteria: SAR }(+) \text { moderate-severe to grass pollen that requires medication during the previous } \\
\text { pollen season. SPT }(+) \text {, RAST-CAP }(+)>2 \text {, and CPT }(+) \text {. No SIT previous last } 3 \text { yrs. }\end{array}$ \\
\hline & Total $n=57$. Active $n=29(21 \mathrm{~m})$. Placebo $=28(16 \mathrm{~m})$ \\
\hline
\end{tabular}


Jutel 2005 (Continued)

$$
\text { Median age: } 25 \mathrm{yrs} \text {. }
$$

Mild-moderate seasonal asthmatics were included.

Interventions
treatment: a mixture of 5 recombinant grass pollen allergens. Median cumulative dose was 490 ug to-
an number of injections per participant in each group was 25.
Duration: Jan 2002 until Sep 2003.

\begin{tabular}{ll}
\hline Outcomes & Symptom/medication scores recorded by patients during the pollen season. \\
& RQLQ. \\
CPT. & Adverse events. \\
& Specific IgE, IgG1, IgG4. \\
\hline Notes & \\
\hline Risk of bias & Authors' judgement Support for judgement \\
\hline Bias & Low risk A - Adequate \\
\hline Allocation concealment? & A \\
\hline
\end{tabular}

Karmaker 1994

\begin{tabular}{ll}
\hline Methods & Randomised, double-blind, placebo controlled trial. \\
\hline Participants & Country: India. \\
& Inclusion criteria: Clinical symptoms of rhinitis $+/$ - asthma and SPT $(+)$ to cocos nucifera tree pollen. \\
& Total $n=105$, active $n=86$, placebo $n=19$. \\
& Aged 6 to 56 yrs.
\end{tabular}

Interventions

Treatment: cocos nucifera pollen extract.

Total treatment duration and dosage given were not reported.

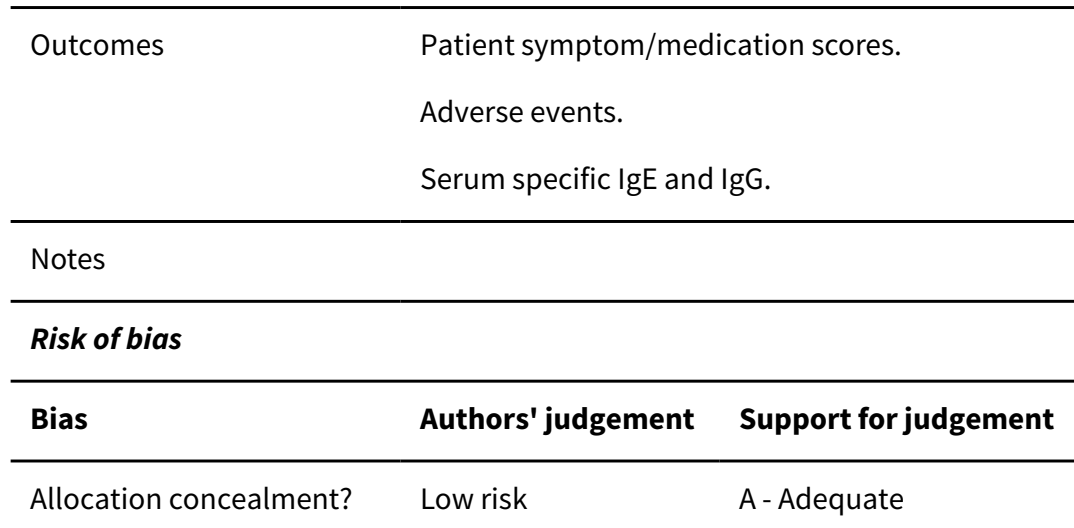


Lee 1982

\begin{tabular}{|c|c|}
\hline Methods & Randomised, double-blind, placebo controlled trial. \\
\hline Participants & $\begin{array}{l}\text { Country: USA. } \\
\text { Inclusion criteria: clinical symptoms of SAR +/- asthma and SPT }(+) \text { to mountain cedar pollen. } \\
\text { Total } n=90 \text {, active group } n=48(28 \mathrm{~m}) \text {, placebo group } n=28(17 \mathrm{~m}) \text {. } \\
\text { Age range } 18 \text { - } 50 \text { years. }\end{array}$ \\
\hline Interventions & $\begin{array}{l}\text { Treatment: mountain cedar allergenic extract. Mean number of injections 14.4-15.6 per subject. Mean } \\
\text { starting dose: } 6.99 \text { PNU in SDET (serial dilution end point titration) group and 0.16 PNU in traditional IT } \\
\text { group. Mean final dose: } 245 \text { PNU in SDET group and } 82 \text { PNU in traditional IT group. }\end{array}$ \\
\hline Outcomes & $\begin{array}{l}\text { Patient symptom/medication scores. } \\
\text { Adverse events. } \\
\text { Total serum IgE. } \\
\text { Serum allergen specific IgE. }\end{array}$ \\
\hline Notes & Study design included 3 study groups: traditional IT, SDET and placebo. \\
\hline
\end{tabular}

\section{Risk of bias}

\begin{tabular}{lll}
\hline Bias & Authors' judgement & Support for judgement \\
\hline Allocation concealment? & Low risk & A-Adequate \\
\hline
\end{tabular}

Leynadier 2001

\begin{tabular}{|c|c|}
\hline Methods & Randomised, double-blind, placebo controlled trial. \\
\hline Participants & $\begin{array}{l}\text { Country: France. } \\
\text { Inclusion criteria: SAR }(+)+/ \text { - seasonal asthma, SPT }(+) \text {, RAST }(+) \text { and nasal provocation test }(+) \text { to grass } \\
\text { pollens (orchard, meadow, rye, sweet vernal and timothy). } \\
\text { Total } n=29 \text {; active group } n=16(7 \mathrm{~m}) \text {, placebo group } n=13(7 \mathrm{~m}) . \\
\text { Aged } 18-44 \text { years. }\end{array}$ \\
\hline Interventions & $\begin{array}{l}\text { Treatment: standardised 5-grass-pollen extract adsorbed onto calcium phosphate. } 16 \text { weekly injec- } \\
\text { tions were given as induction phase and maintenance was given monthly. } \\
\text { Duration was } 1 \text { year. }\end{array}$ \\
\hline Outcomes & $\begin{array}{l}\text { Patient symptom/medication scores. } \\
\text { Adverse events. } \\
\text { Nasal provocation test. SPT responses. } \\
\text { Serum IgE and IgG4 levels. }\end{array}$ \\
\hline
\end{tabular}


Leynadier 2001 (Continued)

Notes

\section{Risk of bias}

\begin{tabular}{lll}
\hline Bias & Authors' judgement & Support for judgement \\
\hline Allocation concealment? & Low risk & A - Adequate \\
\hline
\end{tabular}

\section{Litwin 1991}

Methods Randomised, double-blind, placebo controlled trial.

\begin{tabular}{ll}
\hline Participants & Country: USA. \\
Inclusion criteria: SAR $(+)$, SPT $(+)$ and RAST $(+)$ to ragweed. \\
Total $n=39$; active group $n=20$ and placebo $n=19$. \\
Aged 21 to 50 years. \\
No sex distribution given. \\
\hline Treatment: Peptic fragment of a short ragweed pollen given weekly. Final dose achieved was approx 13 \\
\hline ug Amb a I. \\
\hline Symptom/medication score recorded in diary cards. \\
Adverse events. \\
Antigen specific IgE and IgG .
\end{tabular}

Notes

\section{Risk of bias}

\begin{tabular}{lll}
\hline Bias & Authors' judgement & Support for judgement \\
\hline Allocation concealment? & Low risk & A-Adequate \\
\hline
\end{tabular}

Meriney 1986

Methods Randomised, double-blind, placebo controlled trial.

Country: USA.
Inclusion criteria: Clinical history of SAR, intradermal $(2+)$ to ragweed pollen.
Total $n=20(9 \mathrm{~m})$, allergoid group $n=10$, placebo group $n=10$.
Aged $21-52$ yrs

Interventions Treatment: allergoid ragweed extract.

Duration of treatment was 20 weeks with 13 injections total. Max dosage 4000 PNU.

Outcomes Patient symptom scores.


Meriney 1986 (Continued)
Adverse events.
Allergen specific-IgE and IgG.
Total serum IgE.
Pollen count.

\section{Notes}

\section{Risk of bias}

\begin{tabular}{lll}
\hline Bias & Authors' judgement & Support for judgement \\
\hline Allocation concealment? & Low risk & A-Adequate \\
\hline
\end{tabular}

Metzger 1981

\begin{tabular}{ll} 
Methods & Randomised, double-blind, placebo controlled trial. \\
\hline Participants & Country: USA and England. \\
& Inclusion criteria: clinical history of SAR and SPT $(+)$ to ragweed pollen. \\
& Total $n=100 ;$ active group $n=50$, placebo group $n=50$. \\
& No sex or age distribution reported. \\
& $\begin{array}{l}\text { Treatment: glutaraldehyde-modified, tyrosine-adsorbed ragweed extract. A total of } 5 \text { weekly pre-sea- } \\
\text { sonal injections were given. Dosages 350, 1000, 3000, } 6000 \text { and } 6000 \text { PNU. }\end{array}$ \\
\hline Interventions & Patient symptom score. \\
Outcomes & $\begin{array}{l}\text { Adverse events. } \\
\text { Overall evaluation. } \\
\text { Antigen specific lgE and IgG. } \\
\text { Pollen count. }\end{array}$
\end{tabular}

\section{Notes}

\section{Risk of bias}

\begin{tabular}{lll}
\hline Bias & Authors' judgement & Support for judgement \\
\hline Allocation concealment? & Low risk & A - Adequate \\
\hline
\end{tabular}

\section{Mirone 2004}

\begin{tabular}{ll}
\hline Methods & Randomised, double-blind, placebo controlled trial. \\
\hline Participants & Country: Italy. \\
& Inclusion criteria: SAR $(+)$, SPT $(+)$ and CAP $(+)$ to Ambrosia.
\end{tabular}


Mirone 2004 (Continued)

Total $n=32$. Active $n=16(7 m)$. Placebo $=16(11 \mathrm{~m}) .13$ patients had mild-moderate seasonal asthma $(6$ in active group).

Age range: 23- $60 \mathrm{yrs}$.

Interventions

Treatment: Biologically standardised extract of Ambrosia artemisiifolia pollen absorbed onto aluminium hydroxide (ALK-Abello). 10, 100 and $1000 \mathrm{STU} / \mathrm{ml}$ (0.09, 0.9 and $9 \mathrm{ug} / \mathrm{ml}$ of the major allergen AMb a 1 ) were used.

Duration: 1 year.

Outcomes

Symptom/medication scores recorded by patients during the pollen season.

Skin challenge.

Adverse events.

Notes

\section{Risk of bias}

\begin{tabular}{lll}
\hline Bias & Authors' judgement & Support for judgement \\
\hline Allocation concealment? & Low risk & A - Adequate \\
\hline
\end{tabular}

Norman 1982

Methods Randomised, double-blind, placebo controlled trial.

\begin{tabular}{ll}
\hline Participants & Country: USA. \\
& Inclusion criteria: clinical history of SAR or mild asthma and intradermal (+) to ragweed pollen. \\
& Total $\mathrm{N}=20$, active $\mathrm{n}=10$, placebo $\mathrm{n}=10$. \\
& Aged $18-55 \mathrm{yrs}$. \\
& No sex distribution given. \\
\hline Interventions & Treatment: $1 / 20 \mathrm{w} / \mathrm{v} 50 \%$ glycerinated extract of short ragweed pollen. Ragweed allergoid and placebo \\
& given in clustered regimen, unaltered ragweed extract (allergen) given in a weekly regimen.
\end{tabular}

Outcomes Patient symptom-medication scores using daily diaries.

Adverse reactions.

Specific IgE levels and IgG antibody levels

\section{Notes}

\section{Risk of bias}

\begin{tabular}{lll}
\hline Bias & Authors' judgement & Support for judgement \\
\hline Allocation concealment? & Low risk & A - Adequate \\
\hline
\end{tabular}


Ortolani 1984

\begin{tabular}{|c|c|c|}
\hline Methods & \multicolumn{2}{|c|}{ Randomised, double-blind, placebo controlled trial. } \\
\hline \multirow[t]{4}{*}{ Participants } & \multicolumn{2}{|l|}{ Country: Italy and USA. } \\
\hline & \multicolumn{2}{|c|}{$\begin{array}{l}\text { Inclusion criteria: clinical history of rhinitis and asthma, } \mathrm{SPT}(+) \text { and } \mathrm{RAST}(+) \text { only to timothy grass } \\
\text { pollen. }\end{array}$} \\
\hline & \multicolumn{2}{|c|}{ Total $n=15 ;$ active group $n=8(4 m)$, placebo group $n=7(2 m)$. } \\
\hline & \multicolumn{2}{|l|}{ Aged $15-45$ yrs. } \\
\hline Interventions & \multicolumn{2}{|c|}{$\begin{array}{l}\text { Treatment: Aqueous lyophized extract was purified and consisted of } 33 \% \text { velvet, } 33 \% \text { sweet vernal and } \\
33 \% \text { timothy grass pollen. The average single max dosage was } 6000 \text { RAST units and the mean cumula- } \\
\text { tive dose was } 18,700 \text { RAST units. }\end{array}$} \\
\hline \multirow[t]{6}{*}{ Outcomes } & \multicolumn{2}{|c|}{ Patient symptom/ medication score recorded by diary cards. } \\
\hline & \multicolumn{2}{|l|}{ Adverse events. } \\
\hline & \multicolumn{2}{|l|}{ Nasal secretions. } \\
\hline & \multicolumn{2}{|c|}{ Specific bronchial provocation test. } \\
\hline & \multicolumn{2}{|c|}{ Antigen specific IgE and IgG (total and subclasses 1 to 4 ). } \\
\hline & \multicolumn{2}{|l|}{ Pollen count. } \\
\hline Notes & \multicolumn{2}{|c|}{10,000 RAST units $=7000 \mathrm{PNU}$} \\
\hline \multicolumn{3}{|l|}{ Risk of bias } \\
\hline Bias & Authors' judgement & Support for judgement \\
\hline Allocation concealment? & Low risk & A - Adequate \\
\hline
\end{tabular}

Ortolani 1994

\begin{tabular}{ll}
\hline Methods & Randomised, double-blind, placebo controlled trial. \\
\hline Participants & Country: Italy. \\
& Inclusion criteria: SAR $(+), S P T(+)$ and RAST $(+)$ to Parietaria judaica. \\
& Total $n=35 ;$ active group $n=18(7 \mathrm{~m})$ and placebo $n=17(7 \mathrm{~m})$. \\
& Age range 14 to 59. \\
& Some patients with seasonal asthma. \\
\hline Interventions & Treatment: aqueous extract of Parietaria judaica. Total 12 injections at weekly intervals with doses \\
& from 1 to 800 U. \\
\hline Outcomes & Symptom/medication scores recorded by patients. \\
Adverse reactions. & Nasal, conjunctival and skin reactivity was assessed. \\
Specific IgE, IgG1 and IgG4.
\end{tabular}


Ortolani 1994 (Continued)

Notes

\section{Risk of bias}

\begin{tabular}{lll}
\hline Bias & Authors' judgement & Support for judgement \\
\hline Allocation concealment? & Low risk & A - Adequate \\
\hline
\end{tabular}

\section{Paraskevopoulos 2005}

\begin{tabular}{|c|c|c|}
\hline Methods & \multicolumn{2}{|c|}{ Randomised, double-blind, placebo controlled trial. } \\
\hline \multirow[t]{3}{*}{ Participants } & \multicolumn{2}{|l|}{ Country: UK. } \\
\hline & \multicolumn{2}{|c|}{$\begin{array}{l}\text { Inclusion criteria SAR }(+) \text { inadequately controlled with standard medication. SPT }(+) \text { and RAST }(+) \text { to } \\
\text { Phleum pratense. No SIT previous } 5 \text { yrs. }\end{array}$} \\
\hline & \multicolumn{2}{|c|}{ Total $n=18$. Active group 100,000 SQ-U $n=12(7 m)$} \\
\hline Interventions & \multicolumn{2}{|c|}{$\begin{array}{l}\text { Treatment: standardised depot preparations of grass pollen extract (Alutard SQ-U Phleum pratense, } \\
\text { ALK-Abello) were given by subcutaneous injection. The up-dosing phase consisted of } 15 \text { injections over } \\
8 \text { weeks. }\end{array}$} \\
\hline Outcomes & \multicolumn{2}{|l|}{ Late skin response. } \\
\hline Notes & \multicolumn{2}{|c|}{ Alutard Phleum pratense 100,000 SQ-U (ALK-Abello) corresponds to $20 \mu \mathrm{g}$ of major allergen Phl p 5.} \\
\hline \multicolumn{3}{|l|}{ Risk of bias } \\
\hline Bias & Authors' judgement & Support for judgement \\
\hline Allocation concealment? & Low risk & A - Adequate \\
\hline
\end{tabular}

\section{Parker 1989}

\begin{tabular}{ll}
\hline Methods & Randomised, double-blind, placebo controlled trial. \\
\hline Participants & Country: USA. \\
& Inclusion criteria: SAR $(+)$ and SPT $(+)$ to mountain cedar pollen. No SIT previous 5 years. \\
& Total $n=51$. Active $n=26(13 \mathrm{~m})$. Placebo $=25(12 \mathrm{~m})$. \\
& Age range: $22-75$ yrs. \\
& No asthma data given. \\
\hline Interventions & Treatment: Mountain cedar (Juniperus ashei) extract which contains 3.18 mg of protein per ml. Up-dos- \\
& ing schedule from 0.1 ml with increments of 0.05 to 0.1 ml until the highest dose of $0.5 \mathrm{ml}$ was reached. \\
\hline Outcomes & Symptom/medication scores recorded by patients during the pollen season. \\
& Adverse events. \\
Immediate and late cutaneous response.
\end{tabular}


Parker 1989 (Continued)

Serum slgE, slgG1 and slgG4.

\section{Notes}

\section{Risk of bias}

\begin{tabular}{lll}
\hline Bias & Authors' judgement & Support for judgement \\
\hline Allocation concealment? & Unclear risk & B - Unclear \\
\hline
\end{tabular}

Pastorello 1992

\begin{tabular}{|c|c|c|}
\hline Methods & \multicolumn{2}{|c|}{ Randomised, double-blind, placebo controlled trial. } \\
\hline \multirow[t]{5}{*}{ Participants } & \multicolumn{2}{|c|}{ Country: Italy and Germany. } \\
\hline & \multicolumn{2}{|c|}{ Inclusion criteria: SAR(+), SPT (+) and RAST(+) to mixed grass pollen. } \\
\hline & \multicolumn{2}{|c|}{ Total $n=19 ;$ active group $n=10$ and placebo group $n=9 . m=7$. } \\
\hline & \multicolumn{2}{|l|}{ Age range 18 to 56 . } \\
\hline & \multicolumn{2}{|c|}{ Some patients with seasonal asthma. } \\
\hline Interventions & \multicolumn{2}{|c|}{$\begin{array}{l}\text { Treatment: grass allergoid obtain by mild formalinisation of a grass pollen extract (six grasses, Dactylis } \\
\text { glomerata, Festuca elatio, Holcus lanatus, Phleum pratense, Lolium perenne and Poa pratensis). Maxi- } \\
\text { mum concentration of } 20,000 \text { PNU. }\end{array}$} \\
\hline Outcomes & \multicolumn{2}{|c|}{ Symptoms/medication scores recorded by patients. } \\
\hline & \multicolumn{2}{|l|}{ Adverse reactions. } \\
\hline & \multicolumn{2}{|c|}{ Nasal and skin reactivity. } \\
\hline & \multicolumn{2}{|c|}{ Specific IgE, IgG1 and IgG4. } \\
\hline \multicolumn{3}{|l|}{ Notes } \\
\hline \multicolumn{3}{|l|}{ Risk of bias } \\
\hline Bias & Authors' judgement & Support for judgement \\
\hline Allocation concealment? & Low risk & A - Adequate \\
\hline
\end{tabular}

Tari 1997

\begin{tabular}{ll}
\hline Methods & Randomised, double-blind, placebo controlled trial. \\
\hline Participants & Country: Italy and Germany. \\
& Inclusion criteria: clinical history of rhinitis $+/$ - asthma, SPT $(+)$, RAST $(+)$ and nasal provocation test $(+)$ to \\
& Parietaria pollen. \\
& Total $n=40$; allergoid group $n=20(10 \mathrm{~m})$, placebo group $n=20(10 \mathrm{~m})$. \\
& Aged $13-50$ yrs.
\end{tabular}


Tari 1997 (Continued)

Asthma $\mathrm{n}=14$ in allergoid group, $\mathrm{n}=10$ in placebo group.

Interventions Treatment: Alum-adsorbed Parietaria pollen allergoid. Mean cumulative treatment dose in up-dosing phase was $1,500 \mathrm{TU}$ and in maintenance phase was 24,500 TU.

\begin{tabular}{ll}
\hline Outcomes & Patient symptom/medication scores. \\
& Adverse events. \\
& Nasal and skin reactivity. \\
& Nasal inspiratory peak flow. \\
& Total and specific IgE and IgG. \\
& \\
\hline Notes & Authors' judgement Support for judgement \\
\hline Risk of bias & Low risk A - Adequate \\
\hline Bias &
\end{tabular}

\section{Varney 1991}

\begin{tabular}{ll}
\hline Methods & Randomised, double-blind, placebo controlled trial. \\
\hline Participants & Country: England. \\
& Inclusion criteria: severe SAR to timothy grass pollen with poor drug control +/- mild seasonal asthma. \\
SPT $(+)$ and RAST $(+)$ to timothy grass pollen. \\
Total $n=40$, active group $n=21(14 \mathrm{~m})$ and placebo group $n=19(8 \mathrm{~m})$. \\
Age range 19-52 years. \\
\hline Treatment: Purified and standardised extract of Pheum pratense Alutard SQ-aluminium adsorbed for \\
slow release. Up-dosing phase: 8 weeks/15 injections; max dosage 30,000 BU. Maintenance dosage was \\
30,000 BU every 4 weeks.
\end{tabular}

Outcomes Symptom/medication scores reported by patients in diary cards (May to September).

\section{Adverse events.}

Immediate and late skin responses and immediate conjunctival response to allergen challenge.

Global assessment.

Pollen counts.
Notes $\quad 1000,000 \mathrm{SQ} / \mathrm{ml}=30,000 \mathrm{BU} / \mathrm{ml}$ Phleum pratense. During pollen season maintenance doses were re- duced by $40 \%$ in all patients. The observation period was 2 hours after each injection.

\section{Risk of bias}

\begin{tabular}{lll}
\hline Bias & Authors' judgement & Support for judgement \\
\hline Allocation concealment? & Low risk & A - Adequate \\
\hline
\end{tabular}


Walker 2001

Methods

Participants
Randomised, double-blind, placebo controlled trial.

Country: England.

Inclusion criteria: severe SAR to timothy grass pollen with poor drug control +/- mild seasonal asthma. SPT (+) and RAST (+) to timothy grass pollen.

Total $n=44$, active group $n=22(10 m)$ and placebo group $n=22(13 m)$.

Age range $22-64$ years.

Interventions Treatment: standardised, aluminium hydroxide-absorbed, depot Phleum pratense (timothy) grass pollen vaccine. Rapid up-dosing cluster regimen for 4 weeks, followed by monthly injections for 2 years. Maintenance dosage was 100,000 SQ units ( 20 mcg of allergen) every month. Patients were pretreated with an antihistamine at least 15 minutes before each visit.

\section{Outcomes}

Symptom/medication scores reported by patients in diary cards (May to September).

Adverse events.

Health-related quality of life.

Measurements of non-specific bronchial responsiveness.

Local cutaneous reactions within 1 hour were recorded.

Patients recorded any delayed (within 48 hours) local or generalised symptoms.

Intradermal allergen challenges were performed with grass pollen extract; immediate (15 mins) and late (6 hrs) skin responses were recorded.

Pollen counts.

\section{Notes}

\section{Risk of bias}

\begin{tabular}{lll}
\hline Bias & Authors' judgement & Support for judgement \\
\hline Allocation concealment? & Low risk & A - Adequate \\
\hline
\end{tabular}

\section{Zenner 1997}

\section{Methods}

Participants
Randomised, double-blind, placebo controlled trial.

Country: Germany.

Inclusion criteria: clinical history of SAR to grass and/or rye pollen. SPT (+) to grass (Dactylis glomerata, Lolium perenne, Avena elatior, Phleum pratense, Poa pratensis, and Festuca pratensis) and rye, Secale cereale.

Total $n=87$; active group $n=45(30 m)$ and placebo $n=42(29 m)$.

Age range 16 to 53 . 
Zenner 1997 (Continued)

Interventions

Treatment: tree pollen allergen extract of grass (Dactylis glomerata, Lolium perenne, Avena elatior, Phleum pratense, Poa pratensis, and Festuca pratensis) and rye (Secale cereale) for 7 weeks before the beginning of the grass-pollen season. Concentrations of 3, 10, 30, 100, 300, 600 and $1000 \mathrm{SE} / \mathrm{ml}$.
Symptom/medication scores recorded by patients.

Nasal, conjunctival and bronchial assessments.

Adverse reactions.

Specific IgE and IgG4.

\section{Notes}

\section{Risk of bias}

\begin{tabular}{lll}
\hline Bias & Authors' judgement & Support for judgement \\
\hline Allocation concealment? & Low risk & A - Adequate \\
\hline
\end{tabular}

$\mathrm{Ag}=$ antigen

$\mathrm{AU}=$ allergy unit

AUeq = allergy units equivalent

$\mathrm{BGP}=$ Bermuda grass pollen

$\mathrm{BPT}=$ bronchial provocation test

$\mathrm{BU}=$ biologic unit

$\mathrm{CPT}=$ conjunctival provocation test

GOID = unfractionated allergoid

HMW-GOID = high-molecular-weight formalinised allergoid

Ig = immunoglobulin

$\mathrm{IR}=$ index of reactivity

$\mathrm{IT}=$ immunotherapy

IU = international unit

$\mathrm{MPL}=$ monophosphoryl lipid $\mathrm{A}$

$\mathrm{PNU}=$ protein nitrogen unit

RAST = radioallergosorbent test

SAR = seasonal allergic rhinitis

SDET = serial dilution end point titration

$\mathrm{SE}=$ specific units

$\mathrm{SIT}=$ allergen-specific immunotherapy

$\mathrm{SPT}=$ skin prick test

$\mathrm{SQ}=$ standard quality

SQ-U = standard quality units

$\mathrm{TE}=$ therapeutische einheiten (therapeutic units)

$\mathrm{TU}=$ [not specified by author]

VAS = visual analogue scale

Characteristics of excluded studies [ordered by study ID]

\begin{tabular}{ll}
\hline Study & Reason for exclusion \\
\hline Aabel 2000 & Other route of immunotherapy (oral tablets). \\
\hline Adelroth 1999 & No standardised allergen extracts used. \\
\hline Adelroth 2000 & No standardised allergen extracts used. \\
\hline
\end{tabular}




\begin{tabular}{|c|c|}
\hline Study & Reason for exclusion \\
\hline Ancill 1990 & Not a specific immunotherapy study. \\
\hline Andre 2000 & Other route of immunotherapy (sublingual tablets). \\
\hline Astarita 1996 & Single or low dose used (intradermal). \\
\hline Bacal 1978 & Not a double-blind study (single). \\
\hline Barrett 2000 & Not a specific immunotherapy study. \\
\hline Berkovitz 2005 & Not allergen extracts used. \\
\hline Bernstein 1976 & Some patients had previous immunotherapy. \\
\hline Berstein 2001 & Not a specific immunotherapy study. \\
\hline Bochenska 2003 & Not a specific immunotherapy study. \\
\hline Bodtger 2003 & Data included in another paper (Bodtger 2002). \\
\hline Bolhaar 2004 & Not a seasonal allergic rhinitis study (food allergy syndrome study). \\
\hline Bonifazi 1991 & Not a placebo controlled study. \\
\hline Boznanski 1996 & Not a double-blind placebo controlled study. \\
\hline Brown 1964 & Not a randomised controlled trial. \\
\hline Bruce 1997 & Patients were asthmatics, not rhinitics. \\
\hline Brunet 1992b & Data included in another paper (Brunet 1992). \\
\hline Bruno 1986 & Not a double-blind randomised placebo controlled study. \\
\hline Caffarelli 2000 & Other route of immunotherapy (oral). \\
\hline Calderon 2003 & Data included in another paper (Frew 2006). \\
\hline Cantani 1984 & Not a placebo controlled study. \\
\hline Caramia 1996 & Not a double-blind placebo controlled study. \\
\hline Charpin 1985 & Not allergen extracts used. \\
\hline Chyrek-Borowska 1995 & Not a seasonal allergic rhinitis study (house dust mite allergy included). \\
\hline Cirla 1996 & Other route of immunotherapy (intranasal). \\
\hline Cockcroft 1977 & Low dose used (only 4 injections). \\
\hline Connell 1967 & Not a double-blind placebo controlled study. \\
\hline Creticos 1996 & Patients were asthmatics, not rhinitics. \\
\hline Creticos 2003 & Not a placebo controlled study. \\
\hline
\end{tabular}




\begin{tabular}{|c|c|}
\hline Study & Reason for exclusion \\
\hline Crimi 2001 & Other outcomes investigated. Data included in another paper (Polosa 2003). \\
\hline D'Amato 1996 & Not a placebo controlled study. \\
\hline Demoly 2002 & Peptide immunotherapy used. \\
\hline Di Stanislao 1997 & Single injection of low dose used. \\
\hline Dokic 1996 & Not a double-blind placebo controlled study. \\
\hline Donat 1981 & Not a randomised study. \\
\hline Donovan 1996 & Not a placebo controlled study. \\
\hline Dorward 1984 & Not a placebo controlled study. \\
\hline Durham 1991 & A review article. \\
\hline Durham 1996 & Other outcomes investigated. \\
\hline Durham 1999 & Withdrawal of treatment study. \\
\hline Durham 1999a & Other outcomes investigated. \\
\hline Dykewicz 1998 & Not a double-blind randomised placebo controlled study. \\
\hline Egger 1997 & Other outcome investigated. \\
\hline Eng 2006 & Follow-up study after immunotherapy discontinuation. \\
\hline Eriksson 1979 & Not a placebo controlled study. \\
\hline Fal 2002 & Not a placebo controlled study. \\
\hline Fell 1990 & Single injection used. \\
\hline Fontana 1966 & No standardised allergen extracts used. \\
\hline Frankland 1954 & Not a double-blind randomised placebo controlled study. \\
\hline Frankland 1963 & Not a double-blind randomised placebo controlled study. \\
\hline Franklin 1967 & Not a placebo controlled study. \\
\hline Frostad 1980 & Not a double-blind randomised placebo controlled study. \\
\hline Frostad 1983 & Not a placebo controlled study. \\
\hline Furin 1991 & Not a placebo controlled study. \\
\hline Gabriel 1977 & Not a seasonal allergic rhinitis study (perennial rhinitis study). \\
\hline Galvain 1999 & Review article. \\
\hline Garcia Gonzalez 2002 & Not a seasonal allergic rhinitis study (food allergy syndrome study). \\
\hline
\end{tabular}




\begin{tabular}{|c|c|}
\hline Study & Reason for exclusion \\
\hline Garcia-Selles 2003 & Not a placebo controlled study. \\
\hline Gehlhar 1998 & Not a placebo controlled study. \\
\hline Gietkiewicz 2001 & Not a placebo controlled study. \\
\hline Giovannini 2005 & Not a placebo controlled study. \\
\hline Girard 1988 & Not a specific immunotherapy study. \\
\hline Gonzalez 2002 & Not a placebo controlled study. \\
\hline Goor 1971 & Not a double-blind randomised placebo controlled study. \\
\hline Gordon 1972 & Not a placebo controlled study. \\
\hline Grammer 1985 & Not a double-blind randomised placebo controlled study. \\
\hline Guardia 2004 & Not a placebo controlled study. \\
\hline Haahtela 1984 & Not a double-blind study (open). \\
\hline Hauser 2003 & Not a specific immunotherapy study. \\
\hline Hayashi 1998 & Other outcomes investigated. \\
\hline Hendrix 1980 & Not a placebo controlled study. \\
\hline Hill 1982 & Patients were asthmatics, not rhinitics. \\
\hline Hofman 1997a & Not a placebo controlled study. \\
\hline Hofman 1997b & Not a placebo controlled study. \\
\hline Horak 1980 & Not a double-blind randomised placebo controlled study. \\
\hline Ipsen 1988 & Not a double-blind randomised placebo controlled study. \\
\hline Ito 1996 & Not a double-blind placebo controlled study. \\
\hline Johansson 1974 & Not a placebo controlled study. \\
\hline Juniper 1986 & Not a double-blind placebo controlled study. \\
\hline Kakinoki 2000 & Not a placebo controlled study. \\
\hline Karlsson 1986 & Not a seasonal allergic rhinitis study (Cladosporium herbarum allergy study). \\
\hline Kasatkin 1976 & Not a specific immunotherapy study. \\
\hline Kemker 1999 & Survey study. \\
\hline Kerr 1963 & Not a randomised study. \\
\hline Kerr 1964 & Not a double-blind placebo controlled study. \\
\hline
\end{tabular}




\begin{tabular}{|c|c|}
\hline Study & Reason for exclusion \\
\hline Keskin 2004 & Not a double-blind study (open). \\
\hline Keskin 2005 & Other outcomes investigated. \\
\hline Kjellman 1980 & Not a double-blind placebo controlled study. \\
\hline Kleine-Tebbe 2005 & Other route of immunotherapy (oral tablets). \\
\hline Kleine-Tebbe 2006 & Other route of immunotherapy (oral tablets). \\
\hline Kleinjans 2004 & Not a double-blind placebo controlled study. \\
\hline Klimek 1999a & Not a placebo controlled study. \\
\hline Klimek 1999b & Not a placebo controlled study. \\
\hline Klimek 2005 & Not a placebo controlled study. \\
\hline Kuhn 1983 & Not a placebo controlled study. \\
\hline Kuhn 1985 & Not a double-blind randomised placebo controlled study. \\
\hline Lavigne 2002 & Not allergen extracts used. \\
\hline Leiferman 1975 & Not a specific immunotherapy study. \\
\hline Levy 1971 & Not a double-blind randomised placebo controlled study and previous immunotherapy was given. \\
\hline Li 1990 & Not a specific immunotherapy study. \\
\hline Lichtenstein 1968 & Not a randomised controlled trial. \\
\hline Lichtenstein 1971 & Not a double-blind study. \\
\hline Lichtenstein 1973 & Not a double-blind study. \\
\hline Lindsay-Miller 1971 & Not a double-blind randomised placebo controlled study. \\
\hline Lombardi 2001 & Other route of immunotherapy (oral tablets). \\
\hline Lowell 1965 & Not a double-blind randomised placebo controlled study. \\
\hline Machiels 1990 & Not a specific immunotherapy study. \\
\hline Malling 1999 & Patients were asthmatics, not rhinitics. \\
\hline Manger 1984 & Not a double-blind randomised placebo controlled study. \\
\hline Martin Munoz 1996 & Patients were asthmatics, not rhinitics. \\
\hline Mastruzzo 2002 & Other outcome investigated. \\
\hline McAllen 1969 & Not a randomised study. \\
\hline Mewes 1999 & Not a placebo controlled study. \\
\hline
\end{tabular}




\begin{tabular}{|c|c|}
\hline Study & Reason for exclusion \\
\hline Miller 1974 & Insufficient data available for analysis. \\
\hline Miller 1976 & Not a double-blind randomised placebo controlled study. \\
\hline Mitchell 1971 & Not a randomised study. \\
\hline Moller 1989 & Not a seasonal allergic rhinitis study (food hypersensitivity study). \\
\hline Moller 2002 & Not a double-blind placebo controlled study. \\
\hline Mosbech 1987 & Other route of immunotherapy (oral tablets). \\
\hline Mosbech 1988 & Other route of immunotherapy (oral tablets). \\
\hline Moss 1987 & Not a placebo controlled study. \\
\hline Moverare 1998 & Other outcomes investigated. \\
\hline Moverare 2000 & Not a placebo controlled study. \\
\hline Muhlethaler 1990 & Not a placebo controlled study. \\
\hline Munoz Lejarazu 1993 & Not a placebo controlled study. \\
\hline Naclerio 1997 & Withdrawal of treatment study. \\
\hline Nakai 2002 & Not a placebo controlled study. \\
\hline Nakano 2002 & Not a placebo controlled study. \\
\hline Negro 1999 & Not a double-blind placebo controlled study. \\
\hline Nelson 1976 & Not a placebo controlled study. \\
\hline Niederberger 2004 & Other outcomes investigated. \\
\hline Nielsen 1996 & Not a specific immunotherapy study. \\
\hline Nolte 1999 & Review article. \\
\hline Norman 1968 & Not a double-blind randomised placebo controlled study. \\
\hline Norman 1969 & Review article. \\
\hline Norman 1971 & Previous immunotherapy was given. \\
\hline Norman 1972 & Compares two different immunotherapy preparations. \\
\hline Norman 1981 & Not a double-blind randomised placebo controlled study. Long term efficacy study. \\
\hline Norman 1984 & Not a specific immunotherapy study. \\
\hline Norman 1990b & Not a double-blind randomised placebo controlled study. \\
\hline Nouri 2005 & Other outcomes investigated. \\
\hline
\end{tabular}




\begin{tabular}{|c|c|}
\hline Study & Reason for exclusion \\
\hline Nouri-Aria 2004a & Other outcomes investigated. \\
\hline Nouri-Aria 2004b & Other outcomes investigated. \\
\hline Nowak-Wegrzyn 2004 & Not a seasonal allergic rhinitis study (food allergy syndrome study). \\
\hline Ohashi 1997 & Not a specific immunotherapy study. \\
\hline Olsen 1995 & Not a placebo controlled study. \\
\hline Osterballe 1980 & Not a placebo controlled study. \\
\hline Osterballe 1982 & Not a placebo controlled study. \\
\hline Osterballe $1982 a$ & Not a placebo controlled study. \\
\hline Osterballe 1982b & Not a placebo controlled study. \\
\hline Osterballe $1982 \mathrm{c}$ & Not a placebo controlled study. \\
\hline Osterballe $1982 d$ & Not a placebo controlled study. \\
\hline Osterballe $1982 \mathrm{e}$ & Not a placebo controlled study. \\
\hline Osterballe 1983 & Not a placebo controlled study. \\
\hline Parr 1976 & Not a specific immunotherapy study. \\
\hline Pastorello 1987 & Not a seasonal rhinitis study. \\
\hline Pastorello 1988 & Data included in another paper (Pastorello 1992). \\
\hline Pence 1976 & Some patients had previous immunotherapy. \\
\hline Peng 1992 & Not a placebo controlled study. \\
\hline Pereira 2003 & Not a specific immunotherapy study. \\
\hline Petersen 1988 & Not a placebo controlled study. \\
\hline Pilette 2003 & Other outcomes investigated. \\
\hline Polosa 2003 & Other outcomes investigated. \\
\hline Pronk-Admiraal 2001 & Other outcome investigated. \\
\hline Radcliffe 1996 & Not a seasonal allergic rhinitis study (perennial allergens). \\
\hline Radcliffe 2003 & Not a seasonal allergic rhinitis study (perennial allergens). \\
\hline Rajakulasingam 1997 & Not a specific immunotherapy study. \\
\hline Rak 1988 & Not a placebo controlled study. \\
\hline Rak 1990 & Not a double-blind placebo controlled study. \\
\hline
\end{tabular}




\begin{tabular}{|c|c|}
\hline Study & Reason for exclusion \\
\hline Rak 2001 & Not a placebo controlled study. \\
\hline Rasp 1999 & Not a double-blind randomised placebo controlled study. \\
\hline Ricca 1997 & Not a placebo controlled study. \\
\hline Roberts 2006 & Immunotherapy in asthma. \\
\hline Rogala 2004 & Not a placebo controlled study. \\
\hline Rover 2002 & Other outcomes investigated. \\
\hline Rozniecka 1995a & Other outcomes investigated. \\
\hline Rozniecka 1995b & Not a double-blind randomised placebo controlled study. \\
\hline Ruiz 2001 & Not a double-blind placebo controlled study. \\
\hline Sandstrom 2001 & Not a specific immunotherapy study. \\
\hline Scordamaglia 1992 & Not a specific immunotherapy study. \\
\hline Simon 1990a & Not a specific immunotherapy study. \\
\hline Simon 1990b & Not a specific immunotherapy study. \\
\hline Simons 2003 & Other outcomes investigated. \\
\hline Sin 1996 & Not a seasonal allergic rhinitis study (perennials included). \\
\hline Skoda-Turk 1980 & Not a double-blind randomised placebo controlled study. \\
\hline Sobel 1966 & Not a double-blind placebo controlled study. \\
\hline Soyogul 2005 & Other outcomes investigated. \\
\hline Spiegelman 1967 & Not a double-blind placebo controlled study. \\
\hline Stuck 2001 & Other outcomes investigated. \\
\hline Stuck 2004 & Other outcomes investigated. \\
\hline Sykora 2004 & Not a double-blind study (single). \\
\hline Symington 1977 & Not a placebo controlled study. \\
\hline Taudorf 1983 & Other route of immunotherapy (oral tablets). \\
\hline Te Pas 2004 & Other route of immunotherapy (oral). \\
\hline Troise 2000 & Single dose used. Perennial allergens used. \\
\hline Tulic 2004 & Not allergen extracts used. \\
\hline Turkeltaub 1990 & Not a placebo controlled study. \\
\hline
\end{tabular}




\begin{tabular}{|c|c|}
\hline Study & Reason for exclusion \\
\hline Vaishnav 2005 & Not whole allergen extract used. \\
\hline Valovirta 1999 & Not a placebo controlled study. \\
\hline van Adelsberg 2003 & Not a specific immunotherapy study. \\
\hline Van Metre 1980a & Rinkel method used. \\
\hline Van Metre 1980b & Rinkel method used. \\
\hline van Metre 1982 & Not a placebo controlled study. \\
\hline Vanselow 1966 & Not a specific immunotherapy study. \\
\hline Varney 1992 & Not a specific immunotherapy study. \\
\hline Varney 1993 & Other outcomes investigated. \\
\hline Verstraeten 1987 & Not a double-blind placebo controlled study. \\
\hline Vittorio 1996 & Not a placebo controlled study. \\
\hline Wachholz 2002 & Other outcomes investigated. \\
\hline Wahn 2003 & Not a specific immunotherapy study. \\
\hline Walker 1995 & Not a double-blind study (open and follow-up study). \\
\hline Walker 2003 & Withdrawal of treatment study. \\
\hline Watanabe 2003 & Other outcomes investigated. \\
\hline Weyer 1981a & Two different immunotherapy preparations were used. \\
\hline Weyer 1981b & Two different immunotherapy preparations were used. \\
\hline Weyer 1990 & Patients had previous immunotherapy. \\
\hline Wihl 1988 & Not a placebo controlled study. \\
\hline Wilcock 2005 & Other outcomes investigated. \\
\hline Williams 2001 & Other route of immunotherapy (nasal). \\
\hline Williams 2002 & Data included in another paper (Frank 2001). \\
\hline Wilson 2001a & Other outcomes investigated. \\
\hline Wilson 2001b & Other outcomes investigated. \\
\hline Winther 2000a & Not a placebo controlled study. \\
\hline Winther 2000b & Not a placebo controlled study. \\
\hline Wuthrich 1968 & Not a double-blind randomised placebo controlled study. \\
\hline
\end{tabular}




\begin{tabular}{ll}
\hline Study & Reason for exclusion \\
\hline Wuthrich 1977 & Not a double-blind randomised placebo controlled study. \\
\hline Wuthrich 1980 & Other outcomes investigated. \\
\hline Yariktas 2002 & Not a specific immunotherapy study. \\
\hline
\end{tabular}

\section{Characteristics of ongoing studies [ordered by study ID]}

Rajakulasingam 2006

Trial name or title

Study for evaluation of safety and efficacy of a pre-seasonal immunotherapy with an allergoid preparation of an extract of a 6 grass pollen mixture in patients with a clinically relevant grass pollen sensitivity.

\section{Methods}

\begin{tabular}{ll}
\hline Participants & $15-25$ patients with rhinoconjunctivitis, otherwise healthy. \\
\hline Interventions & {$[$ A] Allergoid preparation of 6 grass pollen mixture } \\
& {$[B]$ Placebo sample group }
\end{tabular}

\begin{tabular}{ll}
\hline Outcomes & $\begin{array}{l}\text { Comparison of symptom and medication scores between treatment and placebo group. } \\
\text { Changes in score of Rhinoconjunctivitis Quality of Life, documented by patient. } \\
\text { Changes in patient assessed general well-being and allergic symptom visual anologue scales. }\end{array}$ \\
\hline Starting date & 1st January 2002 \\
\hline Contact information & $\begin{array}{l}\text { K Rajakulasingam } \\
\text { Department of Respiratory Medicine, Homerton University Hospital NHS Trust, Homerton Row, } \\
\text { London, E9 6SR, UK. } \\
\text { Tel: }+442085107030 . \\
\text { Fax: }+442085107687\end{array}$ \\
\hline
\end{tabular}

\section{DATA AND ANALYSES}

\section{Comparison 1. Active versus placebo}

\begin{tabular}{llllll}
\hline Outcome or subgroup title & $\begin{array}{l}\text { No. of } \\
\text { studies }\end{array}$ & $\begin{array}{l}\text { No. of } \\
\text { partici- } \\
\text { pants }\end{array}$ & Statistical method & Effect size \\
\hline 1 Symptom score & 15 & 1063 & Std. Mean Difference (IV, Random, 95\% Cl) & $-0.73[-0.97,-0.50]$ \\
\hline 2 Medication score & 13 & 963 & Std. Mean Difference (IV, Random, 95\% Cl) & $-0.57[-0.82,-0.33]$ \\
\hline 3 Symptom and medication & 8 & 617 & Std. Mean Difference (IV, Random, 95\% Cl) & $-0.48[-0.67,-0.29]$ \\
\hline 4 Nasal symptom & 8 & 633 & Std. Mean Difference (IV, Random, 95\% Cl) & $-1.59[-2.29,-0.89]$ \\
\hline \hline
\end{tabular}

Allergen injection immunotherapy for seasonal allergic rhinitis (Review) 


\begin{tabular}{lllll}
\hline Outcome or subgroup title & $\begin{array}{l}\text { No. of } \\
\text { studies }\end{array}$ & $\begin{array}{l}\text { No. of } \\
\text { partici- } \\
\text { pants }\end{array}$ & Statistical method & Effect size \\
\hline 5 Bronchial symptom & 5 & 429 & Std. Mean Difference (IV, Random, 95\% Cl) & $-0.59[-1.06,-0.11]$ \\
\hline 6 Ocular symptom & 3 & 345 & Std. Mean Difference (IV, Random, 95\% Cl) & $-1.80[-3.28,-0.31]$ \\
\hline 7 IgG & 4 & 191 & Std. Mean Difference (IV, Random, 95\% Cl) & $1.90[0.88,2.93]$ \\
\hline 8 IgG-4 & 5 & 404 & Std. Mean Difference (IV, Random, 95\% Cl) & $0.79[0.49,1.08]$ \\
\hline $\begin{array}{l}\text { 9 Rhinoconjunctivitis Quali- } \\
\text { ty of Life score }\end{array}$ & 5 & 571 & Std. Mean Difference (IV, Random, 95\% Cl) & $-0.52[-0.69,-0.34]$ \\
\hline
\end{tabular}

Analysis 1.1. Comparison 1 Active versus placebo, Outcome 1 Symptom score.

\begin{tabular}{|c|c|c|c|c|c|c|c|}
\hline \multirow[t]{2}{*}{ Study or subgroup } & \multicolumn{2}{|c|}{ Treatment } & \multicolumn{2}{|c|}{ Control } & \multirow{2}{*}{$\begin{array}{c}\text { Std. Mean Difference } \\
\text { Random, } 95 \% \mathrm{Cl}\end{array}$} & \multirow[t]{2}{*}{ Weight } & \multirow{2}{*}{$\begin{array}{c}\text { Std. Mean Difference } \\
\text { Random, } 95 \% \mathrm{Cl}\end{array}$} \\
\hline & $\mathbf{N}$ & $\operatorname{Mean}(S D)$ & $\mathbf{N}$ & Mean(SD) & & & \\
\hline Balda 1998 & 49 & $6.6(10.4)$ & 56 & $9.1(8.2)$ & $\rightarrow$ & $9.33 \%$ & $-0.27[-0.65,0.12]$ \\
\hline Bodtger 2002 & 16 & $2.2(1)$ & 17 & $3.3(1.4)$ & $\longrightarrow$ & $5.75 \%$ & $-0.88[-1.6,-0.16]$ \\
\hline Bousquet 1990 & 20 & $63.6(32.5)$ & 18 & $108.6(33.2)$ & 1 & $5.81 \%$ & $-1.34[-2.05,-0.63]$ \\
\hline Brewczynski 1999 & 10 & $59.5(32.6)$ & 8 & $122.4(85.1)$ & & $3.84 \%$ & $-0.98[-1.97,0.02]$ \\
\hline Corrigan 2005 & 77 & $\begin{array}{r}166.5 \\
(114.9)\end{array}$ & 77 & $218(135.4)$ & + & $10.12 \%$ & $-0.41[-0.73,-0.09]$ \\
\hline Drachenberg 2001 & 74 & $0.8(0.4)$ & 50 & $1(0.4)$ & $\rightarrow$ & $9.59 \%$ & $-0.46[-0.83,-0.1]$ \\
\hline Ferrer 2005 & 22 & $0.4(0.3)$ & 20 & $0.8(0.5)$ & $\longrightarrow$ & $6.55 \%$ & $-0.81[-1.44,-0.17]$ \\
\hline Frew 2006 & 187 & $3.3(2.4)$ & 89 & $4.6(2.9)$ & + & $10.85 \%$ & $-0.49[-0.75,-0.24]$ \\
\hline Jutel 2005 & 29 & $3.9(3.3)$ & 28 & $5.8(3.4)$ & 4 & $7.62 \%$ & $-0.55[-1.08,-0.02]$ \\
\hline Meriney 1986 & 10 & $3.5(3)$ & 10 & $8.4(4.2)$ & & $3.91 \%$ & $-1.29[-2.27,-0.3]$ \\
\hline Ortolani 1984 & 8 & $2(0.6)$ & 7 & $5.9(1.6)$ & & $1.78 \%$ & $-3.06[-4.69,-1.43]$ \\
\hline Varney 1991 & 19 & $1531(1875)$ & 16 & $2230(856)$ & $\longrightarrow$ & $6.14 \%$ & $-0.46[-1.13,0.22]$ \\
\hline Walker 2001 & 17 & $\begin{array}{r}-1212 \\
(2632)\end{array}$ & 13 & $-115(1159)$ & $\longrightarrow$ & $5.61 \%$ & $-0.5[-1.24,0.23]$ \\
\hline Zenner 1997 & 41 & $82.2(64.4)$ & 40 & $116(83.7)$ & $\longrightarrow$ & $8.65 \%$ & $-0.45[-0.89,-0.01]$ \\
\hline 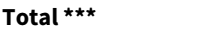 & 597 & & 466 & & $>$ & $100 \%$ & $-0.73[-0.97,-0.5]$ \\
\hline \multicolumn{8}{|c|}{ Heterogeneity: $\mathrm{Tau}^{2}=0.12 ; \mathrm{Chi}^{2}=38.05, \mathrm{df}=14(\mathrm{P}=0) ; \mathrm{I}^{2}=63.21 \%$} \\
\hline \multicolumn{3}{|c|}{ Test for overall effect: $Z=6.1(P<0.0001)$} & & & & & \\
\hline
\end{tabular}

Analysis 1.2. Comparison 1 Active versus placebo, Outcome 2 Medication score.

\begin{tabular}{|c|c|c|c|c|c|c|c|}
\hline \multirow[t]{2}{*}{ Study or subgroup } & \multicolumn{2}{|c|}{ Treatment } & \multicolumn{2}{|c|}{ Control } & \multirow{2}{*}{$\begin{array}{c}\text { Std. Mean Difference } \\
\text { Random, } 95 \% \mathrm{Cl}\end{array}$} & \multirow[t]{2}{*}{ Weight } & \multirow{2}{*}{$\begin{array}{c}\text { Std. Mean Difference } \\
\text { Random, } 95 \% \mathrm{Cl}\end{array}$} \\
\hline & $\mathbf{N}$ & Mean(SD) & $\mathbf{N}$ & $\operatorname{Mean}(S D)$ & & & \\
\hline Balda 1998 & 49 & $9(16)$ & 56 & $13.6(19.7)$ & $\rightarrow$ & $10.47 \%$ & $-0.25[-0.64,0.13]$ \\
\hline Bodtger 2002 & 17 & $9.9(7)$ & 17 & $14.5(8.5)$ & $\longrightarrow$ & $6.74 \%$ & $-0.58[-1.26,0.11]$ \\
\hline Bousquet 1990 & 20 & $38.6(37.6)$ & 18 & $66.4(51.7)$ & $\longrightarrow$ & $7.1 \%$ & $-0.61[-1.26,0.05]$ \\
\hline Brewczynski 1999 & 10 & $17.2(10.4)$ & 8 & $36.8(35.5)$ & 1 & $4.45 \%$ & $-0.76[-1.73,0.22]$ \\
\hline
\end{tabular}




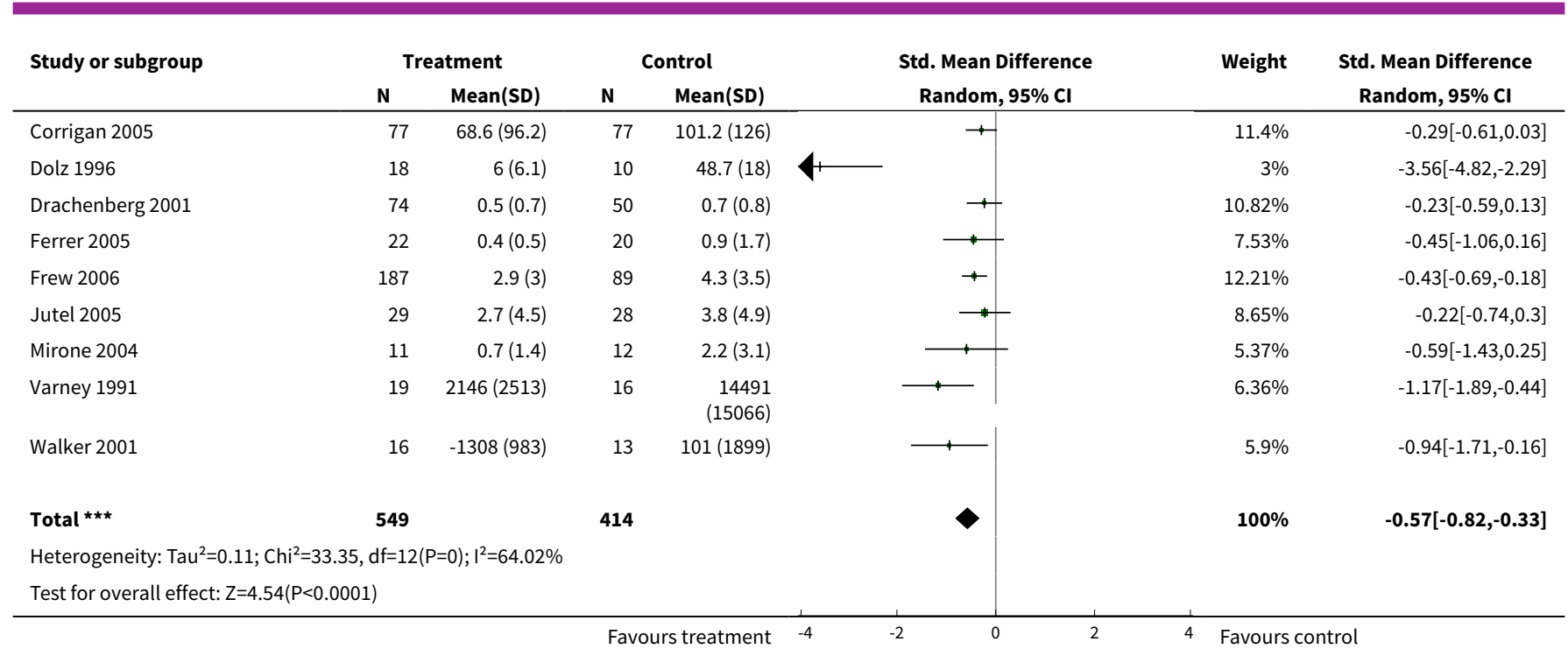

Analysis 1.3. Comparison 1 Active versus placebo, Outcome 3 Symptom and medication.

\begin{tabular}{|c|c|c|c|c|c|c|c|}
\hline \multirow[t]{2}{*}{ Study or subgroup } & \multicolumn{2}{|c|}{ Treatment } & \multicolumn{2}{|c|}{ Control } & \multirow{2}{*}{$\begin{array}{c}\text { Std. Mean Difference } \\
\text { Random, } 95 \% \mathrm{Cl}\end{array}$} & \multirow[t]{2}{*}{ Weight } & \multirow{2}{*}{$\begin{array}{c}\text { Std. Mean Difference } \\
\text { Random, } 95 \% \mathrm{Cl}\end{array}$} \\
\hline & $\mathbf{N}$ & Mean(SD) & $\mathbf{N}$ & Mean(SD) & & & \\
\hline Balda 1998 & 49 & $201.4(97.4)$ & 56 & $221.3(87.5)$ & $\rightarrow$ & $17.18 \%$ & $-0.21[-0.6,0.17]$ \\
\hline Corrigan 2005 & 77 & $235.1(172)$ & 77 & $\begin{array}{r}319.2 \\
(201.7)\end{array}$ & $\rightarrow$ & $21.94 \%$ & $-0.45[-0.77,-0.13]$ \\
\hline Drachenberg 2001 & 74 & $0.7(0.5)$ & 50 & $0.8(0.5)$ & $\rightarrow$ & $18.68 \%$ & $-0.38[-0.74,-0.01]$ \\
\hline Ferrer 2005 & 22 & $0.6(0.4)$ & 20 & $1.3(1)$ & $\longrightarrow$ & $7.77 \%$ & $-0.84[-1.47,-0.21]$ \\
\hline Ortolani 1994 & 18 & $12.9(3.6)$ & 17 & $17.8(4.9)$ & $\longrightarrow$ & $6.23 \%$ & $-1.12[-1.84,-0.4]$ \\
\hline Pastorello 1992 & 10 & $1.7(0.6)$ & 9 & $3.2(1.5)$ & - & $3.39 \%$ & $-1.22[-2.22,-0.22]$ \\
\hline Zenner 1997 & 41 & $153.8(63.5)$ & 40 & $174.5(59)$ & $\rightarrow$ & $14.17 \%$ & $-0.33[-0.77,0.1]$ \\
\hline 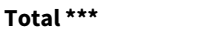 & 320 & & 297 & & 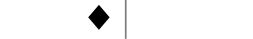 & $100 \%$ & $-0.48[-0.67,-0.29]$ \\
\hline \multicolumn{8}{|c|}{ Heterogeneity: $\mathrm{Tau}^{2}=0.02 ; \mathrm{Chi}^{2}=8.98, \mathrm{df}=7(\mathrm{P}=0.25) ; \mathrm{I}^{2}=22.05 \%$} \\
\hline
\end{tabular}

Analysis 1.4. Comparison 1 Active versus placebo, Outcome 4 Nasal symptom.

\begin{tabular}{|c|c|c|c|c|c|c|c|}
\hline \multirow[t]{2}{*}{ Study or subgroup } & \multicolumn{2}{|c|}{ Treatment } & \multicolumn{2}{|c|}{ Control } & \multirow{2}{*}{$\begin{array}{c}\text { Std. Mean Difference } \\
\text { Random, } 95 \% \mathrm{Cl}\end{array}$} & \multirow[t]{2}{*}{ Weight } & \multirow{2}{*}{$\begin{array}{c}\text { Std. Mean Difference } \\
\text { Random, } 95 \% \mathrm{Cl}\end{array}$} \\
\hline & $\mathbf{N}$ & $\operatorname{Mean}(\mathrm{SD})$ & $\mathbf{N}$ & Mean(SD) & & & \\
\hline Balda 1998 & 49 & $2.8(4.3)$ & 56 & $4.4(4.4)$ & + & $14.95 \%$ & $-0.37[-0.76,0.02]$ \\
\hline Bousquet 1987b & 39 & $61(17.9)$ & 19 & $109(16.8)$ & $\leftarrow$ & $13.29 \%$ & $-2.7[-3.45,-1.95]$ \\
\hline D'Amato 1995 & 9 & $24.6(18.4)$ & 11 & $78.5(5.6)$ & $\longrightarrow$ & $8.44 \%$ & $-3.98[-5.62,-2.35]$ \\
\hline Dolz 1996 & 18 & $0.1(0.2)$ & 10 & $1.4(0.2)$ & & $6.82 \%$ & $-6.59[-8.6,-4.57]$ \\
\hline Ferrer 2005 & 22 & $0.6(0.4)$ & 20 & $0.9(0.6)$ & + & $13.93 \%$ & $-0.68[-1.31,-0.06]$ \\
\hline Mirone 2004 & 11 & $4(3.3)$ & 12 & $8.3(4.2)$ & $\rightarrow$ & $12.51 \%$ & $-1.09[-1.98,-0.2]$ \\
\hline Zenner 1997 & 41 & $44.5(32.2)$ & 40 & $63.3(38.3)$ & + & $14.74 \%$ & $-0.53[-0.97,-0.08]$ \\
\hline
\end{tabular}




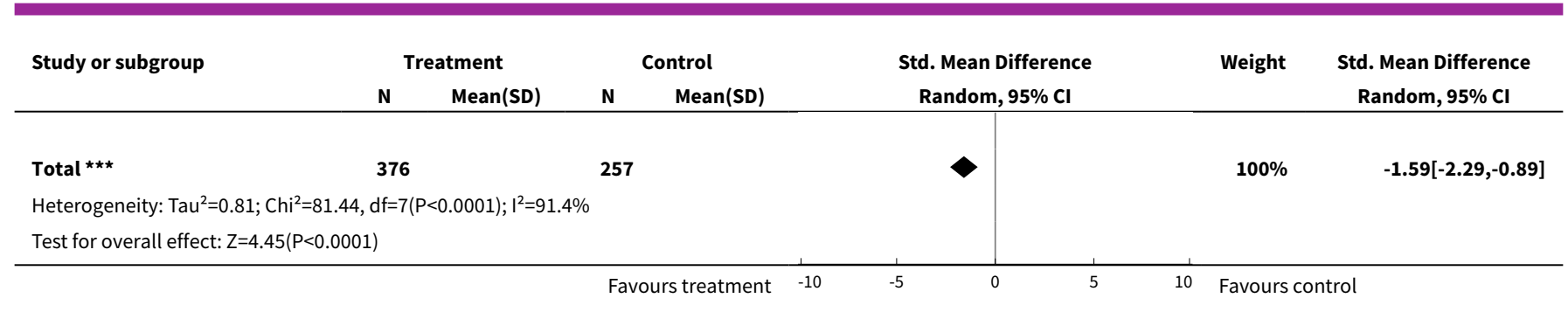

Analysis 1.5. Comparison 1 Active versus placebo, Outcome 5 Bronchial symptom.

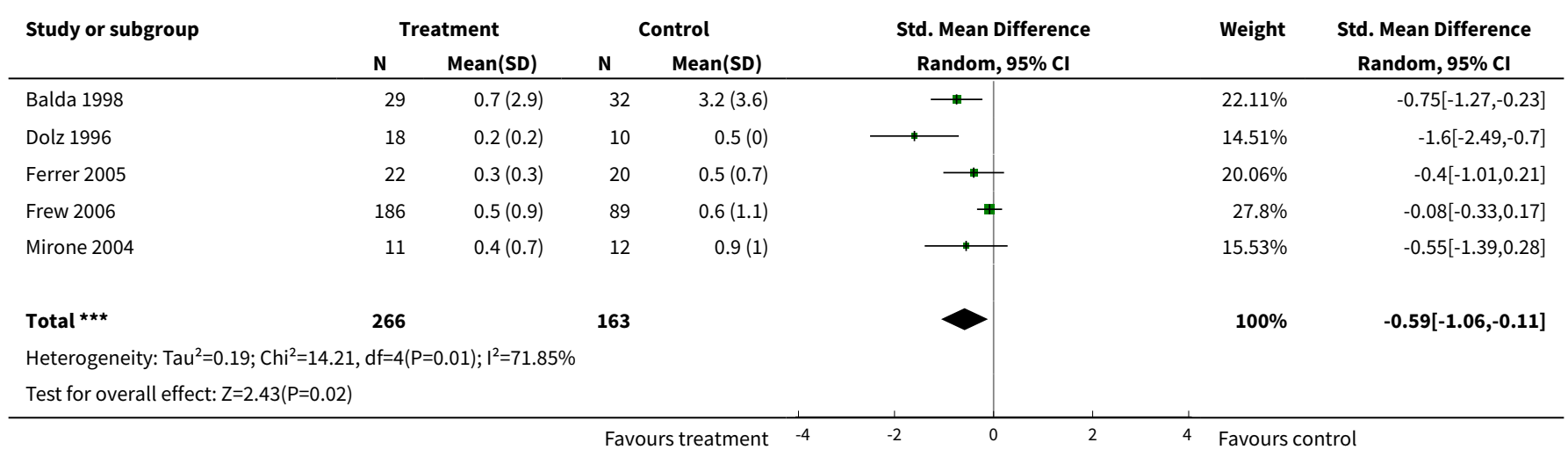

Analysis 1.6. Comparison 1 Active versus placebo, Outcome 6 Ocular symptom.

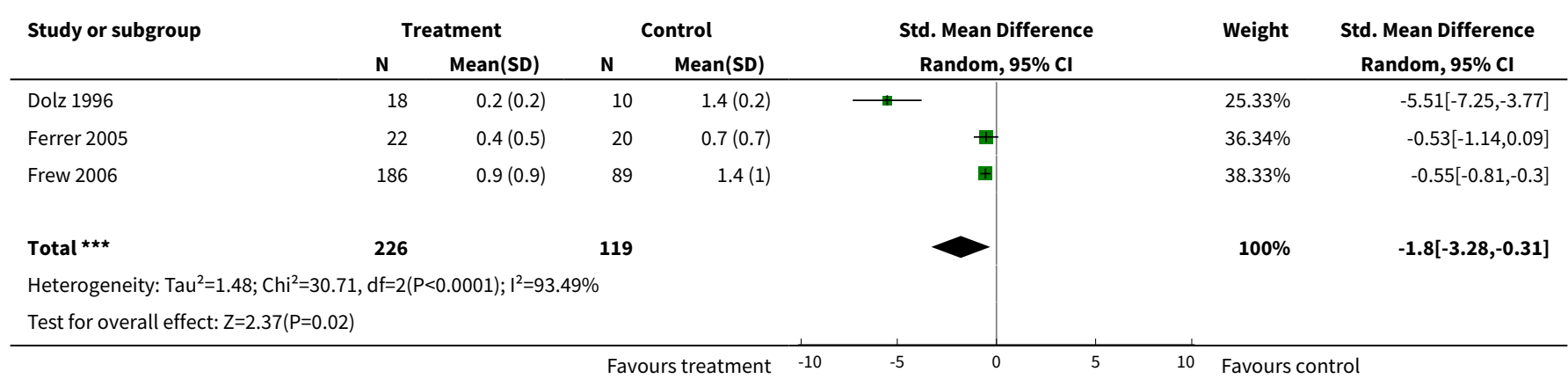

Analysis 1.7. Comparison 1 Active versus placebo, Outcome 7 IgG.

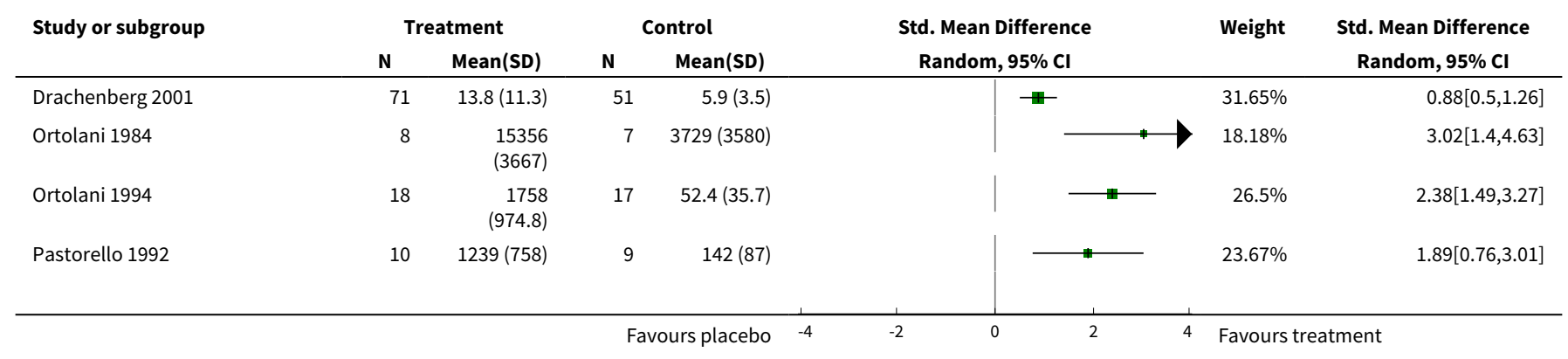




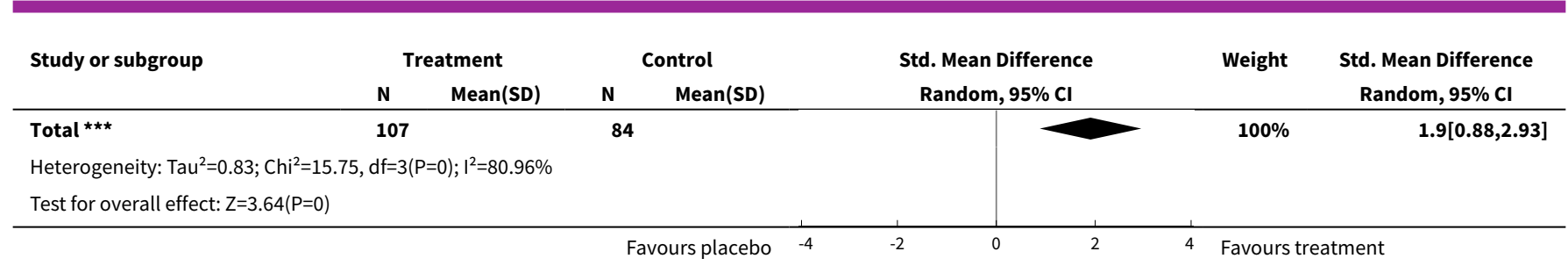

Analysis 1.8. Comparison 1 Active versus placebo, Outcome 8 IgG-4.

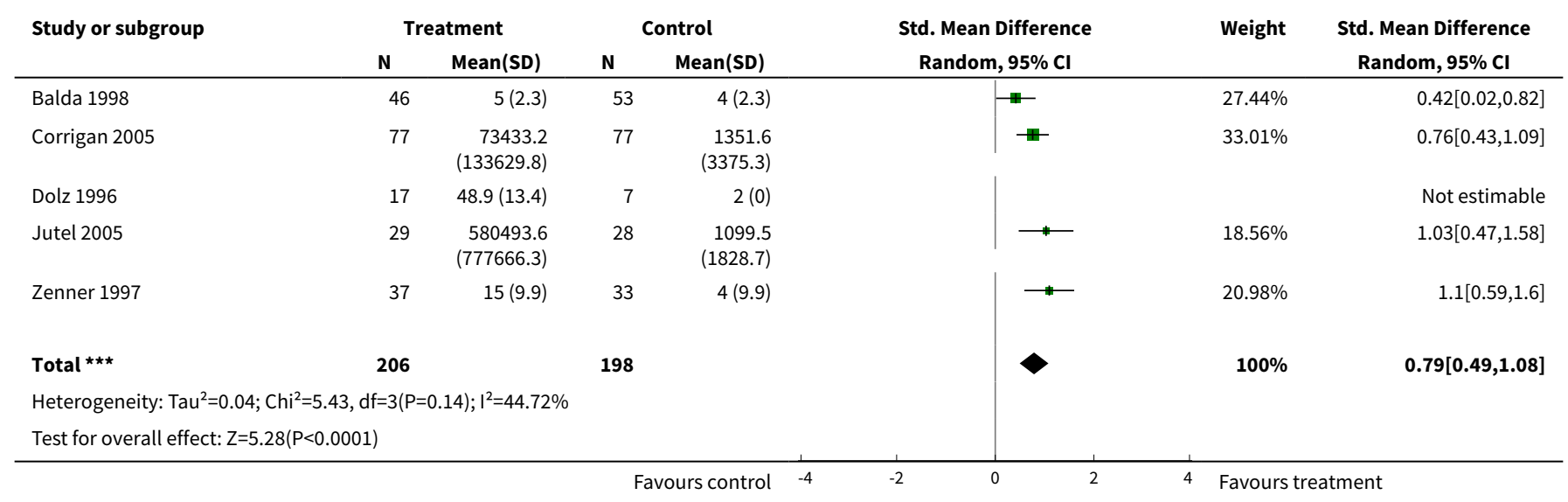

Analysis 1.9. Comparison 1 Active versus placebo, Outcome 9 Rhinoconjunctivitis Quality of Life score.

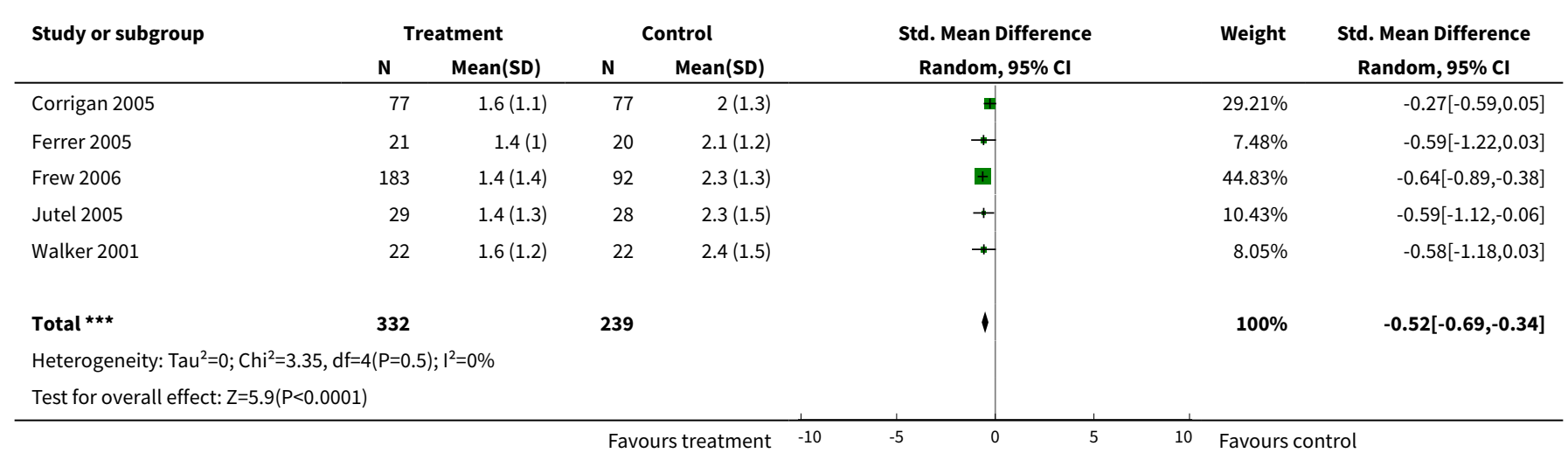

\section{ADDITIONAL TABLES}

Table 1. Symptom score results: studies not in meta-analysis

\begin{tabular}{ll}
\hline Study ID & Results \\
\hline Alvarez-Cuesta 2005 & A significant improvement in symptom scores $(P<0.0001)$ was observed in the immunotherapy \\
treated group compared with the placebo group (median (first and third quartiles) 4.00 (3.52 to \\
$4.45)$ and 5.85 (4.96 to 6.81), respectively).
\end{tabular}




\section{Table 1. Symptom score results: studies not in meta-analysis (Continued)}
Armentia-Medina 1989
Patients who received specific immunotherapy demonstrated greater clinical improvement than the control group $(P<0.001)$.

\section{Arvidsson 2002}

Median symptom scores in the specific immunotherapy and placebo groups during the first pollen season were 1.3 (range 0 to 5.2) and 2.1 (range 0.6 to 5.6), $P=0.05$. During the second pollen season the median symptom scores were 2.6 (range 0 to 6.5 ) and 4.3 (range 2.4 to 9.1), $\mathrm{P}=0.005$.

\begin{tabular}{|c|c|}
\hline Bousquet 1987b & $\begin{array}{l}\text { Symptoms recorded during the peak of the pollen season were significantly reduced }(P<0.01) \text { in } \\
\text { the specific immunotherapy group }(61 \pm 35) \text { compared to placebo group }(109 \pm 33) \text {. }\end{array}$ \\
\hline
\end{tabular}

\begin{tabular}{ll}
\hline Bousquet 1988 & Symptom scores were significantly $(\mathrm{P}<0.005)$ reduced in the group of patients treated with aller- \\
goids, the mean number of symptomatic days ranged from $12.1 \pm 11.3$ in the specific immunothera- \\
py to $25.9 \pm 3.8$ in the placebo group.
\end{tabular}

\begin{tabular}{ll}
\hline Brunet 1992a & During the ragweed pollen season, daily symptom scores were significantly lower in the specific \\
immunotherapy group than in patients receiving placebo $(4.7 \pm 0.7$ versus $7.5 \pm 1.2 ; P<0.05)$.
\end{tabular}

$\begin{array}{ll}\text { Ceuppens } 2004 & \text { We were unable to obtain complete symptom score data from the authors of this study, which is } \\ \text { available only in abstract form. }\end{array}$

Charpin $2003 \quad \begin{aligned} & \text { A non-significant improvement }(17 \%) \text { in rhinitis symptoms was found at the peak of the } 2001 \\ & \text { pollen season. However, there was a significantly greater improvement at the peak of the } 2002 \\ & \text { pollen season }(49 \%, P<0.01) \text {. }\end{aligned}$

D'Amato $1995 \quad$ Patients in the specific immunotherapy group indicated a mean decrease from 77.2 to 29.6 (62\%) after year one and from 77.2 to $24.6(68 \%)$ after year two in nasal blockage. These same patients indicated a mean improvement from 70.4 to 26.0 (63\%) after year one and from 70.4 to $27.8(61 \%)$ after year two in rhinorrhoea. They also indicate a mean decrease from 68.7 to 29.4 (57\%) after year one and from 68.7 to 25.1 (64\%) after year two in sneezing. All these improvements were significantly $(P<0.01)$ greater than those indicated by the placebo group.

\begin{tabular}{ll}
\hline Drachenberg 2002 & The active group $(n=57)$ has a significant superiority during the pollen season $(P=0.028)$ com- \\
pared to the placebo group $(n=27)$.
\end{tabular}

Grammer $1982 \quad$ Symptom score indices of the specific immunotherapy group were significantly lower than those of the placebo control group $(P=0.024)$.

$\begin{array}{ll}\text { Hauser } 1997 & \text { The clinical improvement in the active treatment group at the end of the season was greater that } \\ \text { the comparatively small placebo effect in the control group, and the difference between the groups } \\ \text { was statistically significant }(P<0.01) .\end{array}$

$\begin{array}{ll}\text { Juniper } 1985 & \text { In year one participants who received polyethylene glycol }(P E G) \text {-modified ragweed extract con- } \\ & \text { sistently recorded less severity and duration of all symptoms, although this was not significant. In } \\ & \text { year two the } P E G-\text { modified ragweed treated participants recorded significantly less overall symp- } \\ & \text { tom severity }(P=0.007) \text { and duration }(P=0.047) .\end{array}$

Leynadier 2001 The overall symptoms score (mean area under curve (AUC)) was not significantly different between the immunotherapy group and the placebo group during grass-pollen exposure (49.6 versus 56.0, respectively).

\begin{tabular}{ll}
\hline Metzger 1981 & $\begin{array}{l}\text { A mean seasonal symptom score was computed for each subject and the mean total seasonal } \\
\text { scores showed a significant difference }(P<0.02) \text { for the placebo and treated groups. }\end{array}$ \\
\hline Mirone 2004 & $\begin{array}{l}\text { A significant }(P<0.008) \text { improvement in symptom scores was observed in the immunotherapy } \\
\text { treated group compared with the placebo group (median (interquartile range) } 4.5(3.6-9.1) \text { and } 9.3 \\
(4.1-12.9), \text { respectively). }\end{array}$
\end{tabular}


Table 2. Medication score results: studies not in meta-analysis

\begin{tabular}{|c|c|}
\hline Study ID & Results \\
\hline Alvarez-Cuesta 2005 & $\begin{array}{l}\text { A significant improvement in medication scores }(P<0.0001) \text { was observed in the immunothera- } \\
\text { py treated group compared with the placebo group (median (first and third quartiles) } 1.17 \text { (1.10 to } \\
1.32 \text { ) and } 1.67 \text { ( } 1.53 \text { to } 1.88) \text {, respectively). }\end{array}$ \\
\hline Arvidsson 2002 & $\begin{array}{l}\text { The placebo group used significantly more rescue medication than the specific immunotherapy } \\
\text { group during both seasons }(P=0.004 \text { in } 1997 \text { and } P=0.004 \text { in 1998). }\end{array}$ \\
\hline Brunet 1992a & $\begin{array}{l}\text { The types and amounts of symptomatic medication taken by patients of either groups were not } \\
\text { statistically different }(0.9 \pm 0.2 \text { versus } 0.7 \pm 0.2 ; P=0.6) \text {, and most importantly, patients with lower } \\
\text { symptom scores (specific immunotherapy group) actually took less medication. }\end{array}$ \\
\hline Ceuppens 2004 & $\begin{array}{l}\text { We were unable to obtain complete medication score data from the authors of this study, which is } \\
\text { available only in abstract form. }\end{array}$ \\
\hline Charpin 2003 & $\begin{array}{l}\text { No statistical difference was observed between the two groups of patients for medication con- } \\
\text { sumption which nevertheless remained limited. }\end{array}$ \\
\hline D'Amato 1995 & $\begin{array}{l}\text { Most patients in the specific immunotherapy group were able to decrease their medication usage } \\
\text { during the course of the study. It did not appear that increasing medication use contributed to the } \\
\text { efficacy observed in the active treatment group. }\end{array}$ \\
\hline Drachenberg 2002 & $\begin{array}{l}\text { The need for symptomatic medication was significantly less with the active group than with place- } \\
\text { bo }(P=0.019) \text {, the mean scores differed about fivefold. }\end{array}$ \\
\hline Juniper 1985 & $\begin{array}{l}\text { In year one the group one subjects required less antihistamines, nasal spray and eye drops, but this } \\
\text { only reached overall significance for the eye drops }(P=0.02) \text {. In group two no difference in med- } \\
\text { ication use was observed between specific immunotherapy and placebo groups. In year two, al- } \\
\text { though the use of medications was less, it only reached significance for nose spray }(P=0.014) \text { and } \\
\text { eye drops }(P=0.025) \text { during week six of the pollen season. }\end{array}$ \\
\hline Leynadier 2001 & $\begin{array}{l}\text { The total medication score (mean AUC) was significantly lower in the immunotherapy group than } \\
\text { in the placebo group ( } 11 \text { versus } 41, P<0.01 \text { ). }\end{array}$ \\
\hline Metzger 1981 & $\begin{array}{l}\text { A statistically significant difference was found between the placebo and treated groups for daily } \\
\text { drug usage. }\end{array}$ \\
\hline Mirone 2004 & $\begin{array}{l}\text { A significant }(P<0.0008) \text { improvement in medication scores was observed in the immunotherapy } \\
\text { treated group compared with the placebo group (median (interquartile range) } 0.6 \text { ( } 0 \text { to } 2.4 \text { ) and } 2.8 \\
(0.3 \text { to } 4.4) \text {, respectively). }\end{array}$ \\
\hline Zenner 1997 & $\begin{array}{l}\text { The use of symptomatic drugs depended significantly on the severity of symptoms }(P<0.001) \text {. } \\
\text { Symptomatic drugs were used in the specific immunotherapy group for } 26.6 \% \text { of the } 70 \text { days }(10 \\
\text { weeks) with strongest symptoms during the grass pollen season and for } 33 \% \text { of the days in the } \\
\text { placebo group }(P=0.296) \text {. }\end{array}$ \\
\hline
\end{tabular}

Table 3. Symptom \& medication score results: studies not in meta-analysis

\begin{tabular}{ll}
\hline Study ID & Results \\
\hline Ariano 1999 & $\begin{array}{l}\text { The specific immunotherapy group showed a significant improvement already in year } 1 \text { of treat- } \\
\text { ment in comparison to the placebo group }(P=0.02) \text {. After switching to the active treatment the for- }\end{array}$
\end{tabular}


Table 3. Symptom \& medication score results: studies not in meta-analysis (Continued)

mer placebo group also showed a significant improvement from baseline values and their symptoms scores approximated those of the specific immunotherapy group.

Bousquet 1987 a

Arithmetic means of daily medication scores and symptom scores showed a significant reduction in symptoms and medication use in the two treated groups (mixed pollen allergoid and standardised orchard grass pollen extract $(P<0.05$ to $P<0.005)$. Patients treated with the standardised orchard grass pollen extract had lesser symptoms and lower medication scores, but the difference did not reach significance.

Bousquet 1988

There was a significant correlation $(P<0.03)$ between the number of days with symptoms and the severity of symptoms or medication scores in the specific immunotherapy group.

Bousquet 1991

Patients in both treated groups had a lower mean symptom-medication score. Only patients placed in the grass pollen treated groups had a significant clinical improvement by comparison to placebo treatment $(P<0.04)$. Some polysensitised patients placed in the specific immunotherapy group were largely improved.

Fling 1989

There were no significant differences between the symptom/medication scores of the active treatment group and the placebo-treated group. The authors stated that the pollen count during the 1987 season was quite low.

Grammer 1983 The symptom score indices of the individually polymerised grass group were significantly lower than those of the placebo control group.

Grammer 1986

IPG-treated patients had statistically lower symptom/medication scores in all weeks during the defined season $(P<0.05)$. Also, the season total and season rhinitis symptom/medication scores of IPG-treated patients for the period of evaluation were significantly lower than those of the placebo treated patients $(\mathrm{P}<0.05)$.

Grammer 1987

The scores of the PRW-treated patients were significantly lower than those of the placebo treated patients. In addition, the PRW treated patients had statistically lower rhinitis symptom/medication scores in all three weeks of the primary pollen season $(P=0.005)$ and in all five weeks of the secondary pollen season $(P=0.02)$. The $P$ values for the median weekly total symptom/medication scores are similar except for the fifth week of the secondary season, which is not significant.

Iliopoulos 1991

Patients receiving immunotherapy treatment reported significantly $(P<0.04)$ less severe symptom/medication scores than the placebo treated group during the pollen season.

Karmaker 1994

Before immunotherapy, it was observed that patients in both specific immunotherapy and placebo-treated groups had a similar mean symptom/medication score, whereas, after treatment only the specific immunotherapy treated patients had a significant clinical improvement compared to placebo treatment $(P<0.005)$. NOTE: mean values not given for inclusion in meta-analysis.

Lee 1982

Symptom and medication scores showed no statistically significant difference between the serial dilution end point titration (SDET), conventional immunotherapy and placebo groups. They all reached peak scores in early January and the scores all fell in parallel fashion thereafter. After several weeks of treatment, there was a trend in which the placebo group had the highest symptom/medication scores, the SDET had the lowest and the conventional immunotherapy group was intermediate.

Leynadier 2001

The cumulative symptom/medication score was significantly lower in the immunotherapy group than in the placebo group (64.5 versus $102.3, \mathrm{P}<0.05)$.

Litwin 1991

There was a statistically significant difference $(P=0.0001)$ between both active treatment groups' scores for total symptoms and medication compared with the placebo group. This difference was even greater when comparisons were made at the peak of the pollen season $(P<0.0001)$.

Norman 1982

The arithmetic mean score was 8.8 for the placebo and 5.1 and 5.3 for the allergoid and allergen groups, respectively. The differences between either of the two groups and the placebo group were 
Table 3. Symptom \& medication score results: studies not in meta-analysis (Continued)

significant $(\mathrm{P}<0.01)$. There was, however, no significant difference between the scores of allergen and allergoid groups.

Parker 1989

Symptom/medication scores were significantly lower in the actively treated group versus the placebo treated group ( 57.0 versus $129.9, P=0.0001$ ). There were no significant differences in symptom/medication scores for subjects with single positive skin tests versus subjects with multiple positive skin tests ( 87.5 versus $94.4, P=0.6648$ ).

Tari 1997

Comparison of the active treatment and placebo groups during the first year of the study showed significant differences between the groups in their response to natural exposure to the allergen as reflected in symptom scores and use of medication. Both the morning and evening nasal inspiratory peak flow (NIPF) rates were significantly increased in the active treatment group after 12 and 24 months. There were no significant increases in the placebo group after 12 months, but after treatment during the second year of the study, this group also recorded a significant improvement. In both groups of patients, the nasal inspiratory peak flow measurements were lower in the morning than in the evening.

\section{Table 4. Nasal symptom scores: studies not in meta-analysis}

\begin{tabular}{ll}
\hline Study ID & Results \\
\hline Bousquet 1989 & $\begin{array}{l}\text { Participants in the placebo-treated group had a significantly higher mean score for symptoms } \\
\text { and medication use than participants placed in the high-molecular-weight formalinised allergoid } \\
\text { (HMW-GOID) treatment group or standardised allergen treatment group. Patients of the unfraction- } \\
\text { ated allergoid (GOID) treatment group had a significantly greater mean number of symptomatic } \\
\text { days than patients placed in the other two treatment groups (HMW-GOID and standardised aller- } \\
\text { gen). }\end{array}$
\end{tabular}

Juniper 1985

In year one the severity and duration of nasal symptoms was significantly lower in the active treatment group in weeks three and five $(P<0.05)$ of the ragweed pollen season. In year two the PEGmodified ragweed treated subjects recorded significantly less overall nasal symptom severity $(\mathrm{P}=$ 0.03).

\begin{tabular}{ll} 
Leynadier 2001 & $\begin{array}{l}\text { Mean nasal symptoms were not significantly different between the two groups when tested as sin- } \\
\text { gle endpoints. }\end{array}$ \\
\hline Ortolani 1994 & $\begin{array}{l}\text { Actively treated patients had significantly lower nasal symptoms than placebo patients, the scores } \\
\text { were significantly lower for running nose }(P=0.0087) \text { and sneezing }(P=0.0488) \text {. Nasal blockage was } \\
\text { also less frequent in the active group than in the placebo group, but the difference did not achieve } \\
\text { statistical significance. }\end{array}$
\end{tabular}

Pastorello 1992

Actively treated patients had significantly $(P<0.01)$ lower nasal symptoms than the placebo group.

Tari 1997

Both the morning and evening nasal inspiratory peak flow (NIPF; L/min) rates were significantly increased in the active-treatment after 12 and 24 months compared with placebo group.

Varney 1991

There was a significant reduction in total nasal symptoms ( $P=0.02,49$ versus 143 (38 to 111)), blocked nose ( $P=0.03,12$ versus 44 ( 3 to 42$)$ ), runny nose $(P=0.03,11$ versus 43 ( 5 to 43$)$ ) when Alutard SQ was compared with placebo. Note: data for individual symptoms were presented as median Alutard versus median placebo ( $95 \% \mathrm{Cl}$ for difference between medians).

Walker 2001

Comparison of 1998 with 1996 showed that the symptom scores (median differences) fell by $49 \%$ in the immunotherapy group and $15 \%$ in the placebo group $(P=0.01)$. 
Table 5. Bronchial symptom scores: studies not in meta-analysis

\begin{tabular}{|c|c|}
\hline Study ID & Results \\
\hline Arvidsson 2002 & $\begin{array}{l}\text { No significant differences between the groups with respect to PEF values were found during any of } \\
\text { the pollen seasons. }\end{array}$ \\
\hline Bousquet 1989 & $\begin{array}{l}\text { Patients receiving either GOID, HMW-GOID or standardised allergen had significantly lower mean } \\
\text { symptom or medication scores than patients in the placebo treated group. There was no significant } \\
\text { difference between the three treated groups. }\end{array}$ \\
\hline Bousquet 1990 & $\begin{array}{l}\text { Asthma symptom scores (mean } \pm \text { SD) were significantly lower in the high dosage }(17.4 \pm 20.2, P> \\
0.01<0.005) \text { and low dosage }(12.8 \pm 16.8 ; P<0.001 \text { ) specific immunotherapy treated groups than in } \\
\text { the placebo group } 54.8 \pm 23.0) \text {. }\end{array}$ \\
\hline Mirone 2004 & $\begin{array}{l}\text { A significant }(P<0.0014) \text { improvement in bronchial scores was observed in the immunotherapy } \\
\text { treated group compared with the placebo group (median (interquartile range) } 0.4 \text { ( } 0 \text { to } 1.3) \text { and } 0.8 \\
\text { (0.1 to 1.9) respectively). }\end{array}$ \\
\hline Ortolani 1984 & $\begin{array}{l}\text { Mean score values for symptoms most related to lower respiratory allergy (shortness of breath, } \\
\text { wheezing and cough) were lower in the treated group than the placebo }(P<0.01) \text {. }\end{array}$ \\
\hline Ortolani 1994 & Lung symptoms were negligible in both groups and were not considered in the statistical analysis. \\
\hline Pastorello 1992 & $\begin{array}{l}\text { Actively treated patients had significantly }(\mathrm{P}<0.05) \text { lower bronchial symptoms than the placebo } \\
\text { group. }\end{array}$ \\
\hline Varney 1991 & $\begin{array}{l}\text { Chest symptoms were reduced in the active group after immunotherapy treatment when com- } \\
\text { pared with placebo groups, but these differences were of only borderline significance. }\end{array}$ \\
\hline Walker 2001 & $\begin{array}{l}\text { Comparison of } 1998 \text { with } 1996 \text { showed that chest symptom scores (median differences) were re- } \\
\text { duced by } 90 \% \text { in the immunotherapy group compared with } 11 \% \text { in the placebo group }(P<0.05) \text {. } \\
\text { After two years of treatment there was no seasonal decrease in methacholine } P C 20 \text { in the im- } \\
\text { munotherapy-treated group, compared with a reduction of almost three doubling doses ( } 32 \text { to } 4.5 \\
\mathrm{mg} / \mathrm{mL} \text { ) in the placebo group }(\mathrm{P}=0.04) \text {. }\end{array}$ \\
\hline Zenner 1997 & $\begin{array}{l}\text { Median bronchial symptoms were not significantly different if tested as single endpoints, however, } \\
\text { the largest reduction ( } 52 \%) \text { of mean symptom scores was observed for bronchial symptoms. Signif- } \\
\text { icance was obtained with simultaneous analyses of nasal and bronchial symptoms }(P=0.03) \text {. }\end{array}$ \\
\hline
\end{tabular}

Table 6. Ocular symptom scores: studies not in meta-analysis

\begin{tabular}{ll}
\hline Study ID & Results \\
\hline Bousquet 1989 & $\begin{array}{l}\text { Patients receiving either GOID, HMW-GOID or standardised allergen had a significantly lower symp- } \\
\text { tom scores than patients in the placebo treated group, but patients in the HMW-GOID group had } \\
\text { very few symptomatic days. }\end{array}$ \\
\hline
\end{tabular}

Charpin $2003 \quad$ A statistically significant improvement $(48 \% ; P<0.03)$ in conjunctivitis symptom score was found at the peak of the 2001 pollen season. This significant improvement was even greater at the peak of the 2002 pollen season $(63 \% ; \mathrm{P}<0.01)$.

Dolz 1996

The conjunctival symptoms showed a statistically significant improvement $(P<0.001)$ during the three years of the study. Active group $n=18$, mean 0.15 (SD 0.22) and placebo group $n=10$, mean 1.36 (SD 0.20).

Juniper 1985

In year one the severity and duration of eye symptoms was significantly lower in the active-treatment group in week three and five $(P<0.05)$ of the ragweed pollen season. In year two the PEG- 
Table 6. Ocular symptom scores: studies not in meta-analysis (Continued)

modified ragweed treated subjects recorded significantly less overall eye symptom severity $(\mathrm{P}=$ 0.006).

\begin{tabular}{ll}
\hline Leynadier 2001 & Mean conjunctival symptoms were not significantly different between the two groups when tested \\
as single endpoints (mean scores (AUC) given but not SD values).
\end{tabular}

Ortolani $1994 \quad$ No differences were detected for eye symptoms between active and placebo groups.
Pastorello 1992 Actively treated patients had significantly $(\mathrm{P}<0.05)$ lower conjunctival symptoms than the placebo group.

Varney 1991

There was a significant reduction in total eye symptoms $(P=0.02,37$ versus $87(10$ to 82$))$ and streaming eyes ( $P=0.02,0$ versus 5 (0 to 9)) when Alutard SQ was compared with placebo. Itching eyes were also reduced but these differences were of only borderline significance. Note: data were presented as median Alutard versus median placebo ( $95 \% \mathrm{Cl}$ for difference between medians).

Zenner 1997

Median conjunctival symptoms were not significantly different if tested as single endpoints. Significance was obtained with simultaneous analyses of nasal and conjunctival symptoms $(P=0.042)$.

Table 7. Global improvement

\begin{tabular}{ll}
\hline Study ID & Results \\
\hline Ariano 1999 & $\begin{array}{l}\text { A self-assessment of the efficacy of specific immunotherapy was performed after one year via ques- } \\
\text { tionnaire }(+31.6 \% \text { in immunotherapy group versus }-15 \% \text { in placebo, } \mathrm{P}=0.01) \text {. The actively treat- } \\
\text { ed patients reported a subjective improvement from year one and this improvement remained un- } \\
\text { changed during the whole treatment period up to four years after the discontinuation of specif- } \\
\text { ic immunotherapy. The former placebo group improved after switching to active treatment and } \\
\text { maintained this improvement up to four years after specific immunotherapy discontinuation. }\end{array}$
\end{tabular}

Balda 1998

The general analysis of all patients with an evaluable diary (intention-to-treat group) showed a significantly lower $(P=0.041)$ median maximum increase of the overall symptom score during exposure to hazel/alder pollen, with 1.5 in the specific immunotherapy treated group $(n=46)$ and 6.0 in the placebo group $(n=51)$.

Bodtger 2002

A significant improvement in patients' global improvement was reported in the specific immunotherapy group nine months after specific immunotherapy started compared with the placebo group.

D'Amato 1995

Significantly $(P<0.01)$ more patients in the specific immunotherapy group assessed their rhinitis symptoms as being better or much better (eight of nine, $89 \%$ ) compared with the placebo group ( 0 of $11,0 \%)$.

\section{Ferrer 2005}

According to clinician's (77\%) and patients' (72\%) criteria, patients who received active treatment with immunotherapy had a significant clinical improvement $(P<0.03)$ in their allergic disease.

A statistically significant difference was found between the placebo and treated groups for global evaluation.

Pastorello 1992

Data obtained directly from the authors indicated that after one year of treatment with immunotherapy 8 out of 10 patients receiving active treatment had a global improvement compared with 2 out of 9 patients receiving placebo.

Varney 1991

Post-seasonal assessments of the Alutard SQ treated groups according to the physician's and patients' assessments were measured on a scale from -3 ("a lot worse") to +3 ("a lot better"). The median values were determined and active versus placebo were compared, the $P$ value was $<0.001$ for 
Table 7. Global improvement (Continued) both the physician $(95 \% \mathrm{Cl}$ for difference in medians 2,3$)$ and patient assessment $(95 \% \mathrm{Cl}$ for difference medians 1,2) in favour of Alutard SQ.

Zenner 1997

Data obtained directly from the authors indicated that after 25 weeks treatment with immunotherapy 26 out of 41 patients receiving active treatment had a global improvement compared with 20 out of 40 patients receiving placebo.

Table 8. Specific IgG

\begin{tabular}{ll}
\hline Study & Result \\
\hline Armentia-Medina 1989 & $\begin{array}{l}\text { A significant increase }(\mathrm{P}<0.05) \text { in specific IgG levels was detected in treated patients compared to } \\
\text { controls. }\end{array}$ \\
\hline Bousquet 1987a & $\begin{array}{l}\text { Patients who received the placebo had similar mean IgG levels before and after specific im- } \\
\text { munotherapy. By contrast, patients who were treated with either six-mixed grass pollen allergoid } \\
\text { or with the standardised allergen extract had a significant increase in IgG. }\end{array}$ \\
\hline Bousquet 1987b & $\begin{array}{l}\text { Serum grass pollen IgG levels were significantly increased }(\mathrm{P}<0.01) \text { in the treated group }(233 \pm 154) \\
\text { compared to placebo group }(103 \pm 12) \text { but there was no significant correlation between their titer } \\
\text { and NPT or symptom scores. }\end{array}$ \\
\hline
\end{tabular}

Bousquet 1988 Mean serum-specific IgG titer was significantly increased $(P<0.01)$ in the allergoid treated group, whereas it remained stable in the placebo treated group.

Bousquet 1989

Patients receiving either GOID, HMW-GOID or standardised allergen had significantly increased specific IgG levels (\% binding) after specific immunotherapy $(\mathrm{P}<0.01, \mathrm{P}<0.005$ and $\mathrm{P}<0.005$ respectively). There were no mean serum changes in the placebo group.

Bousquet $1990 \quad$ Mean serum-specific IgG level did not change after specific immunotherapy in the placebo treated group, whereas it was significantly $(\mathrm{P}<0.01$ and $\mathrm{P}<0.001)$ increased in both treated groups.

Bousquet 1991

Mean serum specific IgG level did not change after specific immunotherapy in the placebo treated group, whereas it was significantly $(P<0.02$ and $P<0.04)$ increased in both active treated groups. There was no significant correlation between nasal symptom/medication scores and IgG or IgE levels.

Brewcczynski 1999 There was an increased in total IgG levels after one year specific immunotherapy treatment in the treated group compared with placebo.

\section{Brunet 1992}

IgG levels were significantly higher in the group of treated patients as compared to levels in untreated patients $(P<0.01)$.

\section{Ceuppens 2004}

Dolz 1996
Incomplete data in abstract, no reply from authors.

The determination of specific IgG detected significant differences between the active group and the placebo group $(P<0.001)$. A significant increase in specific $\lg G$ was observed in the specific immunotherapy group at the end of the study compared to the initial time of the study. No changes were observed in the placebo group.

Drachenberg 2001
Blood levels of pollen-specific IgG antibody were raised significantly $(P=0.01$ for all data points except baseline) by active treatment and another such rise was seen at the middle of the assessment period. 
Table 8. Specific IgG (Continued)

Fling 1989

A significant difference was noted before the season and intraseasonally, with the specific immunotherapy group having greater amounts of specific IgG compared to the placebo group, $\mathrm{P}=$ 0.018 and 0.028 , respectively.

Grammer 1982

Total serum antibody against AgE was measured. In the specific immunotherapy group there was a greater than 40 -fold increase in blocking antibody, while there was no change in placebo treated patients.

Grammer 1983

A modest rise in IgE directed against rye grass group 1 (RGG1). However, after 48,000 PNU of individually polymerised grass, blocking antibody against RGG1 rose nine-fold, averaging $591 \mathrm{ng}$ RGG1 bound/ml.

Grammer 1986

In the IPG-treated patients, there was a statistically significant eleven-fold increase in IgG to grass pollen $(P<0.0007)$ whereas there was no change in placebo treated patients.

Grammer 1987

The change in IgE against AgE in placebo and PRW treated patients showed a statistically significant 1.3-fold rise in PRW treated patients $(P=0.0024)$ but no change in placebo treated patients.

Hauser 1997

Increases in the grass-specific IgG were only detectable in the active treatment group. The median value immediately after therapy was $158 \%$ greater that the initial value, and at this point and the three time points during the pollen season, the allergen specific IgG level was significantly higher in the treatment group as compared with the placebo group $(P=0.0007, P=0.0043, P=0.0005, P=$ 0.0014 , respectively). There were no significant changes in the placebo group.

Iliopoulos 1991

After the ragweed season, the difference between immunotherapy treated and placebo treated groups was statistically significant ( 2445 versus $500 \mathrm{ng} / \mathrm{ml}$; $<0.001$ ) for specific IgG levels.

Juniper 1985

Injections of PEG-modified ragweed also stimulated increases in IgG; when the increases were compared with placebo treated group levels, the increase reached significance both in year 1 (both groups $P=0.032)$ and also in year $2(P=0.008)$. Both years the increases in IgG were linearly related to the total dose of PEG-modified ragweed injected $(P<0.0001)$.

Karmakar 1994

After immunotherapy specific IgG levels were statistically significant higher $(P<0.025)$ in the specific immunotherapy treated group (mean SD; 582 26) compared to placebo group (mean SD; 469 37).

Litwin 1991

After immunotherapy treatment, the mean increase of specific IgG was $106.4 \%$ in Pool 2-treated patients and $59.1 \%$ in fSRW-treated patients $(P<0.05)$. The difference between the two groups was not statistically significant. Specific IgG increased $1 \%$ in placebo treated patients. However, there was a fall in specific IgG levels during seasonal exposure for both active treated groups, $-10.1 \%$ in the fSRW-group and $-3.2 \%$ in the Pool 2-treated patients. The decreased seasonal specific IgG found in each of these two groups was statistically significant when compared with the placebo treated patients $(P<0.05)$ but not when compared with each other.

Meriney 1986

In the treatment group, post-treatment blocking antibodies levels showed a consistent and significant rise compared with pre-treatment levels $(P=0.001)$. No significant rise in blocking antibody levels after therapy was observed in the control group. Absolute levels of post-treatment blocking antibody were significantly higher in the treatment group when compared to the control group $(\mathrm{P}=$ 0.01 ), although there was no such difference prior to therapy. Post-season blocking antibody levels remained significantly elevated in the treatment group compared with the control group $(P=0.02)$.

Metzger 1981

The mean rise of antigen specific IgG was about six-fold, from $232 \mathrm{EU}$ to $1276 \mathrm{EU}$ of antibody activity $(\mathrm{P}<0.001)$.

Norman 1982

The allergoid regimen produced a more rapid serum IgG antibody response, with significantly higher post-treatment levels than those in the allergen regimen. 
Table 8. Specific IgG (Continued)

Ortolani 1984

Ortolani 1994

Pastorello 1992
Specific IgG antibody showed significant increases in treated subjects on comparison with controls after 4 months of immunotherapy $(P<0.005)$ that started from very low levels before institution of immunotherapy.

There was an increase in specific IgG associated with active treatment. The levels peaked at the third assessment (after 5 months of immunotherapy) and then stayed fairly level. No changes were observed in the placebo group.

The actively treated group showed a statistically significant increase $(P<0.0005)$ in mean IgG level after 2 months of immunotherapy (855 PNU). The maximum mean level was reached after 4 months (46,050 PNU). At subsequent determinations, after 9 and 12 months of immunotherapy, the level was somewhat below the maximum but the increase was still significant $(P<0.001)$ after 9 months and after 12 months $(P<0.02)$. No changes were observed in the placebo group.

Tari 1997

After 6 months treatment, the IgG antibody levels were significantly increased $(P<0.01)$ in the active group, and levels remained significantly greater than the baseline values at later time points in the study. No changes were detected in the placebo group.

Table 9. Specific IgG4

\begin{tabular}{ll}
\hline Study & Result \\
\hline Ariano 1999 & $\begin{array}{l}\text { A significant increase was observed in the active group (but not in the placebo one) after } 1 \text { year of } \\
\text { treatment, and this effect remained unchanged at years } 2 \text { and } 3(P<0.01) . \text { After switching to active } \\
\text { treatment, the previously placebo group also shown an increased in serum IgG4. }\end{array}$
\end{tabular}

Balda 1998

Specific IgG4 significantly increased $(P<0.001)$ in SIT group but remained unchanged in the placebo group at T1 (after therapy). IgG4 continued to increase slightly in the SIT group at T2 (in season) and decreased at T3 (after season). IgG4 only slightly increased at T2 and T3 in the placebo group.

Brewcczynski 1999

There was an increase in specific IgG4 levels after one year specific immunotherapy treatment in the treated group compared with placebo.

Dolz 1996

For specific IgG4, an important increase was seen in the active group in comparison with the control group, in which there was no change $(P<0.001)$. The increase of IgG4 was later than that of specific IgG, although it reached high and progressive values.

Fling 1989

No significant differences for specific IgG4 levels were present between the treated patients and those receiving placebo before specific immunotherapy, but levels were significantly higher in the specific immunotherapy treated group before the season and intraseasonally.

Jutel 2005

IgG4 concentrations showed a continuing upward trend, achieving an approximately 4000 -fold increase by the end of treatment. Comparisons between the groups showed statistically significant differences at all time points after the commencement of immunotherapy $(P<0.001)$.

Leynadier 2001

Mean serum specific lgG4 levels in the immunotherapy group increased more than fivefold (from $3.2 \%$ to $17 \%, \mathrm{P}<0.001$ ) during the pollen season, then decreased slightly after the season (from $17 \%$ to $10.7 \%)$. In the placebo group, specific IgG4 levels remained unchanged during and after the pollen season.

Ortolani 1984

Significant increases were observed in each of the four IgG subclasses with a statistically greater increase of IgG4 $(P<0.05)$ relative to baseline when compared with IgG antibodies 1 to 3 . After achieving maintenance dose around the fifth month of therapy, a decrease in IgG antibodies of all subclasses was observed. This decrease was significant for total IgG class antibodies in October 
Table 9. Specific IgG4

(Continued)

as compared to April $1981(P<0.05)$. Nevertheless, differences in IgG and IgG antibodies 1 to 4 between treated subjects and controls remained highly significant at the end of the trial.

Ortolani 1994

In the active group, P.j.-specific IgG1 peaked after 5 months of immunotherapy and then declined; P.j.-specific IgG4 antibodies reached their peak levels at the same assessment, but remained high. No changes in specific IgG1 and IgG4 levels were detected in the placebo group.

Parker 1989

Both MC slgG1 and MC slgG4 levels were significantly higher in actively treated subjects than in control subjects, $P<0.001$. Both MC slgG1 and MC slgG4 levels rose in the placebo treated subjects, presumably because of natural exposure to $M C$ pollen, $P=0.0479$ and $P=0.0024$, respectively.

Pastorello 1992

Specific Ig4 showed a significant increase $(P<0.05)$ after 2 months of immunotherapy, followed by a constant increase, reaching the maximum mean level after 4 months. This level remained constant until after 12 months. No changes were observed in the placebo group.

Tari 1997

Specific IgG1 levels were significantly increased after 6 months of active treatment $(P<0.01)$, but decline thereafter as the treatment continued. Increases in specific IgG4 were not seen until 12 months after commencement of therapy, and levels remained significantly raised during the second year of treatment. There were no significant changes in IgG1 and IgG4 in the placebo group.

Zenner 1997

Specific IgG4 levels with specific immunotherapy were increased at T1 by more than $400 \%(\mathrm{P}<$ 0.001 ) and continued at this level up to T3. Patients treated with the maximum dose of $1000 \mathrm{SE}$ had higher levels of IgG4 at T1, T2 and T3 compared to patients who received lower doses.

Table 10. Specific IgE

\begin{tabular}{ll} 
Study & Result \\
\hline Ariano 1999 & After 1 year of immunotherapy, a significant increase in specific IgE was observed only in the ac- \\
& tively treated group $(\mathrm{P}=0.004)$. Subsequently, the IgE concentration constantly and significantly \\
& decreased (baseline versus year $2: \mathrm{P}=0.04 ;$ baseline versus year $3: \mathrm{P}=0.003)$. No change was de- \\
& tectable in the placebo group after year 1 . After year 2 of immunotherapy there was a significant \\
& fall in IgE levels (baseline versus year 2: $\mathrm{P}=0.01$; baseline versus year $3: \mathrm{P}=0.006)$, this was also ob- \\
& served in the placebo group.
\end{tabular}

$\begin{array}{ll}\text { Armentia-Medina } 1989 & \begin{array}{l}\text { A significant increased }(\mathrm{P}<0.001) \text { in specific IgE in the treated patients compared to the control } \\ \text { group. }\end{array}\end{array}$

Balda 1998 The course of specific IgE in the specific immunotherapy and placebo groups showed only slight, insignificant differences from higher mean values after placebo. The adjusted mean curves were (T0-T1-T2-T3) 61,56-67.36-1.74-68.85 SU/ml in the specific immunotherapy group and 61.56-69.41-72.02-75.11 SU/ml in the placebo group.

\begin{tabular}{ll}
\hline Bodtger 2002 & $\begin{array}{l}\text { Neither the birch pollen specific IgE nor the total IgE differed significantly between the groups at } \\
\text { any measurement. Both parameters increased in both groups but only the increase in total IgE lev- } \\
\text { els in the placebo group reached significance. }\end{array}$ \\
\hline Bousquet 1987a & $\begin{array}{l}\text { Grass pollen IgE was very similar before and after specific immunotherapy in the placebo treated } \\
\text { group and was non-significantly increased in the other two treated groups. }\end{array}$ \\
\hline Bousquet 1988 & $\begin{array}{l}\text { Mean serum IgE was significantly }(\mathrm{P}<0.04) \text { increased in the allergoid treated patients }(23.7 \pm 11.6 \% \\
\text { before treatment to } 31.4 \pm 13.5 \% \text { after treatment) and remained stable in the placebo treated } \\
\text { group. }\end{array}$ \\
\hline
\end{tabular}


Table 10. Specific IgE (Continued)

Bousquet 1989
There was an increase in mean levels of specific $\lg E$ (\% binding) in patients receiving either GOID, HMW-GOID or standardised allergen, but this was only significant in the HMW-GOID treated group $(P<0.01)$. There were no mean serum changes in the placebo group.
Bousquet $1990 \quad \begin{aligned} & \text { After specific immunotherapy, mean serum-specific IgE levels increased non-significantly in the } \\ & \text { two allergoid treated groups, and there was no change in the placebo treated group. }\end{aligned}$

Brewcczynski 1999

No changes were observed in specific IgE levels after one year specific immunotherapy treatment in the treated group and the placebo group.

Brunet 1992

The significant raise of IgE in the placebo treated group observed during the ragweed pollen season, as compared to preseasonal level $22551 \pm 3779$ versus $26159 \pm 4222$ counts per minute; $\mathrm{P}<$ 0.02 ) was prevented by specific immunotherapy ( $23196 \pm 3985$ versus $24938 \pm 3952$ counts per minute; $\mathrm{P}=\mathrm{NS}$.

\begin{tabular}{ll}
\hline Ceuppens 2004 & Incomplete abstract, no reply from authors. \\
\hline Corrigan 2005 & $\begin{array}{l}\text { The median serum concentration of allergen specific IgE declined during the two treatment peri- } \\
\text { ods in both groups and over the study as a whole. Mean values (SD) were 2.32 (2.96) for the active } \\
\text { group compared with } 3.44(6.09) \text { in the placebo group. }\end{array}$
\end{tabular}

Dolz 1996

No significant changes were observed between the beginning and the end of the study for total IgE and specific IgE levels for both, the active and the placebo groups.

Drachenberg 2001

The active treatment group did not increase levels of grass pollen specific IgE antibody. In the placebo group, at the middle of the assessment period, a rise was found which was not seen in the active group $(P=0.002)$. Slight falls were observed in both groups after the end of the pollen season.

Fling $1989 \begin{aligned} & \text { There was a non-significant reduction of specific lgE levels measured during the pollen season in } \\ & \text { the specific immunotherapy compared to placebo. }\end{aligned}$

\section{Grammer 1986}

There was no statistically significant rise in IgE against grass pollen in IPG- or placebo-treated patients. Statistical analyses were performed with log transformations of the data.

In the PRW-treated patients, there was a statistically significant nine-fold rise in total antibody
binding of $\mathrm{AgE}(\mathrm{P}<0.00001)$, whereas there was no change in patients treated with placebo.

Iliopoulos $1991 \quad$ The placebo treated group had a significant increase in IgE antibodies, 1.2 versus 1.73 median log, $\mathrm{ng} / \mathrm{ml}$, related to the season $(\mathrm{P}<0.001)$. No increase occurred in the immunotherapy treated group (1.82 versus 1.71 median log, $\mathrm{ng} / \mathrm{ml}$, before and after season, respectively).

Juniper 1985

Both years injections of PEG-modified ragweed stimulated an increase in IgE, but when the changes were compared with the changes in the placebo-treated group, this only reached significance in group 1 the first year $(P=0.014)$.

Jutel 2005

Specific IgE levels were not significantly different between groups at the beginning of the study, but thereafter, those of the active treatment group were significantly less than placebo. Concentrations showed a downward trend, with values significantly less than baseline.

Karmakar 1994 After immunotherapy specific IgE levels were statistically significant higher $(P<0.001)$ in the placebo treated group (mean, SD; 783, 51) compared to specific immunotherapy group (mean, SD; 291, 32).

Lee 1982 
Table 10. Specific IgE (Continued)

Leynadier 2001

Before treatment, mean serum specific IgE levels were higher in the immunotherapy group than in the placebo group, but this difference was not statistically significant. During and after the pollen season, mean serum specific IgE levels remained unchanged in both the immunotherapy group and the placebo group.

Litwin 1991

A small increase in specific IgE occurred in both treatment groups prior to the ragweed season $(+14.2 \%$ in the Pool 2 group and $+3.9 \%$ in the fSRW group). A small decline in specific IgE (-9\%) occurred among the placebo group. Comparison between groups was not significant. However, during seasonal exposure to ragweed, the placebo treated patients showed a mean rise in specific IgE of $+89 \%$ and both allergen treatment groups abolished this expected increase. fSRW-treated patients showed the most profound effect with a mean increase in specific IgE of only $+9.9 \%$, this difference was significant $(P<0.01)$ when compared to placebo. Pool 2 treated patients also experienced a diminished anamnestic response of specific IgE as compared with placebo treated subjects with a mean increase of $+14.7 \%$, this was difference significant compared with controls $(P<$ 0.01). Although fSRW treatment seemed to produce more suppressive effect than Pool 2 treatment, the difference between the two groups was not significant.

Meriney 1986

Specific IgE levels to ragweed was measured just after completion of immunotherapy (mid-August) and again after the ragweed season. Considerable variability was found in specific IgE levels but no significant differences between groups were observed.

\begin{tabular}{ll}
\hline Metzger 1981 & $\begin{array}{l}\text { There was an increase in the mean post-treatment antigen-specific IgE antibody activity from } 17 \text { to } \\
27 \mathrm{EU}(\mathrm{P}<0.001) .\end{array}$ \\
\hline Norman 1982 & $\begin{array}{l}\text { The allergoid regimen produced a more rapid serum IgE antibody response, with significantly high- } \\
\text { er post-treatment levels than those in the allergen regimen. }\end{array}$
\end{tabular}

Ortolani 1984

IgE antibody to timothy did not show significant variations either in the serum or in the secretions of treated subjects with respect to controls. No important seasonal variations were noted.

Ortolani $1994 \quad$ No significant changes in IgE antibody level specific to P.j. pollen in undiluted and 1:5 diluted sera were detected in either actively or placebo treated patients during the entire trial.

Parker 1989

Post-seasonal levels of MC slgE were significantly lower in actively treated subjects than in control subjects, $\mathrm{P}=0.0001$.

Pastorello 1992

As compared with baseline, the actively treated group presented a significant increase in specific IgE mean level after $3(P<0.01)$ and $4(P<0.01)$ months of immunotherapy. After 9 and 12 months of immunotherapy this group showed a decrease in specific IgE mean levels, reaching a value not different from baseline. The placebo group showed no noteworthy changes in specific IgE mean levels throughout the year.

Tari 1997

Specific IgE levels in the active treatment group did not change significantly during the course of the study, although there was a progressive trend to a lower concentration. There was an increase in the placebo group, but this was not statistically significant.

Zenner 1997

Levels of specific IgE adjusted to T0 significantly increased at T1 $(P=0.006)$ for specific immunotherapy treated patients but remained unchanged for placebo. Specific IgE levels showed a parallel increase for both groups at T2. Levels continued to increase in the placebo group, but decreased slightly in the specific immunotherapy group at T3.

Table 11. Nasal Challenge

Study Result


Table 11. Nasal Challenge (Continued)

Bodtger 2002

No significant changes were observed after one year follow up (year 2000) in NPT (SQ-U) in the immunotherapy group versus placebo $(P>0.7)$.

Bousquet 1987b

Nasal challenges performed before the pollen season showed that the mean provocative dose is significantly increased $(P<0.01)$ in the treated group $(28,036 \pm 57,435)$ compared to placebo group $(860 \pm 1394)$.

Bousquet 1988

After specific immunotherapy with allergoids, the mean number of grains eliciting nasal symptoms ranged from $217 \pm 150$ grains to $14,723 \pm$ grains $(P<0.005)$. In contrast, patients who received placebo only had a slight and non-significant improvement in the provocative dose ( $430 \pm 505$ grains to $1360 \pm 3793$ grains).

Bousquet 1990

After specific immunotherapy the mean number of grains eliciting nasal symptoms ranged from $21,932 \pm 51,104$ grains $(P<0.04)$ in the low dose group or from $33,530 \pm 63,003$ grains $(P<0.01)$ in the high dose group. There were no significant differences between the two groups. The correlation between the threshold dose inducing nasal challenge and the observed symptoms of the patients during the season was highly significant $(P<0.001)$. Most patients with a positive NPT for a low number of pollen grains (50 to 250 grains) suffered from severe symptoms during the pollen season. In contrast, most patients who reacted during the NPT for a high number of pollen grains (>6250 grains) had fewer symptoms during the pollen season.

Bousquet 1991

Patients in the grass pollen treated group reacted for a significantly $(P<0.01)$ greater mean number of grains ( $m \pm S D ; 69,175 \pm 70,655$ grains) than patients in the corresponding placebo treated group (44-fold increment). In contrast, patients in the multiple pollen treated group reacted for a non-significantly greater mean number of grains ( $\mathrm{m} \pm \mathrm{SD} ; 28,687 \pm 51,437$ grains) by comparison to the corresponding placebo treatment (9.3-fold increment). There was no significant difference between active treated groups.

Brunet 1992

The ragweed specific nasal reactivity measured during the pollen season was significantly higher in the placebo treated group than in the actively treated group. More ragweed extracts were needed to induce a drop of NAR in ragweed treated patients than in placebo treated subjects, especially at PD50 ( $614 \pm 114$ versus $118 \pm 98$ PNU; $P<0.002)$ and PD75 (901 \pm 113 versus $163 \pm 114$ PNU; $P<$ $0.0001)$. Furthermore, natural exposure to pollen did not significantly affect the nasal reactivity to ragweed in ragweed treated patients $(P=0.44)$.

D'Amato 1995

After 2 years of treatment significantly more $(P<0.01)$ specific immunotherapy patients (seven of nine, $78 \%$ ) indicated improvement, relative to baseline, than did placebo patients (one of eleven, $9 \%)$.

Iliopoulos 1991

Immunotherapy significantly decreased the early reaction to nasal challenge with antigen. The levels of histamine, TAME-esterase activity and kinins, as well as the symptoms generated during the early reaction of the immunotherapy treated group, were significantly lower than the corresponding levels of the placebo treated group $(\mathrm{P}<0.02$ for all). Four to 10 hours after ER, the levels of TAME-esterase activity, kinins and symptoms generated in the entire immunotherapy-treated group were lower than the corresponding levels of the entire placebo treated group, but these difference did not reach statistical significance. Levels of histamine in the late phase reaction were the same in both groups. The levels of histamine, TAME-esterase activity, kinins and symptoms generated during the rechallenge reaction of the immunotherapy treated group were lower than the corresponding levels of the placebo treated group, but only the differences in symptoms reached statistical significance $(P<0.02)$.

Leynadier 2001

A threefold higher concentration of allergen extract (63.4 IR) was necessary in the immunotherapy group to elicit a positive response on NPT after immunotherapy $(P<0.05)$, but no such change was observed in the placebo group ( $31 \mathrm{IR}$ before immunotherapy versus 37.7 after immunotherapy, $P$ $>0.05)$. After immunotherapy, the threshold dose in the immunotherapy group was higher than in the placebo group (63.4 IR versus 37.7 IT, respectively), but these differences were not statistically significant. 
Table 11. Nasal Challenge (Continued)

Ortolani 1994

The responses to NPT in the two groups showed that only the active group presented a significant increase in the nasal threshold dose of P.J. extract after 4 and 10 months of immunotherapy $(P<$ 0.01). No correlations were found between symptom/medication scores and NPT.

Pastorello 1992

A significant decrease $(P<0.05)$ in specific nasal reactivity was detected in actively treated patients after 12 months of immunotherapy. No differences were found between the two groups after 4 months of immunotherapy. After 12 months of immunotherapy three patients no longer react to the top concentration $(10,000 \mathrm{BU} / \mathrm{ml})$. No differences were observed in the placebo group.

Tari 1997

Nasal provocation showed that there was no difference in sensitivity between the two patient groups at the beginning of the trial. After 12 months, there was a significant increase in the allergen provocation dose for the active treatment group from a median value of $600-2000 \mathrm{BU}(\mathrm{P}<0.01)$, while there was a substantially smaller yet significant difference for the placebo group $(P<0.01)$. The difference between the groups was also significant $(P<0.01)$. After the second year of treatment, the provocation dose was increased still further to $5000 \mathrm{BU}$ in the active-treatment group ( $P$ $<0.01)$.

Table 12. Conjunctival Challenge

\begin{tabular}{ll}
\hline Study & Result \\
\hline Arvidsson 2002 & $\begin{array}{l}\text { No statistically significant differences between the active and placebo groups were seen in the con } \\
\text { junctival provocation test results. }\end{array}$ \\
\hline Bodtger 2002 & $\begin{array}{l}\text { Conjunctival provocation test }(S Q-U) \text { in the specific immunotherapy groups was only significant } \\
\text { as a paired analysis }(P<0.05) \text { and not between the treatment groups, the median value did not } \\
\text { change whereas the range did. }\end{array}$
\end{tabular}

Corrigan 2005

A comparison of the two treatment groups at the end of the grass pollen season in 2003 showed a significant difference $(P<0.0001)$ in the concentration of allergen tolerated. $72 \%$ of patients in the active group improved their allergen tolerance.

Dolz 1996

The concentration of antigen necessary to make the conjunctival provocation test positive increased by $250 \mathrm{BU} / \mathrm{ml}$ in the active group $(\mathrm{P}<0.001)$ between $\mathrm{T} 0$ and T4. No changes were seen in the placebo group.

Jutel 2005

All subjects fulfilled the inclusion criterion of a positive conjunctival provocation test. At the end of the study, there was a clear trend to a higher threshold allergen dose, although this was not statistically significant $(P=0.081)$.

Ortolani 1994

A significant increase of the conjunctival threshold dose of P.j extracts (alpha fractions) was found in conjunctival provocation tests after 4 months of immunotherapy $(P<0.05)$, whereas in the placebo group no changes were found. No correlations were found between symptom/medication scores and conjunctival provocation tests.

Varney 1991

Provocation tests showed a greater than 10 -fold reduction for the active group in immediate conjunctival allergen sensitivity $(P=0.001)$ after immunotherapy treatment.

Table 13. Skin Challenge

Study Result


Table 13. Skin Challenge (Continued)
Ariano 1999
A decrease in skin reactivity was observed in both groups at year 3 of treatment from baseline for the three allergen concentrations used $(3 \mathrm{kAU} / \mathrm{ml}: 17.1$ versus $14.2 \mathrm{~mm}, \mathrm{P}=0.02 ; 10 \mathrm{kAU} / \mathrm{ml}: 22.8$ versus $19.2 \mathrm{~mm}, \mathrm{P}=0.01 ; 30 \mathrm{kAu} / \mathrm{ml} 27.2$ versus $22.6 \mathrm{~mm}, \mathrm{P}=0.002$ ).
Armentia-Medina 1989
A significant decrease $(P<0.001)$ in skin sensitivity to grass pollen was found in treated patients compared to controls.

\begin{tabular}{ll}
\hline Bodtger 2002 & Specific immunotherapy reduced cutaneous late-phase response diameters $(P<0.00001)$. \\
\hline Bousquet 1987a & $\begin{array}{l}\text { The evolution of skin tests after specific immunotherapy demonstrated that patients treated with } \\
\text { placebo did not present any significant change in their end point titer, whereas patients treated ei- } \\
\text { ther with allergoid or the standardised orchard grass pollen extract had a significant }(P<0.01 \text { and } P \\
<0.02) \text { decreased in their skin test end point. }\end{array}$
\end{tabular}

Bousquet 1988 the allergoid treated group, there was a significant $(\mathrm{P}<0.001)$ decrease in skin test end point,
whereas there was no major difference in the placebo-treated patients.

Bousquet 1989

Patients receiving either GOID, HMW-GOID or standardised allergen had a significant reduction in the mean end point titer for skin test reactivity to allergen $(P<0.04, P<0.005$ and $P<0.01$ respectively) after specific immunotherapy. There were no mean changes in the placebo group.
Bousquet 1990
After specific immunotherapy, the mean end point titer of patients treated with placebo did not change by comparison to pretreatment and was significantly greater than end point of both treat- ed groups $(\mathrm{P}<0.05$ and $\mathrm{P}<0.02)$.

There was only a significant $(\mathrm{P}<0.01)$ difference between skin tests performed before and after
specific immunotherapy in patients treated by grass pollen.

D'Amato 1995

The mean size of skin test reactions after 2 years of treatment was statistically significant $(P<0.01)$. The mean reaction had decreased 7.2, 18.4, 20.1 and $28.8 \mathrm{~mm}$, relative to baseline, at the $8,40,200$ and $1000 \mathrm{AUR} / \mathrm{ml}$ concentrations, respectively. Each of these decreases was significantly $(P<0.01)$ greater than those observed at the same concentrations in the placebo group.

Dolz 1996

The quantitative evaluation of the SPT from the onset to the end of the study showed a statistically significant decrease $(P<0.01)$ for the active group in comparison to the placebo group, which showed no significant variation. The concentration of antigen necessary to make the SPT positive increased in the active group $(\mathrm{P}<0.001)$ between T0 and T4. No changes in the placebo group.

Drachenberg 2001

There were changes in skin test activity recorded before and after therapy. Activity was significantly reduced in the active group compared with placebo group for both the threshold values $(P=0.03)$ and the total wheal areas $(P=0.04)$.

\section{Fling 1989}

The 14 paired patients were matched according to the size of the late cutaneous reaction (LCR) to an intradermal injection of $0.02 \mathrm{ml}$ of 1:1000 dilution of pollen extract. There was no significant difference in the size of the LCR before treatment in the two groups. However, there was a significant difference in the size of the LCR between the active therapy group and the group receiving placebo injection, $P<0.025$. When the percent change in the LCR from baseline to intraseason was compared, the difference became more apparent with a $\mathrm{P}<0.0005$. Interestingly, there was a significant decrease not only in the specific immunotherapy group $(P=0.018)$ but also in the placebo group $(P=0.043)$. There was a significant difference in the size of the immediate cutaneous reaction (ICR) between the 7 matched patient pairs before specific immunotherapy with larger ICR in the placebo treated group $(P<0.005)$. However, there was no significant difference in the size of the ICR between both groups at the end of the study. Also, the percent change in the ICR from baseline was similar for both groups.

Iliopoulos 1991

The 15-minute wheal generated in the immunotherapy treated group was significantly smaller than the corresponding wheal in the placebo treated group (11.25 versus 14.25 , median diameter in $\mathrm{mm} ; \mathrm{P}<0.002$ ). There was no significant difference in the 15 -minute erythema formation (45.5 versus 52.25 , median diameter in $\mathrm{mm}$ ) during the early reaction. The effect of immunotherapy on 
Table 13. Skin Challenge (Continued)

the cutaneous late phase reaction (LPR) was more pronounced. Not only was the overall cutaneous LPR of the immunotherapy treated group smaller than the cutaneous LPR of the placebo treated group (43.5 versus 303.75 , median diameter in $\mathrm{mm}$; $\mathrm{P}<0.002$ ), but the immunotherapy-treated group also developed an erythematous induration (flare) that was significantly $(P<0.002)$ smaller than the corresponding induration of the placebo treated group for every hourly measurement.

Leynadier 2001

A significant difference $(P<0.001)$ was observed for each allergen concentration tested between the skin tests performed before and after immunotherapy in patients treated by grass pollens. In contrast, no significant change in skin test responses was observed in the placebo group. For the $100 \mathrm{IR} / \mathrm{ml}$ concentration, the mean wheal diameter decreased from $9.6 \mathrm{~mm}$ before immunotherapy to $6.7 \mathrm{~mm}$ after immunotherapy in the immunotherapy group versus slight increase from $9 \mathrm{~mm}$ to $9.3 \mathrm{~mm}$ in the placebo group. Comparison of the two groups showed a highly significant increase in allergic skin threshold for the immunotherapy group $(P=0.001)$.

Mirone 2004

The active group showed a significant decrease in the skin reactivity after treatment (13.44-fold in reference to baseline, $P<0.0001)$. In contrast, a slight increase by 1.07 -fold $(P=0.87)$ was observed in the placebo group.

Ortolani 1994

There was a significant increase in the cutaneous threshold dose in the active group after $4(\mathrm{P}<$ $0.05)$ and 10 months $(P<0.01)$ of immunotherapy. No changes were observed in the placebo group. No correlations were found between symptom/medication scores and SPT.

Paraskevopoulos 2005

At the end of the up-dosing phase (approximately 8 weeks) there was a significant reduction in the size of the late phase response which was evident with all three intradermal doses $(P=0.02$ for 0.1 and $1 \mathrm{BU}$, and $\mathrm{P}=0.04$ for $10 \mathrm{BU})$. This reduction was sustained throughout the maintenance phase $(\mathrm{P}=0.04$ for $0.1 \mathrm{BU}$, and $\mathrm{P}=0.01$ for 1 and $10 \mathrm{BU})$.

Parker 1989

Immunotherapy resulted in no significant change in the immediate cutaneous response. However, the late cutaneous response was significantly reduced; actively treated mean versus placebo treated mean was $8.59 \mathrm{~cm}$ versus $33.37 \mathrm{~cm}$, respectively; $\mathrm{P}=0.0001$.

Pastorello 1992

A significant decrease $(P<0.02)$ in specific skin reactivity to the grass pollen extract was observed in actively treated patients after 4 and 12 months of immunotherapy; no differences were detected in the placebo group. No skin reactivity to histamine was detected in either group.

Tari 1997

Active treatment was associated with a significant reduction in the allergen/histamine wheal ratio, reflecting reduced skin sensitivity. During the course of the first year of treatment, the ratio decreased from a median value of 3.05 to $1.8(\mathrm{P}<0.01)$; and by the end of the second year, the ratio was further reduced to $1.0(P<0.01)$. In the placebo group there was no change during the first year, but at the end of the second year, after 1 year of therapy, the ratio was decreased significantly to $1.75(P<0.01)$.

Varney 1991

After immunotherapy there was a significant $(P=0.02)$ reduction of $40 \%$ in the immediate $(15$ minutes) skin reaction in the Alutard treated group (median difference $-7.5 \mathrm{~mm}$ ) compared with the placebo group (median difference $-3.5 \mathrm{~mm}$ ). A significant $(P<0.001)$ reduction of $57 \%$ was also found in the late (24 hours) skin response in the Alutard treated group (median difference -36.5 $\mathrm{mm}$ ) compared with the placebo group (median difference $+14.9 \mathrm{~mm}$ ).

Walker 2001

Both early $(P=0.007)$ and particularly late $(P=0.000)$ skin responses after intradermal allergen were markedly reduced after immunotherapy compared with placebo.

Zenner 1997

The threshold dose in skin prick test titration was higher in the actively treated group than in the placebo group at $T 1$. This was not significant $(P=0.09)$ for the total number of patients but was significant $(P=0.005)$ for patient who reached the maximum dose of 1000 SE during the injection phase. 
Table 14. Bronchial Challenge

\begin{tabular}{ll}
\hline Study & Result \\
\hline Armentia-Medina 1989 & $\begin{array}{l}\text { A significant decrease in specific }(\mathrm{P}<0.001) \text { and non-specific }(\mathrm{P}<0.05) \text { BHR to grass pollen was } \\
\text { found in treated patients compared to controls. }\end{array}$ \\
\hline Dolz 1996 & $\begin{array}{l}\text { Bronchial provocation test comparison of initial time (T0) and end time (T4), showed an increase of } \\
1000 \text { UB which was necessary to make the active group positive }(\mathrm{P}<0.001) . \text { There were no signifi- } \\
\text { cant differences in the placebo group. }\end{array}$ \\
\hline Ortolani 1984 & $\begin{array}{l}\text { The threshold of specific bronchial reactivity to provocation test PD 20\% FeV1 did not show any } \\
\text { variations either in patients who were treated with placebo or in those who received active anti- } \\
\text { gen. }\end{array}$ \\
\hline
\end{tabular}

WHAT'S NEW

\begin{tabular}{lll}
\hline Date & Event & Description \\
\hline 25 August 2008 & Amended & Converted to new review format. \\
\hline
\end{tabular}

\section{HISTORY}

Protocol first published: Issue 1, 2000

Review first published: Issue 1, 2007

\begin{tabular}{lll}
\hline Date & Event & Description \\
\hline 14 November 2006 & $\begin{array}{l}\text { New citation required and conclusions } \\
\text { have changed }\end{array}$ & Substantive amendment \\
\hline
\end{tabular}

\section{CONTRIBUTIONS OF AUTHORS}

MOISES CALDERON: Lead author, searching for trials, quality assessment of trials, design of data extraction form, data extraction, data analysis, input at all other stages of review.

BERNADETTE ALVES: Searching for trials, quality assessment of trials, design of data extraction form, data extraction, data analysis, input at all other stages of review.

MIKILA JACOBSON: Contribution to data analysis.

BRIAN HURWITZ: Contribution to development of protocol.

AZIZ SHEIKH: Conceiving the review, leading protocol development, searching for trials, input at all other stages of review and supervision of review process.

STEPHEN DURHAM: Protocol development, input at all other stages of review and supervision of review process.

\section{DECLARATIONS OF INTEREST}

The Department of Upper Respiratory Medicine, National Heart \& Lung Institute, London, UK, headed by Professor Durham, has received financial support from ALK-Abelló, Horsholm, Denmark - manufacturers of allergen extracts. 


\section{N DEX TERMS}

\section{Medical Subject Headings (MeSH)}

Allergens [*administration \& dosage]; Desensitization, Immunologic [adverse effects] [*methods]; Injections, Subcutaneous; Pollen [adverse effects] [immunology]; Randomized Controlled Trials as Topic; Rhinitis, Allergic, Seasonal [ therapy]

\section{MeSH check words}

Humans 